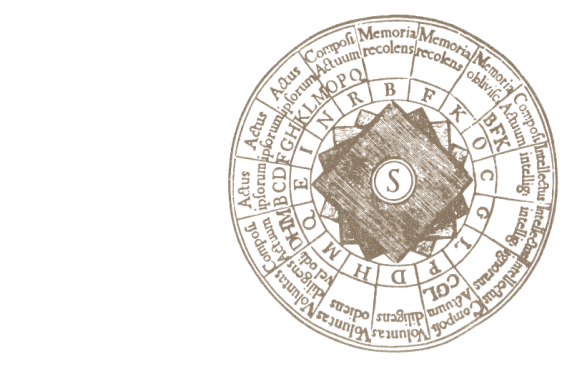

QUADERNS

VI : 2 



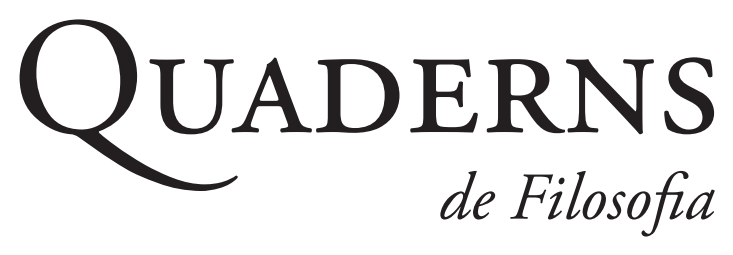

\author{
VOL. VI : 2 \\ VALÈNCIA, 2019
}

SOCIETAT DE FILOSOFIA DEL PAÍS VALENCIÀ 


\section{QUADERNS DE FILOSOFIA}

Director: Tobies Grimaltos (Universitat de València)

Secretari de redacció: Sergi Rosell (Universitat de València)

Consell de redacció: Ramón Feenstra (Universitat Jaume I), Elsa González Esteban

(Universitat Jaume I), Javier Gracia (Universitat de València), Eduardo Rivera López

(Universidad Torcuato di Tella), Pablo Rychter (Universitat de València),

Jennifer Saul (University of Sheffield), Faustino Oncina (Universitat de València), José Zalabardo (University College London)

Consell editorial: Jesús Alcolea (Universitat de València), Vicent Baggetto (IES Joan

Fuster de Sueca), Tyler Burge (UCLA), Enric Casaban (Universitat de València), Pascual Casany (València), Jesús Conill (Universitat de València), Adela Cortina (Universitat de València), Christine Chwaszcza (Universität zu Köln),

Antoni Defez (Universitat de Girona), Román de la Calle (Universitat de València), Vicente Domingo García Marzá (Universitat Jaume I), Manuel García-Carpintero (Universitat de Barcelona), Tomás Gil (Technische Universität Berlin), Susan Haack (University of Miami), Christopher Hookway (University of Sheffield), Joan Llinares (Universitat de València), Genoveva Martí (Universitat de Barcelona, ICREA), Carlos Pereda (UNAM), Fernando Miguel Pérez Herranz (Universitat d'Alacant), Giovanna Pinna (Università del Molise), Xavier Serra (IES Joan Fuster de Sueca), Sergio Sevilla (Universitat de València), Ernest Sosa (Rutgers University), Nicholas White (UC Irvine)

Edita: Societat de Filosofia del País Valencià eISSN: 234I-3042

Disseny i seguiment editorial: Antoni Domènech

Col.laborador en la correcció lingüistica: Guillem Llop

(C) de l'edició, Societat de Filosofia del País Valencià

(C) dels articles, els seus autors

http://ojs.uv.es/index.php/qfilosofia

Redacció: Societat de Filosofia del País Valencià

Universitat de València — Facultat de Filosofia i Ciències de l'Educació

Departament de Filosofia

Av. Blasco Ibáńez, 30-5a. 460 Io València

e-mail: sfpv@uv.es

http://www.uv.es/sfpv/ 
QuADERNS DE FILOSOFIA és una revista acadèmica dirigida als professionals de la filosofia de periodicitat semestral. Publica articles de temàtica filosòfica de qualitat científica i té un interès especial en la didàctica de la filosofia.

Cada número ordinari té tres parts: 1 . Articles d'investigació: contribucions originals pertanyents als diversos àmbits de la recerca filosòfica; 2. L'anomenada "Brúixola filosòfica", feta d'articles que presenten un determinat tema o debat filosòfic; i 3. Documents, entrevistes, notes de discussió i ressenyes.

Tots els articles originals són sotmesos a una revisió cega anònima per experts en l'àrea corresponent.

La revista es publica en versió electrònica d'accés obert (Open Journal System).

La revista és inclosa en alguns dels índexs de major prestigi internacional en filosofia i humanitats, com són ERIH PLUS, Latindex, ISOC, Dialnet, Philosopher's Index, DOAJ, EBSCO, REDIB, i el consell de redacció treballa per a la inclusió en d'altres, en especial SCOPUS, FECYT i CARHUS Plus+.

\section{Normes de publicació}

Els articles poden estar escrits en català, castellà i anglès, i no han d'excedir de les 10.000 paraules. Han de dur títol i incloure un resum (de fins a 150 paraules) i unes paraules clau en la llengua de l'article i en anglès. Els manuscrits s'han de presentar de forma anònima per tal de garantir-ne el dictamen cec; és responsabilitat de l'autor eliminar qualsevol autoreferència.

També es poden proposar ressenyes de llibres publicats en els darrers tres anys, amb una extensió màxima de 2.000 paraules, llevat de casos excepcionals prèviament acordats amb la direcció de la revista. Les ressenyes no tindran títol ni notes. Com a encapçalament cal consignar les dades completes del llibre ressenyat, inclòs l'ISBN. Cal recordar que una ressenya no és un resum, sinó un examen crític del llibre ressenyat.

Les normes d'estil poden consultar-se en la versió electrònica de la revista, però en tot cas sols s'exigirà el seu compliment en la versió final de l'article o ressenya, si se n'accepta la proposta. 



\section{ÍNDEX}

\section{Introducció}

"The Past and Future of Analytic Philosophy in Spain: XX Years

of Taller d'Investigació en Filosofia",

Marta Cabrera, Joan Gimeno-Simó and Saúl Pérez-González

(Universitat de València)

Articles

"Sherlock Holmes Is Not Out There: Some Ideas for

An Anti-Exoticist Account of Fictional Characters",

Jansan Favazzo (Università di Macerata) .................................... I

"Defining Life as a Non-Essentialist Natural Kind",

Jaime Soler PARra (UNED) .................................................... $\quad 27$

"The Egalitarian Quality of Lottocracy",

Julia JAKOBI (Universität Hamburg)

"¿Tiene cabida el justiciero en las sociedades democráticas?

Una respuesta desde el mundo del cómic",

Francisco FANdos Marí (UNED)

\section{Brúixola filosòfica}

"Semàntica i pragmàtica, contingut i context",

Joan Gimeno-Simó (Universitat de València)

Notes de discussió i ressenyes

"Los límites exteriores del capitalismo en la 'crítica de la economía política' de Marx. Sobre la interpretación de César Ruiz Sanjuán de la articulación de historia y sistema en Marx", Óscar Cubo (Universitat de València)

Matt Sleat (ed.) 2018, Politics Recovered: Realist Thought

in Theory and Practice.

Per Alberto Manuel Hers Martínez (Universiteit Leiden) 



\section{Introducció}



QUADERNS DE FILOSOFIA VOL. VI NÚM. 2 (20I9): I I-I 3

eISSN: 234I-3042 DOI: I0.7203/QFIA. 6.2.I605 I

Marta Cabrera, Joan Gimeno-Simó and Saúl Pérez-González

Universitat de València

\section{The Past and Future of Analytic Philosophy in Spain: XX Years of Taller d'Investigació en Filosofia}

$\mathrm{T}$

HE Taller d'Investigació en Filosofia is a graduate workshop in philosophy that every year brings together young scholars in order to promote the exchange of ideas with fellow philosophers working on various topics in different areas. Starting out as a local graduate workshop, it has over time attracted an increasingly wider audience, and by the time of its XX anniversary it has become a truly global event that gathers every year participants from all over the world.

The XX edition of the Taller d'Investigació en Filosofia began with an invited talk by Esa Díaz-León, a former participant in the workshop who is nowadays a prominent academic philosopher in Spain. Just like her, several other participants and organisers of previous editions took part in the event by sharing their experience in a round table commemorating its XX anniversary. The presence of these philosophers, currently lecturers and professors, underlines the relevance of this event for the development of analytic philosophy in our country, and for young philosophers who are pursuing a career in the academic world. The Taller d'Investigació en Filosofia has proven to be a place for them to share their ideas, get in contact with fellow researchers and improve their knowledge and skills.

This special issue brings together the work of several participants of the XX edition of the conference. The papers included here are an example of the high quality of the contributions, and they also reflect the interdisciplinary approach of the event, which covers areas from Philosophy of Science to Political Philosophy, as well as Metaphysics, Philosophy of Mind and Language, and Epistemology.

The article by Jansan Favazzo, entitled "Sherlock Holmes Is Not Out There: Some Ideas for A Non-Exoticist Account Of Fictional Characters", 
sets out to provide a semantics for proper names in fiction from the point of view of nominalism and anti-Meinongianism, i.e., without acknowledging the existence of any kind of abstracta. The strategy pursued in this paper is a variant of the Sellarsian metalinguistic account of abstract terms, which deals with statements like "modesty is a virtue" by paraphrasing them away as "all modestwords are virtue-words". Favazzo extends this strategy to fictional proper names: he proposes that their (secondary) extension be understood as a cluster of depictions made in accordance to a certain tradition, and that sentences like "Sherlock Holmes is a detective" be paraphrased away accordingly as "all Sherlock|Holmes-depictions are detective depictions". Throughout the paper Favazzo provides some hints as to how to understand the notions he employs, thus laying the foundations for future work. His discussion briefly covers issues such as the proper way to quantify over fictional characters, when to count a depiction as fictional, including fictional depictions of real characters such as Napoleon in War and Peace, and how to extend his analysis to metatextual statements such as "Sherlock Holmes is a famous character". In sum, the paper sets out a promising approach to the semantics of fictional proper names while at the same time getting rid of any kind of exotic ontological commitment.

Jaime Soler Parra's article, "Defining life as a non-essentialist natural kind", addresses the scepticism about the definition of life and explores the prospects of characterising life as a non-essentialist natural kind. During the last decades, many and diverse definitions of life have been proposed (e.g. physiological definitions, genetic definitions, thermodynamic definitions...). This multiplicity of proposals, and the inherent absence of consensus, have favoured the scepticism about the possibility of defining life. Sceptics argue that life can only be defined in a conventional sense, that defining life is either impossible or pointless, or that every type of life must be considered as an individual. After analysing sceptics' arguments, Soler claims that all of them are based on the same assumption, i.e., defining life requires identifying a basic essential property (or a set of basic essential properties). They are effective only if that requirement is assumed. Subsequently, after showing that sceptics' assumption does not suit scientists' practice, he explores the possibility of defining life in a non-essentialist way. Within this framework, most proposals have characterized life as a homeostatic natural kind. However, that approach has outstanding difficulties in accounting for life. Soler argues that a more promising strategy would be to define life as a promiscuous natural kind. Promiscuous natural kinds not only are compatible with the diffuse limits of the notion of life and the fact that kinds are not always defined in exactly the same way, they also account for scientists' use of the concept of life. In his article, Soler also discusses the relevance and utility of defining life for 
scientific research. He considers that it is useful for guiding scientific research and avoiding confusing results.

Finally, in "The Egalitarian Quality of Lottocracy", Julia Jakobi explores the way in which lottocratic systems, where politicians are randomly selected out of the totality of citizens entitled to vote, could satisfy the egalitarian requirement of democracy. There is broad consensus on the idea that democracy is the most desirable politic system available. Authors have argued for its value on the grounds of instrumental or egalitarian reasons: democratic decisionmaking tends to render good and epistemically valuable results and democracy is a source of political equality. The proponents of lottocratic models, however, claim that replacing the right to vote by the chance to be selected can satisfy both the epistemic and egalitarian values of democracy. Jakobi focuses on the latter and argues that, in addition to improving the representation of the population and reducing undemocratic influences, as some proponents have pointed out, having a chance to be selected by lot satisfies the intrinsic value of democracy in a relevant way. It does so by enhancing political justice and providing citizens with an equal chance on political influence. After examining the reasons why political equality is considered a key element of a desirable political system, Jakobi addresses two possible ways in which we can understand such notion. She holds that political equality can be conceived of as political justice and as vertical equality of influence, and provides arguments that show that a lottocratic system satisfies them both.

During the last two decades the Taller d'Investigació en Filosofia has served as a forum of discussion and exchange for the younger generations of academic philosophers in Spain. It has fueled the academic career of many former participants who have seen their work published as a result of the valuable feedback and new ideas they received. We hope that this workshop will continue to perform such significant role for future generations in philosophy to come.

\section{Acknowledgments}

Marta Cabrera is supported by the Spanish Ministry of Science, Innovation and Universities under grants BES-2017-081537 and FFI201675323-P. Joan Gimeno-Simó is supported by the European Social Fund and the Conselleria d'Educació of the Valencian Community under the grant ACIF/2016/421. Saúl Pérez-González is supported by the Spanish Ministry of Science, Innovation and Universities under grants FPU16/03274 and FFI2017-89639-P. 

Articles 

QUADERNS DE FILOSOFIA VOL. VI NÚM. 2 (2019): I7-25

eISSN: $234 \mathrm{I}-3042$ DOI: I0.7203/QFIA. 6.2.I 6052

JANSAN FAVAZZO

Università di Macerata

\title{
Sherlock Holmes Is Not Out There: Some Ideas for An Anti-Exoticist Account of Fictional Characters
}

Received: 15/7/19. Accepted: 11/8/19

\begin{abstract}
Many philosophers include fictional objects like Sherlock Holmes in their ontological inventory. Yet, if Sherlock Holmes is part of reality, then he must be an "exotic" entity: either non-concrete or non-actual or non-existent. In this paper, I will assume that whatever there is (in reality) is concrete, actual, and existent. Accordingly, I will sketch a way to get rid of fictional entities, based on Sellars' metalinguistic strategy for nominalism. Roughly speaking, the main result can be stated as follows: when we talk about Sherlock Holmes, we are actually talking about Sherlock Holmes depictions.
\end{abstract}

Keywords: fiction, nominalism, actualism.

\section{A BRIEF INTRODUCTION}

Fictional discourse posits some serious troubles for the metaphysician. 1 What are we talking about when we utter (true) sentences like 'Sherlock Holmes is a detective' or 'Sherlock Holmes was created by A. C. Doyle'? Are we ontologically committed to such an entity as Sherlock Holmes, namely to an object denoted by the proper name 'Sherlock Holmes'? I will distinguish two main different issues related to this kind of questions. The first one concerns the semantic value of fictional proper names: ${ }^{1}$ (i) does a fic-

${ }^{1}$ It should be clear that I am talking about purely fictional proper names, like 'Sherlock Holmes' and 'Mrs Dalloway'; real proper names that happen to occur in works of fiction, like 'Napoleon' in War and Peace, are not purely fictional in this sense. Unless otherwise specified, I will talk of fictional names in the sense of purely fictional names. 
tional proper name refer to a (fictional) object? The second one concerns the structure of reality: (ii) should fictional objects be included in the inventory of what there is? A fictional realist is a philosopher who answers affirmatively both to (i) and (ii).

In the last decades, fictional realists have furnished several different metaphysical accounts of fictional objects. They all agree that, even if one could travel back in time and reach London in the 1890s, she would not find any detective named Sherlock Holmes at 221B Baker Street. As a matter of fact - realist $A$ will argue - detectives are concrete entities (i.e., located in space-time) while Sherlock Holmes is an abstract entity; more precisely, it is an abstract artefact created by some human being in flesh and blood. ${ }^{2}$ Realist $B$ would then point out that Sherlock Holmes is not abstract at all: for instance, he smokes the pipe and plays the violin - both activities of a kind that only concrete entities are able to perform; the reason why we could not find him, here in the actual world, is that he is a concrete inhabitant of some merely possible world. ${ }^{3}$ Finally, realist $C$ will provide a further explanation: Sherlock Holmes may be abstract or concrete, actual or merely possible (and even impossible!), but what really matters is that he lacks the property of existence, more or less as I lack the property of being two metres tall. ${ }^{4}$

In short, three different options are available for the fictional realist. This conceptual pattern may be summarised by means of the following conditional:

(EX) If Sherlock Holmes is part of reality, then he is either non-concrete or non-actual or non-existent.

In other words, were Sherlock Holmes out there, it/he would be an "exotic" entity. ${ }^{5}$ In what follows, I shall argue that Sherlock Holmes is not out there, since I want to endorse (and defend) a metaphysical view according to which there are no exotic entities. Anti-exoticism, as a motivation for fictional anti-realism, comes at a price: in order to keep our inventory as simple as possible, the semantic analysis of certain ordinary discourses has to be slightly complicated. I believe that, other things being equal, it is a better choice to complicate semantics rather than ontology.

${ }^{2}$ The artefactualist view is championed by (among others) Van Inwagen (I977), Thomasson (1999), and Voltolini (2006).

${ }^{3}$ Lewis (1978) may be taken to be a supporter of the possibilist view, but there are good reasons to doubt it: cf. Sainsbury (2010, 82-3).

${ }^{4}$ Neo-Meinongian accounts of fictional characters are, among others, Parsons (I980), Zalta (1983), Castañeda (1989), and Priest (2005).

${ }^{5}$ I borrow this use of the term "exotic" from Sainsbury (2010, 32). 


\section{Nominalism and Actualism}

Anti-exoticism can be characterised as a combination of actualism and nominalism, namely as the conjunction of the following three theses:

1. Everything exists;

2. Whatever exists is actual;

3. Whatever exists is concrete (i.e., located in space-time).

Actualism, broadly conceived, corresponds to theses (1) and (2): there are no objects that do not exist and there are no merely possible objects, respectively. ${ }^{6}$ Thesis (3) is meant to capture nominalism. We should be quite cautious here, since this ancient label has taken on slightly different meanings over the centuries. Thus, let me clarify a little bit further what I mean by (3).

In a rather traditional sense, nominalism amounts to the exclusion of universals from the ontological inventory; nowadays, philosophers use this word to intend the rejection of abstract objects as well. These two kinds of nominalism are certainly independent from each other, in so far as one could either reject universals but accept other abstracta (e.g., numbers or sets) or reject abstract entities but deny altogether that universals are really abstract. I suggest (3) as a good way to summarise both varieties of nominalism, since the characterisation of universals as non-concrete entities sounds much more plausible to me. However, for the purposes of this paper, it is sufficient to characterise nominalism as the rejection of abstract objects.

The picture of reality that results from the conjunction of (1), (2), and (3), is that of a universe populated only by concrete entities, which are both actual and existent. It seems to me that this sort of anti-exoticist picture has two main advantages over its rivals. In the first place, it may seem to fit better a "naturalistic" attitude towards reality: ${ }^{7}$ exotic entities would be (by definition) causally isolated from the (actual) spatio-temporal world; as a consequence, it looks quite mysterious how they could play any substantial explanatory role in our theories about reality, or how we could even get to know anything about them. To be sure, exoticist metaphysicians have their own ways out of this kind of troubles; yet, if there is a way to get rid of exoticist explanations altogether, it may be worth pursuing it. Secondly, an anti-exoticist inventory promises to be more parsimonious than an exoticist one. If we have to choose between two theories with equal explanatory power and unequal ontological commitments, it is reasonable to apply Ockham's razor and choose the less committing one.

In the rest of this paper, I will focus on two specific categories of exotic entities: universals (with a special focus on properties) and fictional objects.

${ }^{6}$ I use "object" (like "entity" above) as a blanket term.

${ }^{7}$ Here, "naturalism" should be interpreted in a very broad sense. 
Let us begin with the former category. Realism about properties (and relations) is typically motivated on the grounds that it provides a simple explanation to a couple of widespread phenomena: predication (i.e., the fact that a certain predicate correctly applies to a certain thing, as in the true sentence 'Socrates is a philosopher'); similarity between things (e.g., the fact that two different roses have the same colour). According to the realist, a sentence like

(J) John is modest

is true in so far as there is a certain property, namely modesty, that the individual denoted by the proper name 'John' exemplifies. So it seems that, in order to account for the truth of simple atomic sentences like (J), we need to posit an exotic entity in virtue of which something is such and such. On the contrary, a nominalistic explanation may go as follows: (J) is true because John is such and such, and we need no further entity in virtue of which John is such and such. ${ }^{8}$ In other words, predication and similarity are taken to be fundamental facts, which require no further explanation - not even the realist's one, that simply consists of postulating the existence of mysterious entities, eternal and immutable inhabitants of a mysterious Platonic realm. ${ }^{9}$ The core idea behind this view is that explanations have to stop at some point: and what better point than a fundamental fact? ${ }^{10}$

So far so good. Still, there is a third phenomenon that seems to motivate realism about universals. I am thinking of abstract reference, which has proved far more resistant to nominalistic approaches. Let us consider, for instance, a sentence like

(M) Modesty is a virtue.

Apparently, by uttering (M), we are referring to a (first-order) property, namely modesty, in order to ascribe the (second-order) property of being a virtue to it: when someone asserts $(\mathrm{M})$, she seems to be committed to the existence of exotic entities. At first, the nominalist may attempt to analyse such tricky cases by pointing out that $(\mathrm{M})$ does not really concern abstract universals but only concrete particulars (more specifically, persons). Accordingly, (M) should be paraphrased away as

(P) All modest persons are virtuous persons.

Unfortunately, this strategy does not work. It is easy to verify that (M) and $(\mathrm{P})$ have different truth conditions. Just imagine that John is actually modest yet he lacks any other virtue, so that nobody would say of John that he is virtuous: that is a scenario in which $(\mathrm{M})$ is true and $(\mathrm{P})$ is false.

${ }^{8}$ The same holds, mutatis mutandis, for sentences like 'Rose 1 and rose 2 share the same colour', which are supposed to reflect in natural language the phenomenon of similarity.

${ }^{9}$ For a detailed overview of the debate about universals in contemporary philosophy, cf. Loux (2017, 17-81).

${ }^{10}$ Cf. Devitt (1980, 436). 


\section{Sellars' Strategy Generalised}

A much more promising strategy for nominalism was developed by Sellars (1963), along the lines suggested by Carnap (1959). In $\$ 2.1$, I will present a simplified version of this strategy (in fact, I will ignore a problem about translation, which Sellars solves by improving the notational system, because it is not relevant to our purposes). Then, in $\$ 2.2$, I will show that Sellars' strategy can be straightforwardly generalised in order to analyse fictional discourse as well.

\subsection{How To Dispose of Universals}

Let us consider (M) again. At first glance, as we just underlined, (M) seems to concern merely extra-linguistic entities (i.e., abstracta like properties or concreta like persons). But maybe it simply concerns linguistic entities like words (and, more specifically, predicates): it seems reasonable to analyse sentences like $(\mathrm{M})$ as concerning language itself rather than (extra-linguistic) reality. For instance, $(\mathrm{M})$ may be paraphrased away as follows:

(W) 'Modest' is a virtue-word,

where 'virtue-word' (or 'virtue-predicate', for that matter) could be seen as a mere label which allows us to record certain linguistic conventions of the community we belong to. Clearly enough, these conventions are not arbitrary in so far as they actually reflect some objective facts about reality (after all, our nominalist is not meant to be a radical one): for instance, the (fundamental) fact that there are certain similarities among different objects (so that people happen to gather them all under the label 'modest' or 'modesty'), and the (equally fundamental) fact that there are (second-order) similarities among different clusters of objects (e.g., modest objects, courageous objects, etc., so that people happen to gather them all under the label 'virtue' or 'virtuous').

However, it should be clear that the nominalist cannot treat 'modest', in (W), as a singular term referring to a word type: otherwise, her efforts against universals (or exotic entities in general) would be neutralised all of a sudden. ${ }^{11}$ Thus, she has to point out that (W) does not concern word types but only word tokens - particular modest-inscriptions or modest-utterances. Therefore, $(\mathrm{M})$ is better paraphrased away as

$\left(W^{*}\right)$ All modest-words are virtue-words.

More precisely, all modest-words compliant with a certain linguistic tradition (namely, canonical English) are virtue-words (compliant with that tradi-

${ }^{11}$ It is controversial whether types should be conceived as universals or not (see Wetzel (2018, $\$ 3$ ). Anyway, they would not satisfy the anti-exoticist requirements outlined in (1), (2), and (3). 
tion). ( $\left.\mathrm{W}^{*}\right)$ can be used as a paradigm for systematic nominalistic paraphrase of our ordinary talk about properties (and relations). In what follows, I will propose that we naturally extend this kind of analysis in order to account for our ordinary talk about fictional characters as well. For this purpose, it is required to widen our focus from words and linguistic practices to depictions and representational practices in general.

\subsection{How To Dispose of Fictional Objects}

Sellars' metalinguistic strategy for ordinary talk of universals is widely recognised as the most successful one. It seems to me that the analogy with the case of fictional discourse is quite straightforward. People use sentences like (M) in order to record (and convey) certain linguistic conventions; in the same way, people use sentences like

(S) Sherlock Holmes is a detective

in order to record (and convey) certain narrative - and, more generally, depictive - conventions. Accordingly, (S) should be paraphrased away as

$\left(S^{*}\right)$ All Sherlock|Holmes-depictions are detective-depictions. ${ }^{12}$

More precisely, all Sherlock|Holmes-depictions compliant with a certain depictive tradition are detective-depictions (compliant with that tradition). As a matter of fact, we can trace back the very beginning of the relevant tradition, so identifying the human being who initiated it (namely Sir A. C. Doyle). By the way, this is what the artefactualist actually talks about when she claims (by means of a powerful metaphor) that Sherlock Holmes was created by A. C. Doyle.

\section{Fictional Characters As (Clusters of) Fictional Depictions}

What has A. C. Doyle really done, then? I suggest that, instead of having created (or, even worse, discovered) an exotic entity, he simply manufactured (both mentally and materially) the first Sherlock|Holmes-depictions ever. Thus, when we talk (or think) about Sherlock Holmes, we simply talk (or think) about Sherlock|Holmes-depictions - i.e., fictional depictions produced within a certain depictive tradition. In other words, we use the fictional proper name 'Sherlock Holmes' in order to convey some information about a specific cluster of fictional depictions (e.g., that each member of the relevant cluster is a detective-depiction). Besides, when we quantify over fictional characters, as in the well-known Van Inwagen's sentence

\footnotetext{
${ }^{12}$ I use the symbol "|" just to separate different words.
} 
(V) There are characters in some $19^{\text {th }}$ century novels who are presented with a greater wealth of physical detail than is any character in any $18^{\text {th }}$ century novel, ${ }^{13}$

we actually quantify over clusters (or pluralities) of fictional depictions: after all, as I want to suggest, fictional characters are nothing but these clusters (or pluralities) of fictional depictions. ${ }^{14}$

Therefore, let me clarify a little bit further what exactly I mean by "depiction" and in which cases a depiction ought to be taken as a fictional one. First of all, I call depiction anything that is supposed to depict or represent something else (sometimes, so to speak, things that do not exist), without any restriction on the kind of language (verbal or not) and of medium (mental or material) employed. Accordingly, drawings and paintings, verbal descriptions and narrations (like those occurring in Doyle's stories or in my mind right now), films, and even purely instrumental musical compositions, count as good examples of depictions in this very broad sense. At this point, we still need a criterion that allows us to distinguish between fictional and nonfictional ones.

As is well known, Tolstoj's War and Peace is a work of fiction in which both Bezuchov (a purely fictional character) and Napoleon (a historical figure) are depicted. Intuitively, though, one would say that Tolstoj's Bezuchov-depictions are as fictional as Tolstoj's Napoleon-depictions: they both belong to a work of fiction; one would not say of an "inaccurate" Napoleon-depiction that it is false, she would just say that it is fictional (hence, not supposed to be true or false simpliciter). As a rough approximation, the criterion we are looking for could thus be stated as follows:

(C) A depiction $D$ is fictional only if either $D$ is not meant to depict an existent object or D is not meant to depict an existent object in a truthful way.

The disjunction in (C) is supposed to account for the intuition that there can be fictional depictions both of fictional characters and of real persons (or objects whatsoever). Still, the condition expressed in (C) is not a sufficient one: there can be cases in which the condition is fulfilled for a depiction $D$, yet $D$ is not fictional but rather mendacious. For instance, lies and deceits are depictions of this sort. On the contrary, the kind of fiction we are talking about is always declared, given that its purpose is not to deceive people but to entertain them. ${ }^{15}$ Also, the author of a work of fiction may happen to produce, by pure coincidence, truthful depictions of existent objects (like individuals, states of affairs, and so on); still, as our criterion assures us, they would count as fictional, since

${ }^{13}$ Van Inwagen (1977, 302).

${ }^{14}$ As in the case of words, it should be clear that we are talking about depiction tokens.

${ }^{15}$ Cf. Walton (I990) for a comprehensive account of fictional practices as games of makebelieve. 
the author did actually mean to create fictional depictions. After all, it seems that knowledge of the author's intentions is enough to decide whether a depiction is fictional or not.

So far, then, I have just sketched a way to get rid of a special category of exotic objects, namely fictional objects. Unfortunately, $\left(S^{*}\right)$ above does not work as a general paradigm for systematic anti-exoticist paraphrase of our ordinary talk about fictional characters. As a matter of fact, it only works for a specific subclass of fictional sentences: those which convey information about what is true inside the relevant stories. On the contrary, fictional sentences that convey information about what is true outside of the stories, like

(F) Sherlock Holmes is famous,

do need a slighlty different treatment. In fact, while (F) seems true, it does not seem true that all Sherlock|Holmes-depictions are famous (it seems that they are collectively famous). In order to analyse external fictional discourse, some further tool is actually needed.

However, the core idea still holds: even in the case of (F), we use the fictional proper name 'Sherlock Holmes' in order to talk about a certain cluster of fictional depictions. In particular, we say of this cluster that its members are collectively famous - more or less as we say of an orchestra that it is famous, even if not every member of the orchestra is famous. In other words, it seems that we can account for the intelligibility of fictional proper names by taking the relevant clusters of fictional depictions as their semantic values. ${ }^{16} \mathrm{I}$ believe that, along this path, it is possible to provide a complete analysis of fictional discourse which requires no exotic entity in the ontological inventory. At the same time, this kind of analysis would represent a good alternative to the most widespread variety of fictional anti-realism (i.e., fictionalism about fictional characters), ${ }^{17}$ since it does not need to assume that people are involved in some sort of pretense when they utter sentences like (F): they actually talk about something, namely (clusters of) fictional depictions.

\section{Acknowledgments}

I wish to thank Francesco Orilia and an anonymous reviewer for their helpful comments on a previous draft of this paper.

${ }^{16}$ More precisely, the relevant cluster of fictional depictions would be a secondary extension (as GoODMAN 1949 would call it) of a fictional proper name, while its primary extension (namely its referent) would be just empty. I will not go into this now, since it falls outside the scope of this paper.

${ }^{17}$ Cf., among others, Walton (1990), Brock (2002), and Everett (2013). 


\section{REFERENCES}

Armstrong, D. 1997, A World of States of Affairs, Cambridge: Cambridge University Press.

Brock, S. 2002, "Fictionalism about Fictional Characters", Nồs, 36 (1): 1-21.

Carnap, R. 1959, The Logical Syntax of Language, Paterson: Littlefield.

Castañeda, H. N. I989, Thinking, Language and Experience, Minneapolis:

University of Minnesota Press.

Devitt, M. I980, “'Ostrich Nominalism' or 'Mirage Realism'?”, Pacific Philosophical Quarterly, 61: 433-9.

Everett, A. 2013, The Nonexistent, Oxford: Oxford University Press.

Goodman, N. I949, "On Likeness of Meaning”, Analysis, 10 (1): 1-7.

Lewis, D. K. I978, "Truth in Fiction”, American Philosophical Quarterly, 15 (1): $37-46$.

Loux, M. 2017 ( $4^{\text {th }}$ edition), Metaphysics: A Contemporary Introduction, New York: Routledge.

Parsons, T. I980, Nonexistent Objects, New Haven: Yale University Press.

Priest, G. 2005, Towards Non-Being. The Logic and Metaphysics of Intentionality, Oxford: Oxford University Press.

Sainsbury, M. 2010, Fiction and Fictionalism, London: Routledge.

Sellars, W. I963, "Abstract Entities”, Review of Metaphysics, 16 (4): 627-71

Thomasson, A. I999, Fiction and Metaphysics, Cambridge: Cambridge University Press.

Van Inwagen, P. I977, "Creatures of Fiction", American Philosophical Quarterly, 14: 299-308.

Voltolini, A. 2006, How Ficta Follow Fiction. A Syncretistic Account of Fictional Entities, Dordrecht: Springer.

Walton, K. I990, Mimesis as Make-Believe: On the Foundations of the Representational Arts, Cambridge (MA): Harvard University Press.

Wetzel, L. 2018, "Types and Tokens", The Stanford Encyclopedia of Philosophy, $<$ https://plato.stanford.edu/archives/fall2018/entries/types-tokens/>.

Zalta, E. 1983, Abstract Objects: an Introduction to Axiomatic Metaphysics, Dordrecht: Reidel. 

QUADERNS DE FILOSOFIA VOL. VI NÚM. 2 (20I9): 27-4I

eISSN: $234 \mathrm{I}-3042$ DOI: I O.7203/QFIA. 6.2.I 6053

JAIME Soler PARRA

$U N E D$

\section{Defining life as a non-essentialist natural kind}

Received: 15/7/19. Accepted: 31/7/19

Abstract: The increasing number of proposals to define the concept of life in biology has led some authors to consider this task useless and without sense. All sceptics base their argument on the idea that life is a natural kind with a strong metaphysical commitment. Considering this, the aim of this paper is to explore the concept of life as a non-essentialist natural kind. It is intended to highlight that complex scientific concepts are better understood from points of view that are not constrained by the rigid frameworks of essentialism and the realism/conventionalism dichotomy.

Keywords: natural kind, definition of life, essentialism, operational definitions.

\section{INTRODUCTION}

T N I 976 two landers, part of the Viking program, touched down the Martian surface. One of its goals was to find indications of biological activity on the red planet, for which they had a series of experiments aimed at finding such signs. The interpretation of the results was quite complex, although at first they were considered negatively. Since then, the development of astrobiology and other new biological disciplines has been constantly increasing. As a result, some doubts about how to interpret the Viking experiments and other similar researches have emerged. To the extent that astrobiology and other new disciplines move within the limits of traditional biology, it is understandable that the interest in defining the concept of life has increased.

In this sense, Trifonov (201 I) and Diéguez (2013) take as reference the work of Popa (2004), who collects almost one hundred different proposals of 
the concept of life. It is also interesting to notice that one third of the proposals correspond to the year 2002, the last considered by Popa. Therefore, to get an idea of the complete picture, we must add the proposals that have emerged since 2002. Simply as a sample, point out the contributions of Gánti (2003), Ruiz-Mirazo, Peretó and Moreno (2004), Benner (2010), Damiano and Luisi (2010), Tsokolov (2010), Trifonov (20 I I), Diéguez (2008; 2013), Razeto-Barry and Ramos-Jiliberto (2013), Luisi (2015), Hermida (2016), Ferreira and Umerez (2018), or Smith (20 I 8). The number of different proposals, as can be seen, far exceeds one hundred.

Of course, it is possible to consider this huge quantity of proposals in a more limited number of types of definitions. One well-known classification was proposed by Sagan (1970), who considers physiological, metabolic, biochemical, genetic and thermodynamic definitions. More recently, authors such as Tirard, Morange and Lazcano (2010), as well as Smith (2018), have classified definitions of life as thermodynamic definitions, self-regulation definitions, and evolutionary ones.

On the other hand, new approaches (e.g. hybrid theories, analysis of life vocabulary) try to overcome the difficulties derived from the large number of proposals. But neither analysis of life vocabulary nor hybrid proposals elicit a sufficient consensus. Regarding the former, there are some important objections to their basic thesis ${ }^{1}$. Perhaps one of the most promising ways of research are hybrid proposals, which consider different types of properties related through complex phenomena. Nevertheless, as Ruiz-Mirazo, Peretó and Moreno (2002) show, hybrid theories are still far from solving may of the relevant questions regarding what life is.

Precisely, it is the large number of different proposals, and the difficulty to find a minimum denominator among them, which has favoured the scepticism of some authors. In relation to the difficulty to find an essential property of the concept of life, other questions related to the concept of life remain unresolved: the diffuse boundary between living and non-living entities (DuPRÉ and O'MALLEY 2009), the different assumptions of distinct disciplines (Ruiz Mirazo, Peretó and Moreno 2004; Machery 20 i2), the complexity of the processes involved (Popa 2004), or our limited knowledge about different types of life (CLELAND 2002).

Of course, scepticism is not always expressed in the same way. For instance, some authors conclude that life is a human kind (KeLler 2002), whereas other consider life as an individual (Mariscal and Doolittle 20 i 8). Howothers.

${ }^{1}$ See the criticism by Popa (2012) or Bor Luen Tan (2012), to Trifonov (20II), among 
ever, all sceptics share a common idea, that is, to define life is to find a basic essential property (or a set of essential properties). But is it possible to define life considering a different way? In this vein, some authors as Diéguez (2008; 20I3), and more recently Ferreira and Umerez (20I8), have explored some alternatives based on the ideas of homeostatic kinds and relevant stability.

Bearing this in mind, the first goal is to show that criticisms to define of life expressed by Keller, Cleland and Chyba and other authors are valid only for essentialist definitions, that is, they assume that to define life is to consider it as essentialist natural kind (section 2). Secondly, to show that researchers, in their practices, do not use essentialist definitions, but operational ones (section 3). In section 4, life will be considered as a non-essentialist natural kind, pointing out different ways in which this can be done. For this, different types of theories (Diéguez, Ferreira and Umerez, Dupré) will be considered. Finally, it is intended to highlight that complex scientific concepts are better understood from points of view that are not constrained by the rigid frameworks of essentialist natural kinds and the realism/conventionalism dichotomy (Putnam, 1988). It will also show to what extent this limitation could be overcome by non-essentialist proposals.

\section{ObJections to the POSSIBILITY OF DEFINING THE CONCEPT OF LIFE}

As noted above, nowadays skepticism about the possibility of defining life is increasing. Although not all skeptics share the same argument, all share the criticism regarding the possibility of defining life as a natural kind in a strong metaphysical sense. But research is far from finding an essential property to define life (or some essential properties). Without these properties, the kind has no clear limits, so it is only possible to delimit it in a conventional sense.

Thus, the large number of definitions about the concept of life is the result of a wrong metaphysic commitment. The issue has no solution, because life is not a natural kind, but other type of entity (an individual or a conventional kind). It is possible to find these or similar ideas in Keller (2002), Tirard, Morange and Lazcano (2010), Machery (2012), Cleland (2002; 20II) and Mariscal and Doolittle (2018).

According to Keller (2002), it is possible to define life, but only in a conventional sense. Keller suggests that the demarcation between life and nonlife is an historical and cultural issue. In fact, before the nineteenth century, the opposite of living was not inorganic, but dead. Keller considers that the current situation with respect to definitions shows that life is not a natural kind, but a conventional one. Thus, it is defined by the interests and values 
of human beings, and this also explains why there is no minimum consensus on necessary properties. To define life becomes an historical and social issue, rather than a scientific one.

Tirard, Morange and Lazcano (20 10) try to move the focus of attention. If defining the concept of life has not yielded fruitful results, it may be more interesting to shift the question to how the associated characteristics of life are acquired. This means treating life as an empirical and historical concept. So it is only possible to consider the concept of life within a conceptual framework, rather than by a precise definition.

Machery (2010) is also critical of the possibility of defining the concept of life. From his point of view, life can be understood as a folk concept or as a scientific concept. Modern research on folk concepts does not consider them as definitions, so if life were a folk concept, it would not be definable. Therefore, to be definable it should be considered as a scientific concept. It is possible to do this, and in fact different disciplines use distinct definitions. The problem is that each discipline considers the concept of life in a different way. If they do not agree on what is the essential property (or properties) of life, a general definition cannot be found. So to define life is not possible (considering folk concepts) or it is pointless (as a scientific concept).

Cleland (2012) expresses its reluctance considering different objections. The first is the confusion between linguistic entities and the epistemic ones. Thus, definitions refer to the way that speakers use terms, that is, to define is a linguistic issue. But when scientists use the concept life, they are interested in what really life is, not how speakers use this term. From a rather exhaustive study of the theories of reference, Cleland assumes the position defended by semantic externalism. This leads her to defend that concepts as water (and life) are not stipulations. In addition, Cleland considers that definitions of these type of concepts can only make sense within a broader theoretical framework. Therefore, concepts such as water, only has sense in a more general molecular theory. Similarly, the concept of life only makes sense within a more general theoretical context about biology.

A second criticism considers our limitations on the knowledge of different types of life. If as it seems according to different theories, all current organisms are descended from a common ancestor (LUCA), then we only know one type of life. Defining a kind from only one example results, at the very least, risky. The situation is similar to define mammals by only knowing zebras. Although stripes are common to all of them, the presence of mammary glands is much more determinant, even if only one half of the individuals possesses them.

Finally, Mariscal and Doolittle (2018), in a recent paper, consider life in as an individual. This idea is not new, and some authors has considered life on 
Earth as an individual (for instance, Hermida 20I6). But according to Hermida, life on Earth can be understood as an instance of a more general kind, whereas Mariscal and Doolittle reject this idea. According to them, every type of life is an individual, so it would be more accurate to say that each type of life is Life, with capital letters. It could be possible to find some common properties in different Lifes (for instance, among life in different planets, or between Life on Earth and synthetic Life). But such groupings respond to the epistemic needs of researchers, not to any ontological priority.

As can be seen, criticisms and arguments to reject a possible definition are very different in distinct authors. But all of them assume that to define life is to consider it as an essentialist natural kind. According with this idea, natural kinds are associated with a(some) necessary(ies) and sufficient property(ies). The intense debates about whether what defines life is the capacity to evolve, to selfregulate or both respond to the need to find such properties. There is a strong metaphysical commitment, so natural kinds are real and independent of human beings. Usually that independence is ensured through causal mechanisms.

On the other hand, according to this essentialist view, the demarcation of natural kinds is given by properties univocally considered, so there are no intermediate cases between the living and the non-living. A paradigmatic example of this is the definition of life as an autopoietic system given by Maturana and Varela (1973), especially in its first formulations. In this case, the systems are autopoietic or not, but it does not make sense to consider partially autopoietic systems.

As a consequence, to define life in an essentialist sense is to fix the concept one for all, according to some properties independent from human beings. So according to this view, we need more research in order to find the basic essences of life. Nevertheless, as critical authors highlight, it is difficult to defend that life is a natural kind if it must satisfy these strict requirements. So their criticisms works well considering natural kinds in this strong metaphysical sense. However, this debate can be considered from a different perspective, that is, asking if essentialist definitions are really used by scientists, or not. It is also interesting to ask whether these criticisms are valid for other ways of understanding natural kinds.

\section{USEFULNESS OF DEFINING THE CONCEPT OF LIFE}

In the previous section it has explained that criticisms about the possibility to define life work well considering definitions as essentialist natural kinds. But as Bich and Green (2017) show, scientists use definitions in an 
instrumental, open and flexible way. They call these definitions "operational definitions". Nevertheless, it is justified to ask what is the real way used by researchers to define life. In this section, it will be explained why the benefits of using instrumental definitions of life in a non-essentialist way may be greater than their risks.

As Bich and Green show, definitions can guide research through feedback processes. Scientists use definitions in an instrumental sense, starting with provisional theoretical definitions. Those definitions are used in order to guide research and design experiments according to them. The results of these experiments are used to reconsider the original definition, and change it if necessary, "definitions are exploratory tools that can change over time and across research programs" (14). Then this feedback process starts again. Bich and Green show this process through Luisi's research.

Luisi (1998) started his research with an autopoietic conception of life. This first definition served as a guide for its subsequent research, in an open and revisable way. Based on this theoretical model, Luisi and his team designed experiments that improved the understanding of different aspects of cell membranes, not well-known until that moment. As a result, they introduced changes in the theoretical model, allowing the development of new lines of research. For example, in 2006 and 2009 Luisi explicitly included references to the medium in his definition of life. On the other hand, since 2006 Luisi and his team seem to consider the limit of life in a non-essentialist sense, at least in the context of minimal cells, "clearly, the term minimal cell depicts large families of possibilities and not simply one particular construct" (272). Both modifications change significantly the original definition, and cannot be understood in the context of essentialist definitions.

Moreover, not defining concepts could be problematic. The research carried out by the Viking program show this clearly, due to the absence of a scientific definition of life. As Benner (2010) shows, there were experiments with both negative and positive results, but the final conclusion was negative. It seems clear that in this case the negative evidence had a greater weight. Such conclusion was linked to certain unspecified assumptions, namely, that life must be understood as life-on-Earth, at least in a metabolic sense. As those assumptions were not explicitly specified, researchers tried to respond to the conflicting results reinterpreting the positive ones. Of course, there was another possibility, that is, not to reinterpret the result, but assumptions about life. However, this only has sense if those assumptions, that is, the definition of life considered, is explicitly formulated.

This shows an important aspect. Even when explicit definitions are not formulated, researchers have certain beliefs about the concepts they work with. 
Some questions arise if definitions are assumed implicitly. How to properly assess a concept if it is not defined? According to what criteria? It is possible to change an implicit definition considering empirical research? If were possible, how to do this? As it happened in Viking experiments, not having explicit definitions could lead researchers to confusing, even mistaken, situations.

Defining the concept of life is also relevant in order to delimit the fields of research, and thus, the possible pertinent investigations in different disciplines. In the research on the origin of life on Earth, it seems obvious to take as a starting assumption that life is based on carbon, and the presence of water is essential for life (on the possibility of alternative forms of life on Earth, see Cleland and Copley 2005). However, in other disciplines such as astrobiology, it is not only possible, but even pertinent, to explore other options.

To see this, it is interesting to show some theories about these alternative options. Beyond the debate on whether or not life can be based on other material components such as silicon, authors such as Benner, Alonso and Carrigan (2004) explain how ammonia could play a water-like role, "metabolism in liquid ammonia is easily conceivable" (170). In the same vein, sulfuric acid can be a suitable solvent for life processes "sulfuric acid is a reasonably good solvent that supports chemical reactivity" (171). Of course, other authors like Pace (200I) believe that life beyond Earth must be materially similar to life on it. On the other hand, as Lange (I996) and other authors show, in artificial life it is common to consider the concept of life without a specific material support. Although this idea is especially popular in artificial life, it is possible to find it in other disciplines, as Popa (2004) shows.

The previous examples show how different disciplines use distinct assumptions regarding the concept of life. As already explained in the previous section, this has been criticized by Machery, who concludes that worrying about the concept of life is something pointless. However, far from it, here it is defended that defining the concept of life is useful both positively and negatively. Positively because definitions can guide scientific research in an open and feedback way, and according to new discoveries. Negatively, because as the example of the Vicking program shows, if the concepts used are not sufficiently defined, research could lead to confusing results.

\section{LIFE AS A NON-ESSENTIALIST NATURAL KIND CONCEPT}

At this point, it seems clear that it is difficult to define life as natural kind in a strong metaphysical sense. On the other hand, it is useful to define this concept. Bearing this in mind, how to reconcile both ideas? 
The solution can be found considering other types of natural kinds. As other debates in biology, such as species, there are other ways of considering natural kinds. The first of these possibilities was explored by Diéguez (2008; 2013), who shows that it is possible to consider life as a homeostatic natural kind. According to this concept, the presence of one or more properties favours the presence of other properties of the kind (due to causal mechanisms), but not in a necessary sense. Thus, it is not necessary for an individual to share all the properties of the kind.

According to Diéguez, life understood as a homeostatic property cluster is characterized by satisfying part of the properties of the kind favours the presence of other properties, but not necessarily. As a result, in absence of a set of necessary properties, the demands from a metaphysical point of view are lower than in the case of traditional essentialism. In second place, causal mechanisms ensure the realism of the proposal, that is, kinds are not a mere convention. Finally, boundaries of life are fuzzy, since it is not necessary for all individuals to satisfy all properties associated with the kind.

Diéguez's proposal is based on the idea of homeostatic property cluster developed by Boyd (1999). Thus, the difficulties that Diéguez must solve are the same ones that Boyd must face. First, according to Khalidi (2013), some causal mechanisms that justify natural kinds do not tend towards equilibrium, so they are not homeostatic. This question is something that must be taken into account in complex concepts, such as life.

Ereshefsky (2010) is more critical. According to this author, Boyd prioritizes the relationship of similarity when establishing homeostatic natural kinds. So those kinds prioritize relations of similarity to historicity (although it is not incompatible with it). However, Ereshefsky considers that there is a priority in evolutionary aspects compared to similarity relations. Therefore, Boyd's theory is inadequate, at least in historical sciences, such as biology.

On the other hand, Craver (2009) expresses his objections based on the way in how the relevant causal mechanisms are selected. As the author shows, the same process can be studied through different causal mechanisms. Such mechanisms are not only different, but sometimes they are also incompatible. According to what criteria can one prioritize versus another? In Craver's opinion, the choice is given by the interests of the researchers, what it means to overcome the metaphysical priority implicit in Boyd's proposal.

Ferreira and Umerez (2018) propose some modifications on the basic homeostatic theory in order to solve their problems. Thus, based on the idea of stability developed by Slater (2015), they modify some of the most problematic aspects, such as the role of mechanisms. To do this, they substitute the mechanisms for the concept of relevant stability. In any case, the problem 
raised by Craver persists, since it is not clear how the relationship between the relevant stability and the epistemic role of scientific practices is articulated. Of course, it is possible to leave the proposal open, although this assumes the vagueness of the proposal.

In order to define life, another possibility is to consider promiscuous naturals kinds. Although this way has not explored to define life, it was used by Dupré (I98I; I 999) and others to define species. Unlike what happens with homeostatic natural kinds, promiscuous kinds have no metaphysical commitments, only epistemic ones. According to these commitments, it is possible to classify the same entities in different ways (crosscutting natural kinds). This allows Dupré to overcome the difficulties pointed out with respect to the homeostatic kinds. And this is because in this case there are no metaphysical commitments articulated through causal mechanisms.

Nevertheless, this proposal should not be confused with conventionalism. The fact that there are multiple ways of classifying reality does not mean that such ways are stipulated. It is interesting to remember that Dupré is declared realistic, although in other promiscuous authors, such as Brigandt (20 I I) this commitment seems more diffuse. On the other hand, promiscuous proposals are interesting from the point of view of complex concepts such as life, insofar as they allow different disciplines to use different criteria, without having to adopt a conventional approach.

However, promiscuous proposals, even showing an interesting way to define the concept of life, must be able to clarify some aspects. One of the most confusing is the criteria that justify the realistic commitment. Although Dupré shows a realistic commitment, it is not clear according to which criteria is declared as such. No, of course, from any metaphysical commitment, which are openly rejected. Without a more precise clarification of this point, this type of proposal may have difficulty distinguishing it from conventionalism, especially in those authors like Dupré who insist on realism as something characteristic of their proposals. Here it is interesting notice that, according to Brigandt, there is a gradation between natural and conventional kinds, that is, there is not a precise limit between them.

\section{IS LIFE A PROMISCUOUS NATURAL KIND?}

At this point, it can be clearly seen that not only essentialist proposals, but also homeostatic ones, have difficulties in giving an account of the concept of life. On the other hand, understanding natural kinds in a promiscuous way offers some advantages. First, promiscuous natural kinds are compatible with 
the diffuse limits of the concept of life. In addition, to the extent that such kinds depend on the interests and values of researchers, it is not necessary to define every kind in exactly the same way, in different disciplines. This allows, for example, to classify cetaceans and fish within the same kind, according to hydrodynamic criteria. A final advantage, perhaps the most interesting, is that promiscuous natural kinds are compatible with the real scientific praxis (remember the cases of Luisi and the Viking program) while other proposals face difficulties in this regard.

It is true that some of these advantages are also found in other nonessentialist proposals (Diéguez and Ferrreira and Umerez). But these proposals have difficulties to justify the objections pointed out by Khalidi, Ereshefsky or Craver, something that does not happen in the case of Dupré, because he does not consider metaphysical justifications. Complex concepts, such as life, do not lend themselves to justifications of this type. Instead, promiscuous proposals allow focusing on scientific practices, making it possible to distinguish those that are successful from those that are not, according to epistemic and axiological criteria. However, this has repercussions on the way of understanding natural kinds.

This leads to an important issue that cannot be overlooked. A good part of the issue comes from accepting the realism/conventionalism dichotomy. This is not place to analyze this problem, rooted in opposing philosophical traditions (Putnam I 988). However, it is important to consider that this problem underlies the debate on how to define the concept of life (and natural kinds in general). Indeed, authors with metaphysical commitment seek to find those mechanisms that ensure that kinds are not a mere conventions, as conventionalists claim.

Something that follows from what has been said so far is that to consider the concept of life within this debate has not helped to solve the issue. That is why here it is proposed to leave this framework. Instead, it is intended to shift the focus of attention towards how researchers use complex scientific concepts, such as life, in line with Bich and Green's (20I7) research. However, unlike such authors, here it is showed that there are non-essentialist ways to understand natural kinds that can be understood operationally.

The main problem of promiscuous theories comes, precisely, from not accepting with all its consequences the epistemic and axiological commitments as opposed to the metaphysical ones. In complex scientific concepts appear a plurality of aspects that cannot be studied from the real / conventional simplification. Instead, it is possible to use promiscuous kinds as tools capable of allowing the development of scientific disciplines, in an open, plural and revisable way. Which is precisely what scientists seem to do in their investigations. 
Following Hacking (2007) and Brigandt (201 I), it is possible to say that the idea of natural kinds has an undesirable metaphysical baggage per se. Natural membership is considered as a human-independent characteristic of natural kinds. This is something explicitly assumed in essentialist natural kinds. However, this idea underlies also homeostatic and promiscuous natural kinds, although more subtly. In fact, this human-independence seems to be, in some sense, before the insistence by Dupré on realism. That is the reason why Brigandt proposal is, perhaps, more interesting than other promiscuous ones. According to him, there is not a precise border between natural and nonnatural kinds, "I do not think that there is any clear-cut metaphysical boundary between natural kinds and other kinds" (175).

Considering this, could be interesting to define life as a promiscuous natural kind? The concept of life is assumed by researchers as an empirical tool, neither in a strong essentialist sense nor in a conventional one. So the dichotomy between realism and conventionalism is not useful in complex concepts, such as life. And is not the way used by researchers to consider the concept of life. Life only can be considered as a natural kind overlooking this dichotomy. This, if possible, only can be done in a promiscuous framework.

As a conclusion, if were possible to consider life as a natural kind, promiscuous natural kinds could be best candidate among the different types of natural kinds. But as can be seen, the metaphysical baggage of the concept of natural kind as is commonly understood contradicts the way in which natural kinds are considered by the most promiscuous authors. Which are, precisely, those that best seem to adjust when defining the concept of life as a natural kind. Perhaps, if were not possible to adjust the concept of natural kind to this weak metaphysical commitment, it could be replaced by a different term. As a proposal, the concept of scientific category could adopt the epistemic characteristics of promiscuous natural kinds without metaphysical commitment. In any case, answering this question is not the target of this paper, and therefore this will be left open for a later discussion.

\section{Conclusions}

Debates on concepts such as species have developed different theories about natural kinds, as homeostatic or promiscuous kinds, among others. Nevertheless, authors who consider life as a natural kind do so from a rather limited perspective. They only consider life as a natural kind in an essentialist sense, with a strong metaphysical commitment. As noted, Diéguez and Ferreira and Umerez are an exception, as they open the debate to new possibilities. In 
addition, there are other alternatives that have not been explored. Considering life as a natural homeostatic property cluster, and specially understanding life as a promiscuous kind, it is possible to overcome the difficulties pointed out by critics.

Behind essentialist proposals lies a problem of greater scope, namely, the way to justify the realism of natural kinds. According to this the debate moves towards how to justify the metaphysical commitments of such kinds. However, considering life in such terms does not seem to solve the issue. This is the reason why some authors choose to defend that life is a conventional concept, or simply propose to abandon its study. Against this, it is intended to highlight that epistemic and axiological aspects are inseparable of complex concepts. For this reason it lacks sense, as is commonly assumed in natural kinds, to establish a line of separation between the real and the conventional aspects.

In scientific practices, researchers use concepts such as life in a much more open way than that proposed by metaphysical essentialism. Proposals are reviewable according to the empirical results, and therefore they are not mere conventions or stipulations. That is why taking into account the way in which complex concepts such as life are defined can be useful in the development of research. Among the possible options, promiscuous theories are characterized to focus on epistemic and axiological aspects against metaphysical and realistic commitments.

So it is possible to define life as a promiscuous kind, and it could be interesting for researchers to do that. Instrumental and operational definitions could be useful in order to guide scientific research, providing not only theoretical frameworks, but also tools to design experiments and to assess them. But in any case the simplistic dichotomy between realism and conventionalism must be overcome.

\section{Acknowledgments}

I would like to thank Cristian Saborido (UNED) and Alba Amilburu (Universidad del País Vasco) for their valuable comments and suggestions. Jaime Soler is supported by the Spanish Ministry of Science, Innovation and Universities under grant FFI2017-89639-P. 


\section{REFERENCES}

Benner, S. A. 20 io, "Defining life", Astrobiology, 10 (10): 1021.

Benner, S. A.; Ricardo, A.; Carrigan, M. A. 2004, "Is there a common chemical model for life in the universe?", Current opinion in chemical biology, 8 (6): 672-89.

Bich, L.; Green S. 20i 8, "Is Defining Life Pointless? Operational Definitions at the Frontiers of Biology", Synthese, 195 (9): 3919-46.

Bor Luen TAng 2012, "A Minimal or Concise Set of Definition of Life is Not Useful", Journal of Biomolecular Structure and Dynamics, 29 (4): 613-4. DOI: $10.1080 / 073911012010525003$

Boyd, R. I99I, "Realism, anti-realism and the enthusiasm for natural kinds", Philosophical Studies, 61 (1): 127-48.

Boyd, R. I999, "Homeostasis, species, and higher taxa”, R. WiLson (ed.), Species: New interdisciplinary essays, Cambridge: MIT Press, 141-85.

Brigandt, I. 2003, "Species Pluralism Does Not Imply Species Eliminitivism", Philosophy of Science, 70 (Proceedings): 1305-16.

BRIgANDT I. 20 I I, "Natural kinds and concepts: A pragmatist and methodologically naturalistic account”, J. Knowles \& H. Rydenfelt (ed.), Pragmatism, science and naturalism, Berlin: Peter Lang Publishing, 171-96.

Cleland C. E.; Chyba C. F. 2002, "Defining 'life", Origins of Life and Evolution of the biosphere, 32 (4): 387-93.

Cleland, C. E. 20 I 2; 20 i I, "Life without definitions", Synthese, 185 (1): 125-44.

Cleland C. E.; Copley S. D. 2005, "The possibility of alternative microbial life on Earth”, International Journal of Astrobiology, 4 (3-4): 166-73.

Craver, C. F. 2009, "Mechanisms and natural kinds", Philosophical Psychology, 22 (5): 575-94.

Damiano L.; Luisi P. L. 20io, "Towards an Autopoietic Redefinition of Life", Origin of Life and Evolution of Biospheres, 40: 145-9.

DiÉguez, A. 2007, "La relatividad conceptual y el problema de la verdad: Bases para un realismo ontológico moderado", Contrastes. Revista Internacional de Filosofía, 12: 71-91.

Diéguez, A. 2008, “¿Es la vida un género natural? Dificultades para lograr una definicion del concepto de vida", ArtefaCToS, 1: 81-100.

Diéguez, A. 2013, "Life as a homeostatic property cluster", Biological Theory, 7 (2): 180-6.

Dupré, J. I98 I, "Natural kinds and biological taxa”, Philosophical Review, 90: 66-90.

Dupré, J. 1993, Disorders of things: Metaphysical foundations of the disunity of science, Cambridge, MA: Harvard University. 
Dupré, J. I999, “Are whales fish”, D. Medin \& S. Atran (ed.), Folkbiology, MIT Press, 461-76.

EReshefsky, M. 20io, "What's wrong with the new biological essentialism", Philosophy of Science, 77 (5): 674-85.

Ferreira, M.; UMEREZ, J. 20 i 8, "Dealing with the changeable and blurry edges of living things: a modified version of property-cluster kinds", European Journal for Philosophy of Science, 8: 493-518.

Ganti, T. 2003, The Principles of Life, Oxford University Press.

Hacking, I. 2007, "Natural Kinds: Rosy Dawn, Scholastic Twilight", Royal Institute of Philosophy Supplements, 61: 203-39.

Hermida, M. 20i6, "Life on earth is an individual", Theory in Biosciences, 135 (1): 37-44.

Keller, E. F. 2002, Making sense of life: Explaining biological development with models, metaphors, and machines, Cambridge, Mass: Harvard University Press.

Khalidi, M. 20I3, Natural Categories and Human Kinds. Classification in the Natural and Social Sciences, Cambridge: Cambridge University Press.

Lange, M. I996, "Life, 'artificial life' and scientific explanation", Philosophy of Science, 63 (2): 225-44.

Luisi, P. L. I998, "About various definitions of life", Origins of Life and Evolution of the Biosphere, 28: 613-22.

Luisi, P. L. 2006, The Emergence of Life. From Chemical Origins to Synthetic Biology, Cambridge: Cambridge University Press.

Luisi, P. L. 201 5, "Chemistry Constraints on the Origin of Life", Israel Journal of Chemistry, 55 (8)): 906-18. Web

Machery E. 201 2, "Why I Stopped Worrying about the Definition of Life... and Why You Should as Well”, Synthese, 185 (1): 145-64.

Mariscal, C.; Doolittle, W. F. 20 i 8, "Life and life only: a radical alternative to life definitionism", Synthese: 1-15.

Maturana Romesín, H.; Varela, F. J. 2008, De máquinas y seres vivo. Autopoiesis: La organización de lo vivo, Santiago de Chile: Editorial Universitaria [7a ed.].

Moreno, A.; Fernández. J. I997, "Definición de vida y universalización de la biología”, Arbor, 621: 101-12.

Oкаsна, S. 2002, "Darwinian metaphysics: Species and the question of essentialism", Synthese, 131 (2): 191-213.

Pace, N. R. 200I, "The universal nature of biochemistry", Proceedings of the National Academy of Sciences of the United States of America, 98 (3): 805-8. DOI: $10.1073 /$ pnas.98.3.805

Popa, R. 2004, Between Necessity and Probability: Searching for the Definition and Origin of Life, Heldergberg: Springer. 
PopA, R. 201 2, "Merits and Caveats of Using A Vocabulary Approach to Define Life", Biomol Struct Dyn, 29 (4): 607-8.

Putnam, H. I988, Razón, verdad e historia, Madrid: Tecnos.

Razetto-Barry P.; Ramos-Jiliberto R. 201 3, ¿Qué es autopoiesis? Autopoiesis: Un concepto vivo, Santiago de Chile: Editorial Nueva Civilización, 27-57.

Ruiz-Mirazo, K.; Peretó J.; Moreno A. 2004, "A universal definition of life: autonomy and open-ended evolution", Origins of Life and Evolution of the biosphere, 34 (3): 323-46.

SaGan, C. I970, "Life", Encyclopedia Britannica, Chicago, 1083-1083A.

Slater, M. 20I4, "Natural Kindness", The British Journal for the Philosophy of Science, 66: 375-411.

Smith, K. C. 20I6, "Life is hard: countering definitional pessimism concerning the definition of life", International Journal of Astrobiology, 15: 277-89.

Smith, K. 2018, "Life as Adaptive Capacity: Bringing New Life to an Old Debate”, Biological Theory, 13 (2): 76-92.

Tirard, S.; Morange, M.; Lazcano, A. 20io, "The Definition of Life: A brief History of an Elusive Scientific Endeavor", Special Collection of Essays: What is Life? Astrobiology, 10 (10): 1003-9.

Trifonov, E. N. 20II, "Vocabulary of definitions of life suggests a definition", Journal of Biomolecular Structure and Dynamics, 29 (2): 259-66. DOI: $10.1080 / 073911011010524992$

Tsokolov, S. 20го, "A theory of circular organization and negative feedback: defining life in a cybernetic context", Astrobiology, 10 (10): 1031-42. 

QUADERNS DE FILOSOFIA VOL. VI NÚM. 2 (20I9): 43-6I

eISSN: 234I-3042 DOI: I0.7203/QFIA. 6.2.I6054

JULIA JAKOBI ${ }^{1}$

Universität Hamburg

\title{
The Egalitarian Quality of Lottocracy
}

Received: 15/7/19. Accepted: 16/9/19

\begin{abstract}
Recently, political models which employ lottery-selection instead of ballot voting have been proposed. Proponents argue that such lottocratic models can improve the representation of the population and reduce undemocratic influences. In this paper, I argue that these proposals also satisfy the egalitarian requirement of democracy. I claim that having an equal chance to be selected by lot is equally egalitarian as having an equally weighed vote for two reasons: first, having a chance to be selected by lot satisfies the requirement for political justice better than electoral democracy and second, it provides citizens with an equal chance on political influence and not merely equal impact.
\end{abstract}

Keywords: lottocracy, procedural democracy, political equality, political fairness, egalitarian democracy.

\section{INTRODUCTION}

T $\mathrm{T}$ IS WIDELY HELD THAT DEMOCRACY is the most desirable political system, 1 at least amongst those currently at choice. Nevertheless, it has always been questioned and debated whether or not there are political systems that could be preferred, and if so, why. For instance, several authors have doubted that democratic systems can claim any authority towards their citizens at all (cf. i.a. EstLund 2008; Huemer 20 I3). And although it is broadly defended that political systems should be democratic in order to be legitimate, democracy is, however, a very vague concept that allows for a high range of different pro-

${ }^{1}$ Mail to: julia.jakobi@uni-hamburg.de. 
cesses and organizational characteristics. Originally, the term "democracy" derives from the ancient Greek words "demos", the people, and "kratos", strength (cf. ROBERTSON 2004, 136). Thus, literally speaking, any form of government might be considered democratic as long as the political power is ultimately in the hand of the totality of the (adult) citizens and no smaller group has the power to rule. One famous definition of democracy describes it as "government of the people, by the people, for the people" (LinCOLN I 863).

It is often assumed that a government by the people requires a general and equal right to vote for all citizens. But historically speaking, elections have not always been an element of democracy. In ancient Greece, for example, political offices were distributed via lot amongst all citizens ${ }^{2}$ (cf. FucHs 2009, 39f). Discussions and deliberation on political decisions were held in public during which every citizen was allowed to express his opinion on a topic. The randomly selected citizens were then in charge to enact the politics decided upon. Officials were replaced every year so that almost every citizen held a political office at least once in a lifetime (Ibid., 40). As a result of an increasing population such inclusive democracies were replaced by representative democracies: market-place discussions were transferred into parliament and lottery selection was replaced by elections as an element of participation and inclusion of the general public (Ibid., 41). Nowadays, only states which hold elections are considered democratic, but, from a historical point of view, elections have not always been taken as a necessary element of democracy.

Recently, political theorists have proposed different lottocratic models which reintroduce the use of lotteries as an element of political systems (cf. i.a. Fishkin, 2009, 2018; Guerrero, 20I4; López-Guerra, 201 i ; SaunDeRS, 20io; VAN ReYBroucK, 20 i 8). They argue that through lottery-selection the participation of the general public could be enhanced, the impact of lobbyists and economic interests reduced, the demographic representation of the population enlarged and the acceptance of controversial political decisions improved. Experiments with randomly selected citizen assemblies have generated positive results both in terms of the quality of the decisions and of the perception of the decision-process (cf. i.a. BERBNer et al. 20I7; FISHKIN 20I8; Van Reybrouck 20I6).

When it comes to justifying democracy as the desirable political system, mainly two lines of argumentation are employed: democracy is stressed to be valuable for either instrumental or egalitarian reasons. Instrumental accounts of democracy argue that, compared to other decision-methods, democratic decision-making generally leads to good and epistemically valu-

\footnotetext{
${ }^{2}$ Only men of a certain class were considered decent citizens; women, slaves and other people from lower and working classes were not included in the selection of politicians.
} 
able results (cf. i.a. ARNeSON 2009; EstLund 1997). Egalitarian arguments of democracy, by contrast, refer to the intrinsic value of equality which is inherent to the method and independent from the consequences of the decision. Such intrinsic arguments stress the importance of procedural fairness and the general virtue of the equality of all citizens (cf. i.a. Christiano I996A; 2018).

If one generally accepts that democratic systems are justified, then, in order to legitimate the aforementioned lottocratic proposals, it has to be justified that such systems would satisfy the instrumental and the egalitarian value of democracy or it has to be shown that only one of these dimensions is relevant in order for something to be a legitimate and desirable political system. Generally, I follow the first of these approaches and assume that a political system should satisfy the instrumental and egalitarian requirements. In this paper, however, I focus merely on the egalitarian value of lottocracy. The aim of this paper is to show that lottocratic systems satisfy the intrinsic and procedural value of democracy in a relevant way despite depriving people of their general right to vote, a right which is typically considered the characteristic of equal participation in political decision-making. I will not address the epistemic quality of the proposed lottocratic model. I consider the quality of the decisions taken a necessary criterion for legitimating a political system, but I have to leave the evaluation of this quality for another discussion.

The criticism raised against electoral democratic systems is to a certain degree unfair: whenever it comes to evaluating lottocratic proposals one can only discuss ideal, potential designs of them, while the criticism brought forward against electoral systems is based on non-ideal, actual realizations. In what follows, I do not intend to argue that the lottocratic proposal is the only system which could mitigate the problems of current electoral democracies, nor that electoral systems could not be improved in a way to avoid some of the criticism. Instead, I want to evaluate the democratic potential of such lottocratic models in terms of political equality.

I will begin by giving a brief introduction to how a particular lottocratic system is supposed to work (Section 2). I will then outline why political equality is generally considered a necessary element of a desirable political system (Section 3). Next, I will discuss two possible understandings of political equality and question to what extent the lottocratic model could satisfy them: first, political equality as political justice (Section 4) and second, political equality as vertical equality of influence (Section 5). Finally, I will summarize my arguments in order to evaluate the democratic potential of lottocracy (Section 6). 


\section{LOTTOCRACY}

In this paper, I will focus on one extreme proposal for lottery-selection within political systems put forward by Alexander Guerrero (2014). He proposes a model which he calls Lottocracy and in which politicians would no longer be elected but be randomly selected out of the totality of all citizens currently entitled to vote. Other proposals in a similar vein discuss lotteryselected assemblies with advisory functions (FISHKIN 2009; 2018), distributing the right to vote by lottery (López-Guerra 20II) or randomly selecting one final decision out of all votes casted (SAUNDERS 20IO). I will focus on Guerrero's proposal for two reasons: I consider it most comprehensive and promising in order to address the criticism put forward against electoral democracies and it builds on positive empirical findings made in so called citizen assemblies and mini-publics (cf. i.a. FisHKin 2009).

The basic idea of a lottocracy is that politics are no longer made by an elected parliament but by members of the society, which are randomly drawn by lot from the totality of all citizens currently entitled to vote 3 . In order to get a better grasp of the idea of lottocracy I will briefly outline some of the main points of Guerrero's proposals. Nevertheless, my arguments do not hinge on the specific set-up of the system but basically on the fact of replacing a right to vote by a chance to be selected.

Guerrero is very detailed in explaining some of the aspects of the system but completely leaves aside others. He only focuses on the composition and operation of the legislative branch, the parliament, but does, for example, not address the selection of the executive branch, the government. In Guerrero's proposal, the randomly selected people would become full-time, paid politicians for three years. They would get relevant expert-input on political topics, participate in deliberations and become empowered and qualified to take informed decisions on topics relevant to the society. Every year one third of the selected people would be replaced by a new lottery in order to ensure a constant workflow while at the same time rotating the group of politically active people and frequently integrating new and unbiased perspectives. People would not be obliged to serve once they are drawn, but the financial incentives would be considerable and the civic culture should be developed in a way that serving as a politician is "one of the most significant civic duties and honors" (GUerRERO, 20I 4: 156). Guerrero points out that, considering the current costs of the

\footnotetext{
${ }^{3}$ Whether there should be restrictions such as a maximum age, health conditions or a criminal history to exclude people from the possibility of being selected is one of the practical issues that this paper does not focus on, as well as the question whether people could be obliged to take over a political office.
} 
political system in the United States, each selected member of the legislature might be paid something between US $\$ 500,000$ and US $\$ 1,000,000$ per year. Already smaller amounts than these should make it highly attractive for the larger part of the population to assume a political job for three years especially since efforts would be made to accommodate family and work schedules, provide relocation expenses and to guarantee the return into former jobs $s^{4}$. There should be some mechanisms to exclude people who frequently do not show up, who show up intoxicated or who are disrespectful or offensive, but these mechanisms would have to be set in a way that they "protect those who simply are unlikable or who have divergent views" (Ibid., 156).

An intensive deliberation phase, consisting both of expert-input and extensive discussions with other members or the legislature, who might have very different attitudes or social background, is one of the core elements of the lottocratic system 5 . In addition to the internal deliberation, Guerrero proposes that the selected politicians should also interact with the general public somehow, for example through virtual discussion platforms or, better, by going back into their home regions and holding something like town-hall meetings or panel discussions. Thereby, they could both inform nonmembers about the issues and proposals under discussion and gather information of the public's opinions and concerns (Ibid., 162).

This paper will not question the practical setup of the system nor the quality of its decisions. Questions that would have to be answered are how the experts should be selected, whether people can be forced to become politicians, whether there should be a combination of elections and lotteries, who would take on representative functions and the like. I will skip all such considerations and, given the positive results of different experiments with randomly selected citizen-assemblies, assume that integrating the general public into the political

${ }^{4}$ For reasons of individual freedom and autonomy it seems highly disputable whether one could force someone to spend three years of her life in a job that he or she has not chosen voluntarily, to serve the society in a way that most other citizens never do and to interrupt whatever other occupation he or she is currently following. Such an obligation would require a substantial justification that will not be further pursued or debated in this paper. It would have to be discussed elsewhere to what extent the quality of the system might be questioned if participation is voluntary.

5 The selection of these experts is one crucial point in Guerrero's proposal to ensure the quality of the decisions and the absence of manipulation and unfair influences. It requires a "qualification assessment process" to determine if a person counts as an expert and an "expert selection process" to decide which qualified experts are given the opportunity to speak. I will not further discuss a feasible mechanism of expert selection here. For the course of this paper it shall suffice to assume that some good and fair way of integrating experts into the process could be established. Moreover, when it comes to criticizing the influence of experts, it should be kept in mind that all currently practiced political systems do in some way build on advisory services, which are oftentimes not strictly regulated or democratically legitimated. 
system by lottery selection instead of by ballot voting is somehow promising. In the following, I will focus on the question whether such a system could claim to fulfill the egalitarian virtues of democracy.

\section{The Value of Equality}

Before entering into the analysis of different possible interpretations of political equality I will briefly mention some general assumptions on why it is considered valuable at all. There are two lines of arguing for equality as the relevant criterion and justification of democracy: One that stresses the intrinsic value of equality and one that values the procedural advantages of equal consideration given the epistemic limits of knowledge and agreement. The value of equality of all human beings is widely accepted and, inter alia, stipulated in the first article of The Universal Declaration of Human Rights:

All human beings are born free and equal in dignity and rights. They are endowed with reason and conscience and should act towards one another in a spirit of brotherhood.

Although many philosophers have tried to argumentatively prove the desirability of equality, it is often accepted to have an intrinsic value that needs no formal proof (cf. i.a. RaWLS I97I) ${ }^{6}$. As Thomas Christiano puts it

It is an elementary requirement of justice that individuals ought to be treated equally if they are equal in the relevant ways and may be treated unequally if they are unequal in a relevant way. Each person has an equally important life to live, so there is a strong presumption in favor of his or her interests being given equal consideration (CHristiano i996B, 33).

A second line of argument that justifies democracy due to its egalitarian value stresses the procedural fairness of democratic systems. Proceduralist justifications of democracy favor fair procedures as the relevant criterion for justifying democracy. They argue that it is sometimes difficult to identify the epistemic quality of political decisions and that due to the existing pluralism of values and the lack of shared convictions on morality, religion, the best economic system and the like, it is often difficult to reach an agreement about controversial decisions which may not have only one, correct result (cf. CoHEN I996, 18). Proceduralists therefore stress the procedural value of democracy,

\footnotetext{
${ }^{6}$ For interesting counter positions to this assumption see i.a. Frankfurt (1987; 2000).
} 
arguing that the fact of being a fair and egalitarian procedure gives people reasons to accept decisions which might not be clearly judgeable on epistemic grounds (cf. EstLund I997, 174f).

Given the difficulty of reaching content-based agreement, proceduralists argue that it is more important to focus on decision procedures that can be accepted by everyone affected. They claim that the virtue of being an "intrinsically fair political procedure [...] can outweigh some shortfall in production of good consequences" (ARNESON 2009, 200) and that electoral democracy ${ }^{7}$ delivers fair results because it takes into account the opinion of every citizen equally. Thus, democracy leads to a solution that appropriately considers the different opinions present in a society. Procedural arguments build on the intrinsic value of equality and rate it higher than the ideal, but according to them unrealizable, aim of epistemically best decisions.

Of course, merely procedural justifications of democracy are frequently criticized. It is often argued that majority rule can lead to unfair, undesirable and content-wise inferior results. Moreover, critics claim that a merely procedural approach to political decisions is problematic since it is self-defeating: if disagreement on matters of principle are to be solved by fair procedures, how ought one decide which procedure is fair, given the disagreement on principles? (cf. CHRIsTIANO I996B, 35). On the other hand, proponents of proceduralism stress the intrinsic value of treating people equally and consider democratic majority rule an intuitively desirable system. In this paper, I am not concerned with solving the disagreement between proceduralists and instrumentalists and will not further discuss criticism against both positions here. Given the amount of convincing arguments for egalitarian positions, I will assume that a desirable political system has to somehow accommodate the value of equality. As Charles Beitz states it, "no theory of democracy that failed to give the egalitarian idea a central place could possibly yield a faithful representation of the extraordinary grip of democracy on the modern political imagination" (I989, xi). The proposed lottocratic model would deprive people of one important form of equal participation: it would replace their equal vote by only an equal chance on becoming selected as a politician. Several interpretations of political equality exist and I will show how lottocratic models satisfy some relevant interpretations of political equality and why they do so even better than current electoral democratic systems. In what follows, I will elaborate on two interpretations of political equality and the respective egalitarian potential of a lottery-based political system.

${ }^{7}$ Throughout this paper, I will often refer to what is commonly considered a democracy - to electoral, representative democracy - when I speak of "democracy" although I want to challenge whether not a system with universal lottery selection of politicians instead of elections could be called democratic as well. 


\section{Political Equality as Political Fairness}

I will first consider a procedural interpretation of political equality and suggest that political equality ought to be understood as political fairness. When it comes to claiming political equality necessary for something to be a desirable political system, it has to be defined how political equality should be interpreted. The claim for political equality demands to establish fair terms of participation which treat all citizens as equal and in a fair manner. Formulations such as "providing everyone with an equal say in politics" or "providing everyone with an equal opportunity to influence politics" are often used synonymously, but I want to put forward that egalitarian requirements towards a political system can be satisfied by an equal but relevant opportunity on significant influence, even without providing everyone with an equal say. Lottocratic systems would deprive people of an equal say in politics but provide them with an equal chance on relevant influence.

Political equality is often said to imply that the power to take political decisions is equally in the hand of all people. The adequate decision procedure to enact popular sovereignty is often assumed to be one which provides every citizen with an equal say in political decisions. According to most egalitarian democrats, "political equality implies that each and every citizen ought to have a say" (Christiano I996B, 45) in political decisions. I want to argue that providing people with an equal say is one interpretation of political equality but not the unique or best one. To say that the people are sovereign and govern themselves does not necessarily mean that everyone has to have an equal say. In electoral democracies, all citizens have an equal vote but every vote has a very small actual influence. An equal vote seems to rather a symbolic than consequentialist value. But what I take to be, what I take to be the more relevant interpretation of political equality is to have an equal opportunity on meaningful political participation.

Let me support this claim with some numbers ${ }^{8}$. In Germany, in the last elections 61.5 million people were entitled to vote. They elected 709 Members of Parliament. If everyone had participated in the elections, the voice of every voter would have had an impact of $0.0012 \%$ on the election

${ }^{8}$ In the following, I will build my argumentation on numbers and ratios from Germany. It might make a slight difference if the number of people living in a jurisdiction is significantly smaller, but I assume that mathematics of large numbers would lead to similar results in most democratic states. The figures are only approximate and simplified calculations. I will not further discuss the German electoral system with its particularities of a so-called mixed-member proportional representation or the like. I only provide these numbers in order to catch a glimpse of the dimensions under discussion here. 
of one member of the parliament. In other words: every Member of Parliament is elected by 86,700 people; every vote influences the composition of the parliament by $0.0000017 \%$.

How relevant is the voice one has in politics if every four years one can influence the election of one of about seven hundred Members of Parliament by a share of $0.0012 \%$ ? Given these numbers, I question if the claim for political equality, expressed by an equal say, should be interpreted to be a consequential claim. Instead, I consider it to be a rather symbolic claim. I grant that political equality should be understood as equalizing the public status of democratic citizens (cf. BEITZ I989, 16f), but I do not think that this is best done by providing everyone with an equal vote. I do not question that providing people with equal votes is a possibility of realizing a certain kind of political equality, but I question if it is the best we can do in order to achieve meaningful political equality. Instead, I suggest that political equality should be understood as providing citizens with equal procedural opportunities to influence political decisions. Charles Beitz equals the opportunity to influence political decisions with having equal power over outcomes (cf. I989, $4 \mathrm{f})$, but I doubt that these two interpretations of equality do indeed imply the same. As I have pointed out above, it is questionable whether practically all citizens can be provided with a relevant power over political outcomes at all. I do not question the claim for procedural fairness, but I suggest that political equality can also be realized by an equal distribution of access to relevant political influence. Although the lottocratic proposal does not provide everyone with power over political outcomes, it does provide an equal opportunity on influence.

Ronald Dworkin argues that the aim of any political process should be to improve equality of political power (cf. DwORKIN 1987, 117f). He interprets political equality not necessarily as an equal say in politics but as an ideal striving for an equal distribution of political power. Elections are only one means to provide people with political power, but a very un-influential one. As I have pointed out, actual numbers suggest that providing people with one vote every four years does not provide every single one of them with significant power at all.

When the opportunity of gaining political power is evaluated, not only the active right to vote but especially the passive right to become elected should be considered. Although, legally speaking, in most electoral democracies every adult has both an active and a passive voting right, it is questionable to what extent the passive right to vote is indeed realized. The necessity of a significant financial wealth for becoming a politician in the US is frequently discussed, but also in Germany systemic hurdles prevent 
people from becoming politicians with actual, significant influence9 . Political offices are mainly accessible to people with a solid financial background and a relatively high educational level. Research suggests that the passive voting right, the right to become an eligible candidate, is in many societies effectively not realized ${ }^{10}$ (cf. i.a. GUerrero 20 I 4; Helm 20 I7). In Germany, beside of the elected members of the parliament, between 1000 and 4000 people can be considered to constitute a powerful, political influential but not democratically legitimated elite, as sociologists specialized in researching social elites state (cf. i.a. Cwiertnia 20i 8; Hartmann 20i8).

When it comes to equalizing access to real political power, providing people with an actually equal chance of becoming a politician seems to be more promising than to provide people merely with a right to vote. To equalize the distribution of political power, systemic hurdles have to be reduced and the access to political offices has to be improved. Regarding such an equal distribution of political power, a lottocratic system would provide people with an actual chance on political power. In most electoral democracies, all people are provided with an equal vote but effectively only few are provided with a possibility to become politically influential. I do not suggest that lottocracy is the only way to improve the access to political offices or that electoral democracies could not be improved with regard to a more effective realization of a passive voting right. What I want to point out here is that the lottocratic proposal does realize a relevant claim for political equality and does so better than electoral democracies currently do maybe even better than they can do in an ideal realization, given that elections always require some kind of pre-selection of eligible candidates.

So far, I have suggested that political fairness is a sufficient realization of the requirement of political equality. I have argued that political equality has a rather symbolic than a consequentialist value if it is provided by giving

\footnotetext{
${ }^{9}$ The political scientist Marion Reiser found that candidates in the parliamentary elections have to finance large parts of their election campaigns privately. The political scientist Bernhard Weßels states that the direct candidates of the largest two parties paid in average between $10,500 €$ and $6,600 €$ of their private money for their campaigns which were financed to only $13-50 \%$ by their parties (cf. HeLm 20I7). In the US, campaign financing is even way more expensive (cf. GUERRERO 2OI4).

${ }^{10}$ The accessibility of political offices can be doubted, given that the composition of the parliament is not at all representative for the composition of the society. The last German parliament consisted of academics by $91 \%$ while the society as a whole consists of less than $15 \%$ academics (cf. Schmidt-Mattern 20is; Statistisches Bundesamt 20I7). Migratory backgrounds and age structures are equally underrepresented in the parliament. Legally it is provided, but effectively it is questionable if young, female migrants really have the same passive voting right a fifty-year-old German men.
} 
people one vote in elections. The political power one has by having one vote is so small that a system that provides the citizens with actual influence in a fair way might be more promising. What is important to realize political fairness is that people are treated as equals and have equal access to political offices, but this does not necessarily imply that all political rights have to be distributed equally amongst all. The requirement of political fairness can be sufficiently satisfied as long as the terms of participation are such that no citizen has sufficient reasons to deny them, given the general desire to come to an agreement on some mechanism of participation. A fair, political system should not exclude any member from a right on political participation or discriminate against anyone based on gender, race, education or the like. I have outlined that the current electoral system tends to discriminate some people based on their social, educational and financial backgrounds and that therefore some people hardly have access to actual influence, since their right to vote has almost no impact. To support this claim that people have reason to strive for a political system that provides them with a relevant impact, I will elaborate on a relevant understanding of political influence in the next section.

\section{Political Equality as Vertical Equality of Influence}

To illustrate further the demand for equalizing the distribution of political power, I want to build on a distinction proposed by Ronald Dworkin. Dworkin differentiates, on the one hand, between horizontal and vertical political equality, on the other hand he understands political equality as either equality of influence or of impact. This distinction might help to illustrate what kind of equality lottocratic systems can provide and especially provide better than electoral democratic systems.

With horizontal equality he refers to an equal political power amongst individual citizens or groups of individuals. With vertical equality he refers to an equal political power between private citizens and individual officials (cf. DwORKIn I987, 121). Such vertical equality seems to be both unrealistic, because it is impossible to provide every citizen with the same power as a congresswoman or the president, and not necessarily desirable regarding the complexities of political systems and the capacities required to take good political decisions. To demand that every single citizen has the same impact on political decisions would undermine the concept of representation, which aims to transmit the power of the citizens to some chosen, competent representatives. 
Nevertheless, to ignore the vertical inequality of power, between the citizens on the one hand and some selected politicians or otherwise influential elites on the other hand, contradicts the claim for political equality. Electoral democracies might be said to realize an equal horizontal power amongst all people, but this does not yet satisfy the requirement of an equally distributed political power if one understands political power as "the capacity to realize a possible desire, or to get what one wants, despite resistance" (BeITZ I989, 8). Having one equal vote does not provide one with the same power as an elected politician or a member of the influential elite. To demand only equality of horizontal power seems to be no sufficient criterion for a system to satisfy the claim for political equality in a relevant way: even in a totalitarian system all people (except the dictator) have the same horizontal power - none - and also in a one-party-system every person has the same say - one vote - but no actual choice and influence on political outcomes. Thus, a merely equal distribution of votes amongst all citizens is not a sufficient requirement for a fair distribution of power. What is necessary instead is to provide them with an equal and relevant impact on politics. Even if a system provides everyone with an equal and influential vote, one cannot claim that such a system actually provides everyone with the same power: only a selected amount of people - the elected politicians and some other influential people - is provided with effective political power, while the actual influence of the will of every single voter is questionable.

Dworkin, therefore, introduces another relevant dimension for measuring the quality of political power: the distinction between equality of impact and equality of influence. These categories can be described as follows:

someone's impact in politics is the difference he can make, just on his own, by voting for or choosing one decision rather than another. Someone's influence, on the other hand, is the difference he can make not just on his own but also by leading or introducing others to believe or vote or choose as he does (DwORKIN I987, 122)

The influence one has depends on non-constitutional facts such as "the power of charisma or reputation or association or skill or threat or bribe or other advantages that give any one person influence over the political acts of anyone else" (Ibid.). Although having a same vote provides one with the same impact, such non-constitutional facts make the actual influence of every voter unequal. Given the above-mentioned non-constitutional conditions like charisma or potential of bribery, the opinions of some people are more influential than the opinions of others. When these more influential people 
change their opinion, they have the power of changing the voting-behavior of others. Although they still possess only one, equally weighed vote, they can convince others to change their votes accordingly. When a non-influential, average voter changes her opinion, this does only change one single vote. While the political structure, the voting rights and the constitutional facts of a community are relevant for the impact of every single voter, the non-constitutional power of charisma, reputation, network and others determine the influence of a single voter.

This distinction helps to solve the dilemma stated above: vertical equality of impact is impossible and horizontal equality of impact is not necessarily significant. But vertical equality of influence would indeed improve the responsiveness of a political system and horizontal equality of influence could solve the problem of minorities not having any chance of imposing their interests. As mentioned above, the simple condition of a same vote does not say a lot about the quality of a democracy. Equal impact, therefore, is not necessarily a relevant criterion for a fair distribution of political power. Equal influence is a more helpful concept instead. It includes such relevant features as a right on freedom of speech and association, which are necessary virtues for a system to be a democracy. Someone's impact in politics is not smaller than someone else's impact if one of them is denied the freedom of speech while guaranteed a right to vote, but his political influence is reduced unfairly if he is denied such a right to speak.

The concept of horizontal equality of influence can also help to explain another serious complaint about current democratic systems, namely the fact that some financially or medially powerful people have disproportionally more political power than others although they are only citizens and no elected politicians (cf. i.a. Guerrero 20i4; Hartmann 20i8). Such people have the same impact as any other voter but they have more influence due to their networks and their possibilities of reaching and influencing other people. According to Richard Arneson it is especially a difference in horizontal influence that we consider unfair. A society is considered more democratic the closer it comes to achieving equality of influence, that is, the more independent access to political offices and influence on political decisions become from social status, social networks, sex, race, education level and the like (cf. Arneson 2009, 199).

The distinction between equal impact and equal influence helps to justify the egalitarian value of lottocracy. I will argue that providing everyone with an equal chance to gain considerable influence by being drawn by lot outweighs the deprivation of a guaranteed but minimal equal impact through a right to vote. Given the aforementioned intrinsic value of equality 
and procedural fairness, I take it as granted that political power should be distributed equally ${ }^{11}$.

I have elaborated earlier on the mathematically small weight of every single vote (cf. i.a. ARneson 2009, 201; KolOdNy 20 I4, 218). I take this as a starting point in order to support the claim that an effective chance on influence is in a relevant way more egalitarian and therefore more important than a guaranteed right to vote. Mathematically speaking, the chance of becoming drawn by lot as a politician would still be pretty small. Nevertheless, in a lottocratic system the access to political influence would become more egalitarian because systemic and contingent hurdles to democratic access would be reduced. Electoral democracies provide every citizen with the same impact, but proponents of lottery-based proposals criticize the very fact that political influence is distributed highly unequally in electoral democracies ${ }^{12}$ : mainly contingent factors such as charisma, financial power and social networks influence who becomes politically influential. The impact of such contingent factors could be cut out, or at least significantly reduced, in lottocracies and effectively everyone would have the chance to gain political influence, also people from lower social strata, with lower educational levels or smaller social networks.

Electoral systems, at least as they are designed and practiced at the moment, do effectively not provide everyone with an equal chance on political influence. As Aristotle puts it, elections are oligarchic and only the lot is democratic, because elections do already preselect certain candidates to be eligible, while lottery-selection does provide everyone with the possibility to become selected (cf. AristotLe, 350bc (i 885 ) book IV, part ix, 1294b). Electoral systems, as they currently are, are not egalitarian for two reasons: on the one hand, the passive right to be eligible is effectively not realized for everyone; on the other hand, the politicians eligible do oftentimes not provide one with the possibility of being demographically represented, that is represented in terms of age, educational background, values or the like. The process of elections is in a certain way selective, thus that the elected politicians and people politically committed are over all not demographically representative to the society and

${ }^{11}$ Besides of the intrinsic motivation of this demand, proponents of equal access to political power also stress the instrumental value of including as diverse opinions and skills as possible in political decision making. Critics question whether the benefits of cognitive diversity and descriptive representation do really outweigh the cost of losing the presumably positive traits of charisma, personal motivation and expertise which elected politicians might have. Again, I have to leave this discussion of instrumental arguments to another occasion and will focus on the equality of access to political influence here.

${ }^{12}$ Again, this is not supposed to imply that lottocracy is the only way to reach such an improvement. Electoral systems might be improved in a way to provide people with an equal chance on influence, but I am concerned with pointing at the egalitarian potential of lottocracy here and not with suggesting improvements of electoral democracy. 
therefore their opinions are likely not to cover all topics or options relevant to the different groups of the society. In a lottocracy, people from all social strata could be selected and would be more representative for the society as a whole than current politicians ${ }^{13}$.

The concept of demographic representation is important for my claim that lottocracy would distribute political influence more equally than electoral democracy. Representation is considered an institutional device to make democratic decision-making possible when numbers are too large (cf. LANDEMORE $2013,105)$. Representation can be understood as "acting for someone" or "descriptively standing for someone" (cf. PITKIN 1972). Arguments for a form of political representation, where some people are selected in order to act for others mainly build on some special abilities these selected have, such as rhetorical competence or intellectual expertise on a topic. But this causes the problem that elections "tend to bring to power socially and economically homogenous people. [... These] people are likely to share some personality traits (a type A personality, say) or other characteristics that may reduce the overall cognitive diversity of the assembly" (LANDEMORE 2013, 108). This cognitive diversity is what a descriptive understanding of representation aims at. Research has shown that the quality of decisions highly depends on the amount of different perspectives included in a decision, rather than on the cognitive ability of every single participant of the deliberation. The Diversity Trumps Ability Theorem holds that "a randomly selected collection of problem solvers outperforms a collection of the best individual problem solvers" (PAGE 2007, 163) ${ }^{14}$. Empirical experiments have shown that "groups of average citizens perform decently well when placed in the right deliberative conditions" (LANDEMORE 20I3, 109). If the aim is to reproduce the diversity of the society, elections are not the best way of ensuring this, since, at least in current electoral systems, they

${ }^{13}$ Considering the laws of probabilities, it is of course not guaranteed that a lottery-based parliament could represent all minorities of a society, it is not even guaranteed that social structures would be roughly mirrored at all. Nevertheless, what lottery-based selection could overcome at once are systemic hurdles, which currently hinder some people from becoming eligible or elected. Lottery-selection is of course not the only way to solve this problem and ideal electoral democracies would not impose such systemic hurdles. Still, probabilities are higher in lotteryselected groups than in election-based systems that members of currently under-represented groups get selected. A completely random selection cannot ensure the representation of minorities but makes it more likely than the current election system. Some proponents of lotterybased systems propose to implement quota in order to ensure the representation of minorities. I cannot elaborate on the advantages and disadvantages of such proposals here further but am aware of the need to address the problem of ensuring the representation of minorities, which I claim lottery-selection could provide, elsewhere. Thanks to an anonymous reviewer for pointing out the need to clarify this.

${ }^{14}$ For an interesting and illustrative description of this see Landemore (2013, 99-102). 
tend to bring to power people with similar personality traits and social backgrounds. When it comes to descriptive representation, random lotteries would produce "'an exact portrait, in miniature, of the people at large', ensuring a statistical similarity of thoughts and preferences of the rulers and the ruled" (Ibid., 108). In order to reach as much cognitive diversity as possible, without knowing beforehand which perspectives, concerns and convictions might be needed to come to the best solution, "it seems that the best solution is not to choose but to leave it up to chance and the law of large numbers" (Ibid., 115).

The claim for descriptive representation blurs the line between the procedural and the instrumental quality of democracy. Although I generally want to exclude content-related arguments in this paper, including the quality of deliberation has definitely both a procedural and an epistemic aspect. The argument for aiming for a descriptive representation rather than for a representation in the sense of acting for someone builds on the epistemic quality of the decision taken. But the consequence of demanding such a descriptive form or representation is a procedural one. In order to generate a descriptive representation of the society, the procedure of random selection is more feasible than elections.

If one understands representatives as actually "communicating" with the people they represent, and as merely expressing their opinions, then demographic representation might be rather irrelevant. But if one understands representation as representing the people's attitudes and cognitive abilities, then descriptive demographic representation becomes more important (cf. PIтKIN I972). The problem of political representation is that a political representative is "neither an agent nor a trustee nor deputy nor commissioner; he acts for a group of people without a single interest, most of whom seem incapable of forming an explicit will on political questions" (Ibid.). Therefore, the most relevant understanding of representation seems to be to mirror the opinions present in a society. Political representation should ensure that the opinions of all people are equally present in a governmental action, and this is likely to be realized better when the people are descriptively represented and not merely acted for by someone.

I can now consolidate the two lines of argument developed above. I have spelled out why the desirable form of political equality should be an equal influence rather than an equal impact. Besides, I argued that political representation should be rather descriptive than in the sense of acting for someone. Elections provide everyone with an equal impact but with only a limited access to political influence. The impact of every single vote is diminishingly small and insignificant. The chance on actual political influence is distributed very unevenly in electoral democracies and would be distributed fairly in lottocracies. Given the fact that, practically speaking, not everyone can have a significant 
influence, I argued that descriptive representation is more promising in order to ensure that everyone's interests are addressed than an acting-for representation. In order to mirror the attitudes and the diversity of the society, random selection is a promising procedure to distribute the chance on influence procedurally fair and to reproduce the cognitive diversity of the society. Even if one is not selected, one's own interests and attitudes would probably be represented better in a demographically descriptive parliament than in a parliament where one has merely the chance to elect people which tend to be mainly from one social strata.

\section{Conclusion}

The aim of this paper was to examine the egalitarian quality of so called lottocratic political systems. At first glance, depriving people of their right to vote might seem to violate the basic requirements of political equality and participation. Still, I claimed that lottocratic systems do nevertheless satisfy a relevant understanding of equality.

First, I pointed out that electoral democracies are highly un-egalitarian themselves when it comes to equality of influence or the representation of demographic facts. I argued that an equal chance on being selected can be considered a sufficient realization of procedural accounts of democracy and therefore satisfies the requirement of political fairness. Second, I put forward that given the minimal mathematical impact of every single vote and given the merits of a descriptive account of representation, vertical equality of influence should be considered a more relevant form of political equality than a guaranteed equal but small impact.

Having shown that lottocratic systems can be considered egalitarian in a relevant sense, the legitimacy of lottocratic systems seems to depend mostly on their instrumental value and the epistemic quality of their decisions. This issue is, however, left for future research.

\section{Acknowledgements}

I would like to thank the participants of the XX Taller d'Investigació en Filosofia 2019 in Valencia and Thomas Krödel, Stephan Schmid and the participants of their research colloquium at the University of Hamburg for very helpful comments on earlier drafts of this paper. Moreover, I am thankful to Moritz Schulz for providing me with the financial funding to realize this paper. 


\section{BiBLIOGRAPHY}

Aristotle (350bc (i 885$)$ ), Politics (B. Jowett, trans.), Oxford: The Clarendon Press.

Arneson, R. J. 2009, "The Supposed Right to a Democratic Say", T. Christiano \& J. Christman (ed.), Contemporary Debates in Political Philosophy, West Sussex: Wiley-Blackwell, 197-212).

Beitz, C. R. I989, Political Equality - An Essay in Democratic Theory, Princeton, NJ: Princeton University Press.

Berbner, B. et al. 20i7, 2.2, „Zur Wahl steht: Die Demokratie“, Die Zeit. Retrieved from https://www.zeit.de/2017/04/rechtspopulismus-demokratiewahlen-buer gerversammlungen-politisches-system-griechenland. Accessed: 20.02.2019

Christiano, T. i996a, "An Argument for Democratic Equality", T. Christiano (ed.), Philosophy and Democracy. (2003), Oxford, New York: Oxford University Press, 39-68.

Christiano, T. г996в, "Democracy As Equality”, D. Estlund (ed.), Democracy, Oxford: Blackwell Publishers, 31-50.

Christiano, T. 20 18, "Democracy", The Standford Encyclopedia of Philosophy, Fall 2018 Edition, E. N. Zalta (ed.). Retrieved from https://plato.stanford.edu/ entries/democracy/\#Bib.

Cohen, J. I996, "Procedure and Substance in Deliberative Democracy", T. Christiano (ed.), Philosophy and Democracy. (2003), Oxford, New York: Oxford University Press, 17-38.

Cwiertnia, L. 20i 8, 9.8, „Sie leben in einer völlig anderen Welt“, Die Zeit. Retrieved from https://www.zeit.de/2018/33/michael-hartmann-eliten-soziologie-soziale-gerechtigkeit. Accessed 20.02.2019.

Dworkin, R. I987, "What is equality? Part 4: Political equality", T. Christiano (ed.), Philosophy and Democracy. (2003), Oxford, New York: Oxford University Press, 116-37.

Estlund, D. I997, "Beyond Fairness and Deliberation”, J. Bohman \& W. RehG (ed.), Deliberative Democracy, Cambridge, Massachuesetts: MIT, 173-204.

Estlund, D. 2008, Democratic Authority - A philosophical framework, Princeton, Oxford: Princeton University Press.

Fishkin, J. S. 2009, When the People Speak, Oxford: Oxford University Press.

FishKin, J. S. 20 I 8, Democracy when the people are thinking: revitalizing our politics through public deliberation, Oxford: Oxford University Press.

Frankfurt, H. I987, "Equality as a Moral Ideal”, Ethics, vol. 98 (1 (Oct., 1987)): $21-43$. 
Frankfurt, H. 2000, “The Moral Irrelevance of Equality”, Public Affairs Quarterly, vol. 12 (2): 87-103.

Fuchs, D. 2009, „Demokratie“, D. Fuchs \& E. Roller (ed.), Lexikon Politik, Stuttgart: Reclam.

Guerrero, A. A. 2014, "Against Elections: The Lottocratic Alternative”, Philosophy \& Public Affairs, vol. 42 (2): 135-78.

Hartmann, M. 2018, Die Abgehobenen: Wie die Eliten die Demokratie gefährden, Frankfurt: Campus Verlag.

Helm, M. 2017, 14.9, „Wenn Wahlkampf eine Frage des Geldes ist“, Süddeutsche Zeitung. Retrieved from https://www.sueddeutsche.de/politik/bundestagswahl-wenn-der-wahlkampf-eine-frage-des-geldes-ist-1.3624810. Accessed 20. 02.2019.

Huemer, M. 2013, The Problem of Political Authority - An Examination of the Right to Coerce and the Duty to Obey, Hampshire: Palgrave Macmillan.

Kolodny, N. 20 I4, "Rule Over None I: What Justifies Democracy?”, Philosophy \& Public Affairs, vol. 42 (3): 195-229.

Landemore, H. 2013, Democratic Reason, Princeton, NJ: Princeton University Press.

Lincoln, A. I 863, "The Gettysburg Address", W. E. Gienapp (ed.), This Fiery Trial: The Speeches and Writings of Abraham Lincoln (2002), Oxford: Oxford University Press.

López-Guerra, C. 20 i I, "The Enfranchisement Lottery", Politics, Philosophy and Economics, vol. 10 (2): 211-33.

Page, S. E. 2007, The Difference: How the Power of Diversity Creates Better Groups, Firms, Schools, and Societies, Princeton, New Jersey: Princeton University Press.

Pitkin, H. F. I972, The Concept of Representation, Berkley and Los Angeles: University of California Press.

Rawls, J. I97I, A Theory of Justice, Cambridge: Harvard University Press.

Robertson, D. 2004, “Democracy”, D. Robertson (ed.), The Routledge Dictionary of Politics (3rd ed.), London, New York: Routledge.

Saunders, B. 20 io, "Democracy, Political Equality, and Majority Rule", Ethics, vol. 121 (1, October 2010): 148-77.

Schmidt-Mattern, B. 2015, Deutschlands Akademiker-Parlament. Deutschlandfunk. (ed.). Köln: Deutschlandradio. Retrieved from http://www. deutschlandfunk.de/demokratie-deutschlands-akademiker-parlament.862. de.html?dram:article_id=334191. Accessed 9.7.2017.

Statistisches Bundesamt, destatis. 2017, Bildungsstand - Bevölkerung nach Bildungsabschluss in Deutschland. Wiesbaden: Statistisches Bundesamt. Retrieved from https://www.destatis.de/DE/ZahlenFakten/GesellschaftStaat/BildungForschungKultur/Bildungsstand/Tabellen/Bildungsabschluss.html. Accessed 21.3.2018. 
United Nations, The Universal Declaration of Human Rights (1948).

Van Reybrouck, D. 2016, Gegen Wablen - Warum Abstimmen nicht demokratisch ist, Göttingen: Wallstein Verlag.

Van Reybrouck, D. 20 i 8, Against Elections - The Case for Democracy, New York: Seven Stories Press. 
QUADERNS DE FILOSOFIA VOL. VI NÚM. 2 (20I9): 63-87

eISSN: 234I-3042 DOI: I 0.7203/QFIA. 6.2.I I 406

Francisco Fandos Marí ${ }^{1}$

Universidad Nacional de Educación a Distancia (UNED)

\section{¿Tiene cabida el justiciero en las sociedades democráticas? Una respuesta desde el mundo del cómic}

Received: 23/1/18. Accepted: 3/2/19

Resumen: En el presente artículo se reflexionará en torno a la figura del justiciero y su posible encaje en las actuales sociedades democráticas. Se abordará la relación de incompatibilidad entre la idea del Estado legitimado para el uso de la violencia y la figura del justiciero. Cómo desde el mundo del cómic ha sido representado no como un defensor de la justicia sino como alguien que actúa al margen de la ley.

Abstract: The following article will propose a reflection about the figure of the avenger and how he could fit into current democratic societies. Also, the relation of incompatibility between the legitimation of the State for using the violence and the role of this kind of avenger will be addressed. How from superhero's comic-books an avenger has been represented not as a defender of justice but as someone that acts on the fringes of the law.

Palabras clave: justiciero, democracia, legitimación, justicia, héroe, cómic.

Keywords: avenger, democracy, legitimation, justice, hero, comic.

\section{INTRODUCCIÓN}

$\mathrm{B}$ ajo la antropológicamente pesimista (¿o realista?) visión de Hobbes, en un estado de guerra de todos contra todos surge la imperiosa necesidad de generar un pacto en el que se garanticen unas mínimas condiciones

${ }^{1}$ Contacto: fanditos@hotmail.com. 
de conservación de paz y seguridad en la ciudadanía ${ }^{2}$. El problema surge ante el precio que se haya de pagar por la consecución de dicho objetivo de paz y seguridad.

Uno de los múltiples retos para la difícil convivencia entre iguales reside en los responsables de generar dicho pacto. Fruto de ese pacto es el Estado, donde se tendrán que buscar los equilibrios en torno a las naturales necesidades y deseos individuales con el denominado bien común en el marco y los límites de la legitimidad que procura un régimen democrático. Dicho equilibrio resulta fundamental para evitar una figura que, lejos de encarnar las mejores de las virtudes en un gobernante, se convierta en una suerte de referente contrario al sistema con más sombras que luces en el desempeño de su tarea o "misión salvífica": el justiciero; polémico y ambiguo en su interpretación de la justicia.

Como plantea Raymond Aron en la introducción a la obra El político y el cientifico de Max Weber, "la moral del hombre de acción es ciertamente la moral de la responsabilidad"3. La responsabilidad en el desempeño de su labor debe ser un valor esencial para lograr el éxito en este cometido sin dejar de lado la vigilancia a los derechos fundamentales. ¿Quién podría llevar a cabo tal empresa? En el siguiente artículo se reflexionará acerca de esta cuestión bajo una óptica filosófica pero ligada también a la representación que del héroe se ofrece desde el mundo del cómic. De este modo se presentará un marco teórico y su posterior reflejo en el ámbito del cómic de superhéroes para ofrecer una posible solución al planteamiento que da lugar al título de esta reflexión, esto es; si un justiciero tiene cabida en las sociedades democráticas. Esta idea servirá como hilo conductor pues la tesis central es que un justiciero no es un héroe y por tanto no tiene razón de ser en una democracia.

En primer lugar, se tratarán de acotar adecuadamente una serie de términos ligados al a veces confuso y ambiguo lenguaje jurídico para sostener una base teórica a partir de la cual pudiese dar sentido a alguien ajeno al poder legítimamente establecido. A partir de ahí, se abordará la cuestión acerca de qué pueda motivar la aparición de una figura alternativa al sobrentendido garante de la convivencia pacífica y democrática en un Estado.

A continuación, siguiendo a Weber, se analizará la figura del líder carismático y su posible analogía con el justiciero; alguien que se configura como un líder carismático ad hoc y cuyo proceder, sobrepasando la legalidad, es autolegitimado sobre la base de ese pretendido carisma. Además, se reflexionará sobre la posible perversión de justificar la aparición del justiciero cuando el sistema garante de nuestras libertades puede fallar o quedar en entredicho.

${ }^{2}$ Hoвbes, Thomas, Leviatán, cap. XIII, Madrid: Ed. Sarpe, 1983, p. 176.

${ }^{3}$ Weber, Max, El politico y el cientifico, Madrid: Alianza Editorial, 2015, p. 36. 
Delimitar el rol del héroe será básico para diferenciarlo de su contrapunto, el justiciero (que no el villano ${ }^{4}$ ) y valorar cómo el actuar de cada uno de ellos es muy distinto así como también lo es la consideración ética de sus actos.

También habrá que buscar en la justificación del justiciero la dicotomía no resuelta que contrapone los valores de libertad y seguridad y que el mundo del cómic ha sabido representar tan acertadamente. Seguidamente, desde la perspectiva del universo cinematográfico y las viñetas del cómic de superhéroes, se contrapondrán los modelos del héroe y del justiciero para señalar la idoneidad de uno frente al otro en un modelo social democrático.

Finalmente a modo de epílogo, se valorará de nuevo la tesis central sostenida en el artículo; que un justiciero no puede ser un héroe. Se recalcará la idea de la inadecuación de un justiciero en una democracia. Yendo incluso más allá, se cuestionará la conveniencia de un "héroe" que, aun estando dentro de los límites de la ley, se alce como una suerte de autoridad moral por encima de los individuos de su propia comunidad. Bajo esta óptica, más que plantear la dicotomía justiciero-héroe, se dejará la puerta abierta a la reflexión sobre si es necesario un héroe con unas "cualidades especiales" por encima de aquel ciudadano anónimo y ordinario que desempeña su actividad cotidiana en el marco de la comunidad política en la que se inserta. En síntesis: si es deseable un estandarte moral; si son necesarios hoy los héroes y, en todo caso, qué clase de héroes.

\section{MARCO TEÓRICO: ¿OSTENTAR O DETENTAR EL PODER?}

El justiciero ha planteado no pocos interrogantes morales por su posible acomodo en el seno de una democracia. El punto de partida para abordar tales interrogantes serán las ideas que expone Max Weber en la conferencia pronunciada en invierno de 1919 sobre La política como vocación. En dicha conferencia se define al Estado como: "aquella comunidad humana que, dentro de un determinado territorio (el territorio es el elemento distintivo), reclama (con éxito) para sí el monopolio de la violencia física legítima". ${ }^{5}$ En virtud de esta definición, el justiciero queda excluido de este modelo de Estado. Por lo tanto, siempre y cuando éste cumpla con su misión de garante del orden y las libertades públicas, nadie podrá justificar la necesidad de una figura al margen de lo establecido legítimamente.

${ }^{4}$ Un villano y un justiciero no tienen por qué ser equivalentes. El villano por definición es ruin e indigno y sus acciones siempre están orientadas al mal. El justiciero puede compartir los mismos objetivos y propósitos que el héroe aunque los medios que utilice no sean necesariamente los más idóneos.

${ }^{5}$ Weber, El politico y el científico, p. 83. 
Haciendo un análisis más minucioso de la citada frase, es esencial precisar debidamente los términos. El término ostentar hace referencia a "mostrar o hacer patente una cosa". ${ }^{6}$ En el caso que nos ocupa, el Estado hace patente efectivamente algo que le otorga el derecho a ciertas prerrogativas. Esto es, al uso de la violencia. Ese algo es la legitimidad para ejercer dicha prerrogativa. Por otro lado, detentar implica "retener y ejercer ilegítimamente algún poder o cargo público". 7 Una dictadura es un ejemplo de la detentación del poder. De lo anterior se puede colegir que, mientras exista legitimidad, el Estado podrá retener exclusivamente para sí tal derecho a esas ventajas.

Por lo que respecta a la idea de legitimidad, también se hace necesario puntualizar algunos aspectos para comprender bien el porqué de la aceptación de una norma en un momento determinado. La legitimidad alude a un reconocimiento. Dicho reconocimiento tiene una doble vertiente. Por un lado, un proceder conforme a la legalidad vigente. El ejercicio legítimo del poder radica en la elección democrática como respuesta de la voluntad general del pueblo y por tanto de la aceptación libre de unos representantes que puedan, llegado el caso, ostentar ese monopolio legítimo de la violencia. Es por tanto capital que las medidas que puedan derivarse de la actuación de estos representantes, se enmarquen en la más pura y nítida legalidad para que sean aceptadas sus consecuencias. Dicho de otro modo, para justificar que el monopolio de la violencia sea verdaderamente legítimo, no puede hallarse ni el más mínimo atisbo de ilegalidad en sus principios fundacionales. La cualidad de lo legítimo implica estar conforme con las leyes. Por ello, el monopolio del uso de la violencia tendrá un encaje en las sociedades democráticas mientras venga determinado por normas que justifiquen lícitamente dicho uso.

Pero ese reconocimiento, esa legitimidad a la que se alude, tiene otra vertiente. Además de la adecuación a la legalidad vigente dentro del modelo de Estado de Derecho en el que cabe enmarcarse, es necesario que exista una aceptación social de la norma. En la medida en que una norma sea justa, no parece que exista motivo alguno para desobedecer la ley. En ese sentido esta acepción de la legitimidad encierra un importante elemento de moralidad. No sirve por tanto que jurídicamente la norma sea impecable, que haya satisfecho todos los requisitos legales necesarios para su aprobación. Expresado más técnicamente, una norma es legítima no solo cuando es aceptada de iure sino también de facto. Y en múltiples ocasiones encontramos cómo el reconocimiento social muchas veces va a un ritmo distinto del reconocimiento legal. Por ejemplo, en España, la ley del divorcio se aprobó en el año 1981, y ob-

${ }^{6}$ DRAE, 21 a edición, tomo II, 1a entrada, Madrid: Editorial Espasa-Calpe, 1995, p. 1492.

${ }^{7}$ DRAE, $21^{\text {a }}$ edición, tomo I, 2a entrada, p. 737. 
viamente existían parejas que habían roto su proyecto de vida en común. En este sentido, el reconocimiento legal llega después del reconocimiento social.

En otras ocasiones, puede darse la circunstancia de que, pese a la existencia de un reconocimiento legal, no venga acompańado por un reconocimiento de la sociedad (o al menos parte de ella). Por ejemplo, la ley sobre protección de la seguridad ciudadana de 1992, llamada también ley Corcuera o "ley de la patada en la puerta", tuvo un reconocimiento legal, habida cuenta de que el gobierno de entonces (presidido por el PSOE de Felipe González) tenía la mayoría necesaria para aprobar la ley. Pese a ello, algunos elementos polémicos de dicha ley fueron llevados ante el Tribunal Constitucional por lo que no hubo un reconocimiento de, al menos, una parte de la sociedad. En la medida en que estas dos dimensiones del término legitimidad entran en conflicto, se podría estar favoreciendo consciente o inconscientemente la aparición de un justiciero. Aquel individuo que, por sus acciones, puede aspirar a ser aceptado social pero no legalmente. Una combinación que podría calificarse, cuanto menos, de temeraria.

Siguiendo con la frase de Weber, además del ejercicio legítimo, se requiere que el Estado lo haga exclusivamente, que ejerza un monopolio. Con toda probabilidad será ésta la única ocasión en la que se permita que el Estado concentre una capacidad de ejercer presión (en este caso, hacer cumplir las normas establecidas) como una prerrogativa sobre los demás. El Estado debe ser el poseedor de ese monopolio puesto que en caso contrario no se podría asegurar una convivencia pacífica en una comunidad en la que sus miembros optaran por ejercer individualmente la violencia al considerar que sus derechos se viesen menoscabados. No obstante, que el Estado ostente dicho monopolio no le exime de ser escrupulosamente escudrińado. Por ello la imagen del justiciero en este contexto excede los límites de la legalidad y la legitimidad.

La ficción ha abordado estas cuestiones con una mayor o menor carga de profundidad ética. En el mundo del cine, un caso paradigmático podría ser Death Wish ${ }^{8}$ donde un ciudadano desencantado con las fuerzas de seguridad decide convertirse en "juez y parte" para asombro y satisfacción de su vecindario y pesadilla tanto para los criminales como para las propias fuerzas y cuerpos de seguridad. La mera existencia de dicho ciudadano vengativo refleja la inacción e inutilidad de una policía que no es capaz de realizar la tarea fundamental que tiene asignada y para la que cobra sentido la afirmación de Weber. Si la policía ya no puede protegernos, si ya no estamos a salvo, ¿̨uién nos defenderá? Por otro lado, el cómic también ha reflejado acertadamente esta figura en múltiples ocasiones. Uno de los más significados tal vez sea The Punisher

\footnotetext{
${ }^{8}$ Death Wish [El justiciero de la ciudad], dir. Michael Winner, act. Charles Bronson, Paramount Pictures, 1974.
} 
(el castigador) ${ }^{9}$ inspirado en las novelas de Don Pendelton, The Executioner. ${ }^{10}$ Uno de los aspectos que resulta especialmente inquietante del personaje, no es tanto su comportamiento al margen de la ley (algo que queda claro a lo largo de sus aventuras) sino la facilidad con la que el lector puede llegar a empatizar con él hasta el punto de no desear que las fuerzas del orden lo eliminen.

\section{JUSTICIA, ¿PARA QUIÉN? El JUSTICIERO COMO LÍDER CARISMÁTICO}

Ante esta situación, ¿qué sentido cabe darle al concepto justicia? ¿Como equidad? Hay una acepción en el diccionario de la Real Academia Espańola de la lengua que refiere el término JUSTICIA como "conjunto de todas las virtudes, por el que es bueno quien las tiene". ${ }^{11}$ Desde esta perspectiva, habría que aceptar el hecho de que un justiciero no posee todas las virtudes pues un individuo virtuoso de verdad, sería respetuoso con la ley y la autoridad establecidas. ¿¿De qué justicia estamos hablando? Hacer un profundo análisis histórico del término nos llevaría a alejarnos de la cuestión central del artículo. Baste decir que a lo largo de la historia de la humanidad, hemos visto múltiples ejemplos en los que un personaje al margen del gobierno constituido se ha elevado por encima de las convenciones (más o menos justas) para simbolizar la lucha contra la tiránica opresión del mal dirigente.

Qué duda cabe que en ocasiones, y por ver la cuestión desde otra perspectiva, el gobernante ha tratado de ser un líder carismático al que seguir y en el que el pueblo pudiera reconocerse, convirtiéndolo así en alguien inspirador. En ocasiones lograr dicha consideración para este tipo de autoridad ha requerido, por así decirlo, de ciertos atajos morales. Uno de los máximos exponentes de esta concepción lo encontramos en el realismo político de El príncipe: “[...] porque un hombre que quiera hacer en todos los puntos profesión de bueno, labrará necesariamente su ruina entre tantos que no lo son. Por todo ello es ne-

${ }^{9}$ The Punisher es un personaje que representa al clásico antihéroe desencantado con la ley y la sociedad corruptas y que atormenta a los criminales bajo un estricto código de conducta moral que sobrepasa claramente todos los límites legales convirtiéndose en un genuino justiciero. Hizo su primera aparición en el número 129 de la revista The Amazing Spider-Man en 1974. Como dato curioso, cabe observar que fue el mismo año en el que se estrenó la película Death Wish lo cual ofrece una idea de la imagen que se tenía del justiciero en la época. Cabe recordar que otro justiciero como el policía de ficción Harry Callahan interpretado por el actor Clint Eastwood, hizo su aparición en las pantallas de cine también en la década de los 70; década abonada para este modelo de antihéroe de moral cuestionable.

${ }^{10}$ Howe, Sean, Marvel Comics: La historia jamás contada, Girona: Panini Comics, p. 141.

${ }^{11}$ DRAE, 21 a edición, tomo II, $4^{\text {a }}$ entrada, p. 1215. 
cesario a un príncipe, si se quiere mantener, que aprenda a poder ser no bueno y a usar o no usar de esta capacidad en función de la necesidad". ${ }^{12}$

Aquí radica uno de los problemas que pueden llevar a instaurar un justiciero en una comunidad. Un líder carismático, ¿debería ser una persona inspiradora? ¿Un ejemplo a seguir? ¿Un referente? Deseamos que nuestros líderes nos representen, que solucionen nuestros problemas, no que los creen. Gestionen nuestros recursos de la forma más eficaz y eficiente posibles y hagan de nuestro mundo un lugar más seguro en el que vivir. Una utopía deliciosa, pero utopía al fin y al cabo.

Y el modelo que aparece en El príncipe difícilmente parecería estar dando respuesta a esas necesidades sociales. Más bien al contrario; facilitan una figura ajena a los códigos de comportamiento aceptables desde una perspectiva ética. No debería ser calificada como una exigencia fuera de lugar el demandar a los gobernantes estar en posesión de unas virtudes que les hicieran ser merecedores de la confianza por parte de los gobernados. Si por el contrario acaban olvidándose de su papel de servidores públicos y defensores de los intereses generales, entonces no podemos luego extrañarnos de que aparezca alguien contrario al orden establecido.

\subsection{Legitimidad del héroe vs. legitimidad del justiciero}

En el planteamiento clásico de Weber sobre los diferentes tipos de legitimidad (a saber, legitimidad carismática, tradicional y racional), ${ }^{13}$ el héroe claramente se ubicaría en la legitimidad racional. No son necesariamente incompatibles entre sí pero en caso de tener que apostar por uno de los modelos, el que se fundamenta en el imperio de la ley, será, a priori, el acertado. La legitimidad que se basa en las tradiciones, la legitimidad "del eterno ayer" puede ser tanto o más reprobable como la apuesta por un modelo sustentado en el carisma del líder. ¿Serían aceptables todas las tradiciones per se? Evidentemente no. Máxime cuando dichas tradiciones pudieran ser fruto de la imposición de quien se erige como líder omnipotente.

Merece la pena volver de nuevo a las reflexiones que plantea Raymond Aron en la introducción a El político y el cientifico de Weber en relación a este líder carismático:

Imaginaba a los mejores de entre ellos (hombres políticos) revestidos de una especie de autoridad carismática. Es muy cierto que las democracias están perpetuamente amenazadas por la decadencia que entrańan el anonimato de los

${ }^{12}$ Maquiavelo, Nicolás, El principe, cap. XV, Madrid: Alianza Editorial, 1995, p. 83.

${ }^{13}$ WeBer, El politico y el cientifico, p. 84. 
poderes, la mediocridad de los dirigentes y la pasividad de las masas sin espíritu. En circunstancias trágicas cuando está en juego la vida de la nación o la Constitución ha de ser restaurada, los pueblos desean seguir a un hombre al mismo tiempo que obedecer a las leyes. [...] En los momentos críticos, los regímenes vivos hacen surgir a las personas capaces de salvarlos. En las épocas tranquilas, los jefes de la democracia son administradores honrados, a veces buenos organizadores y, más frecuentemente, simples conciliadores. El hecho de que tengan también la amplitud de visión, la clarividencia y la pasión lúcida de los grandes hombres de estado constituye un feliz azar con el que, razonablemente, no puede contarse. ${ }^{14}$

En momentos puntuales de la historia tal vez haya podido ser razonable una figura que se eleve, debido a sus características personales, por encima del resto. En ese sentido un líder carismático puede haber funcionado como revulsivo. No obstante, el líder carismático no tiene por qué ser considerado un líder democrático. El carisma que pueda poseer un individuo no le hace depositario de las cualidades exigidas para ser un buen gobernante. Es carismático, por ejemplo, el líder de una secta y no es considerado precisamente digno de loa. Podemos encontrar ejemplos de líderes que apelando a ese carisma han sido capaces de manipular, influenciar, someter a la población en aras de una pretendida "tierra prometida" que, desafortunadamente, no ha llegado. En ese sentido, sin ánimo de polemizar, se podría citar el ejemplo de la Cuba post-Batista donde la dictadura de éste, dejó paso a la utopía de la revolución encarnada por el carismático Fidel Castro. Una esperanza que décadas después tampoco se puede decir que se haya materializado en una mejora real en la calidad de vida de la isla.

También fue carismático, tal vez uno de los líderes más inspiradores de la historia reciente, el presidente John F. Kennedy. Presidente al frente de un país ligado a una edulcorada visión de la década de los 60 como una suerte de "Camelot de cuento de hadas". En cualquier caso, un líder cuyo legado, décadas más tarde, continúa ejerciendo una fuerte atracción y una capacidad de inspirar a generaciones futuras.

Basten estos ejemplos para poner de relieve que efectivamente un líder carismático puede ser inspirador. Sin embargo, la buena voluntad de un líder no puede ser el elemento definitorio de éste. Habida cuenta de que no necesariamente su proceder estará orientado en una dirección proclive a la democracia per se. Cuando ese carisma se pone al servicio de buenas acciones, de un desarrollo social justo y democrático que garantice los derechos fundamentales y en definitiva, mejore la vida de las personas, es, desde luego, deseable. En

${ }^{14}$ Weber, El político y el cientifico, p. 44. 
caso contrario, un líder carismático con una vocación desviada respecto de la democracia, llevaría a un claro abuso y perversión del poder. De las reflexiones que se suscitan, se podría entrever que las circunstancias hacen al justiciero. Ante la dicotomía sobre si éste nace o se hace, bien se podría afirmar al hilo de los planteamientos anteriores que efectivamente se hace. Surge en un momento concreto motivado por unas circunstancias determinadas. $Y$ no es, en absoluto, una situación ni exagerada ni imaginativa ni mucho menos alejada de la realidad.

El ser humano tiende a dar cumplimiento a unas necesidades esenciales. Cuando las necesidades de seguridad y protección, que diría Maslow, no son satisfechas, entramos en una dinámica de ansiedad, frustración, inseguridad, incertidumbre... y ante esa situación no es excesivo considerar a un justiciero carismático (de nuevo el carisma como elemento que justifica su comportamiento ante la sociedad y pueda ser legitimado por ésta) que restaure dichas necesidades insatisfechas. De hecho, en 2016 tuvo una cierta repercusión mediática la historia de un justiciero en México que se enfrentó a cuatro ladrones que robaron en un autobús. ${ }^{15} \mathrm{El}$ anónimo viajero, al parecer se levantó y disparó a los cuatro ladrones causándoles la muerte. Devolvió las pertenencias sustraídas a los propietarios, bajó del autobús y desapareció. Para los pasajeros del autobús había sido obra de un héroe. Para la policía, no. Nadie lo identificaba, nadie afirmaba ser capaz de describirlo o reconocerlo. Qué pudo motivar la reacción de dicho pasajero o incluso la reacción de los demás pasajeros quienes no solo asistieron impasibles al terrible desenlace sino que no dudaron en defender y justificar tal acción, es algo que desde un punto de vista ético merece ser considerado. Lo cierto es que la vulneración de la ley abre unos interrogantes cuanto menos, inquietantes.

Sirva este caso para valorar que, efectivamente en una sociedad donde confluyen variables diversas como la violencia, la corrupción, la inestabilidad, etc., tal vez se pueda estar promoviendo consciente o inconscientemente la llegada de un vengador. Alguien que ante la inacción de los considerados "representantes naturales" de la ley y el orden, desempeñe, sobrepasando la legalidad, una función que en modo alguno se le debe atribuir en el marco de un Estado democrático.

Ante ese posible escenario, debe exigirse la legitimidad racional. Aquella que se fundamenta en el imperio de la ley. En la aceptación de las reglas fijadas, consensuadas por la población en virtud del sufragio y la elección de representantes. Un modelo, el de la democracia representativa, que se constituye como elemento garantista para una legitimidad justa. $\mathrm{Y}$ aunque los diferentes

${ }^{15}$ Martínez Ahrens, Jan, "El misterio del justiciero del autobús sacude México", El País, http://internacional.elpais.com/internacional/2016/11/04/mexico/1478223570_248293.html 7 nov. 2016.11 nov. 2016. 
tipos de legitimidad puedan coincidir en una misma figura, lo verdaderamente importante es que la racionalidad, como si del auriga de Platón se tratara, se imponga sobre cualesquiera otras consideraciones para evitar, precisamente, la aparición de un sujeto que se arrogue para sí un poder que no le corresponde legítimamente. Y para hablar de un marco auténticamente democrático, dicha democracia debe ligarse intrínsecamente a la libertad. Libertad auspiciada y limitada por la ley. Pero por una ley justa. De esto modo, no existirán argumentos que puedan respaldar las tesis de un vigilante ni será posible hallar ningún resquicio dentro del marco de la ley que abone el terreno para la justificación del mismo. Cabe aquí recordar las palabras de Montesquieu al respecto cuando afirma que:

Es cierto que en las democracias parece que el pueblo hace lo que quiere; pero la libertad política no consiste en hacer lo que uno quiera. En un Estado, es decir, en una sociedad en la que hay leyes, la libertad solo puede consistir en poder hacer lo que se debe querer y en no estar obligado a hacer lo que no se debe querer.

Hay que tomar conciencia de lo que es la independencia y de lo que es la libertad. La libertad es el derecho de hacer todo lo que las leyes permiten, de modo que si un ciudadano pudiera hacer lo que las leyes prohíben, ya no habría libertad, pues los demás tendrían igualmente esta facultad. ${ }^{16}$

No hay aquí una visión ingenua o falta de realismo. En ocasiones, las leyes se transgreden. No vivimos en un modelo utópico pero el régimen democrático en el que desarrollamos nuestra cotidianeidad es, a falta de algo mejor, lo que tenemos ahora mismo y convendría cuidarlo o, parafraseando a Churchill, el menos malo de los regímenes políticos. Bien es cierto que, pese a todo, el sistema democrático no es ni mucho menos perfecto. Por ello precisamente es vital mantenerse alerta y expectante ante los posibles abusos del poder para denunciarlos y, llegado el caso, incluso desobedecerlos al modo como plantea Thoreau:

Hay leyes injustas. ¿Nos contentaremos con obedecerlas o intentaremos corregirlas y las obedeceremos hasta conseguirlo? ¿O las transgrediremos desde ahora mismo? Bajo un gobierno como este nuestro, muchos creen que deben esperar hasta convencer a la mayoría de la necesidad de alterarlo. Creen que si opusieran resistencia el remedio sería peor que la enfermedad. [...] Bajo un gobierno que encarcela a alguien injustamente, el lugar que debe ocupar el justo es también la prisión. ${ }^{17}$

${ }^{16}$ Montesquieu, Del espiritu de las leyes, Madrid: Tecnos, 2002, p. 106.

${ }^{17}$ Thoreau, Henry D., Desobediencia civil, Madrid: Tecnos, 2004, p. 40. 
El conflicto aparece cuando desde el seno del propio gobierno legitimado no se hace lo suficiente y acaba surgiendo inevitablemente un "vigilante" externo al sistema. Llegados a ese punto se abre un camino de incierto resultado.

\subsection{Cuando el sistema falla}

Una situación sociopolítica y económica injusta presupone el caldo de cultivo para que pueda instalarse alguien ajeno al sistema. Éste es el justiciero. Pero choca frontalmente con la función que el Estado se tiene asignada para sí como presenta Weber. Por tanto, ¿el justiciero tiene cabida en nuestras sociedades actuales? ¿Es compatible con la democracia? El justiciero no es un héroe. Éste imparte justicia con equidad y no bordea la ley ni, mucho menos, la quebranta. Aquél hace aquello que se debe hacer para conseguir un objetivo desde una perspectiva diríamos que absolutamente maquiavélica. Pero lo suyo no es justicia, sino, en la mayoría de las ocasiones, simple venganza. El comportamiento de un justiciero aunque pudiera ser comprensible, es éticamente reprobable y desde luego, en un contexto democrático, en ningún caso justificable. Admitir su mera existencia implicaría aceptar la venganza como norma habitual de conducta alejándose por tanto de un imperativo ético al estilo kantiano e irremediablemente alejado del sentido más profundo de la dignidad humana. Principio ya no solo esencialmente democrático sino, por encima de todo, moral. Aceptar un justiciero vengador supondría reconocer que el sistema no funciona, que está viciado, que es inútil. ¿Es eso lo que se trata de dar a entender dando cabida a dicho personaje? Y lo que es más preocupante para una sociedad democrática, ¿es lo que se desea? Habría que tener mucho cuidado con abrir la caja de Pandora, puesto que una vez abierta, no hay vuelta atrás. Los males se han escapado. En el momento en que transigimos con una "justicia” paralela a la legalidad vigente, ¿quién nos garantiza su correcta actuación?

Cuando el sistema falla, el justiciero puede ser un revulsivo, una ¿̨necesaria? visión contraria al poder establecido. Pone en jaque a la autoridad promoviendo con su acción una especie de desobediencia civil al establishment. Pero esta situación, sin pretender justificarla, solo puede ser entendida desde la premisa inicial del argumento: cuando falla el sistema. En cualquier caso, no es un argumento con el suficiente peso para poder aceptar una figura al margen de la ley. Tan simple como eso. Suele ser considerado como positivo la existencia de referentes morales. Pero el justiciero no puede erigirse en uno de ellos. Y aquí surge un problema de impredecibles consecuencias. Las referencias morales, los ideales de vida representan algo positivo, algo inspirador. Una influencia adecuada que desde pequeńos, en la familia, en la escuela o en la sociedad vamos recibiendo. Como elemento motivador, vamos proyectando reflejos de 
esos estandartes éticos. Pero claro, siempre y cuando dichas referencias sean las adecuadas. ¿Es adecuado el mensaje que subyace bajo la mentalidad del justiciero? ¿Es la venganza un valor a transmitir? En definitiva, ¿qué referentes queremos? ¿En qué medida no sería arriesgada la apuesta por alguien que decide qué es justo, correcto o equitativo? Y en cualquier caso, ¿`cómo se puede llegar a controlar? Porque al fin y al cabo, el problema no radica en la aparición de una voz que despierte la conciencia de la comunidad. Esto es algo meritorio. El verdadero problema reside en su mera aceptación. Porque una vez "liberado", su control y posterior anulación se convierte en tarea harto complicada. Cerrar nuevamente la caja de Pandora se presenta como una empresa titánica.

\section{3. ¿QUÉ HÉROE? ¿QUÉ JUSTICIERO?}

Como señala Luis Gil en la presentación a El mito del héroe de Bauzá:

La figura del héroe, como la del santo, más que mitos son arquetipos culturales heredados de un pasado remoto en los que la realidad histórica y los embellecimientos de la imaginación se han imbricado inextricablemente. Como tales arquetipos, sirven de ideas-motrices desde el momento en que una sociedad los toma como modelos de conducta. ${ }^{18}$

Esta es la cuestión capital: cuando la sociedad toma al héroe como modelo de conducta, como referente en el que verse reflejado, no vale cualquier tipo de héroe. No todos pueden ser héroes. Por tanto es crucial plantearse qué representación del héroe se pretende adoptar como referente. La figura del héroe queda muchas veces ensombrecida por su propia leyenda. Un héroe es un ídolo que queda mitificado. Las más de las veces el héroe asciende a esta categoría tras desaparecer con la muerte. El mito del héroe desempeña una función social. Es un personaje aglutinador. Puede estar llamado a representar los ideales más elevados de una sociedad pero para ello tiene que convertirse en un verdadero estandarte. En un auténtico referente. En palabras de Bauzá, "lo que más se ha valorado en los héroes es el móvil ético de su acción, fundado éste en un principio de solidaridad y justicia social". ${ }^{19} \mathrm{El}$ héroe ha de ser un acicate hasta el punto de desear emular sus acciones. El marco de acción del héroe está bien delimitado. No es posible un infinito abanico de posibilidades. Su proceder, de alguna manera, queda sujeto y condicionado por la visión que se tiene de él.

${ }^{18}$ GIL, Luis, Introducción a BAUZÁ, H. F., El mito del héroe: Morfología y semántica de la figura heroica, Buenos Aires: F.C.E., 2007, p. ix.

${ }^{19}$ BAuzÁ, El mito del héroe: Morfología y semántica de la figura heroica, p. 5. 
Es la imagen que ofrece Eco cuando destaca al héroe como alguien que "debe ser un arquetipo, la suma y compendio de determinadas aspiraciones colectivas, y por tanto debe inmovilizarse en una fijeza emblemática que lo haga fácilmente reconocible". ${ }^{20}$ Bajo esta óptica, el héroe representa a alguien cuya actuación podría calificarse como previsible, invariable y estática. Se sabe qué se espera de él y se es exigente con él porque "es profundamente bueno, moral, subordinado a las leyes naturales y civiles, por lo que es legítimo que emplee sus poderes con fines benéficos". ${ }^{21}$ Es importante esta cuestión dado que se señala el camino que debe seguir el héroe. Sus poderes podrán ser legítimamente utilizados en la medida que de ellos se deriven beneficios para la población. Ya sea para garantizar su seguridad, otorgar protección o cualquier otra necesidad. Además el héroe por antonomasia es virtuoso. Para Savater, "el héroe no solo hace lo que está bien, sino que ejemplifica por qué está bien hacerlo"22 y con ello convierte en valioso el comportamiento virtuoso. No en la virtud en sí misma sino en el propio ejecutante, esto es, el héroe. Porque allí donde otros fracasan, afirma Savater, el héroe hará posible el "más difícil todavía" triunfará ante las adversidades porque quiere y porque puede.

En el extremo opuesto se sitúa el antihéroe, el vigilante, el vengador, el justiciero. Diversas maneras de referirse a la misma idea: un fuera de la ley. Alguien que tratará de imponer su forma de ver la justicia de un modo poco ortodoxo y que, aun compartiendo elementos con el héroe, fácilmente parece desviarse del ideal heroico. Nuevamente Eco establece los rasgos propios de este dominador al otorgarle una manera de proceder alejada radicalmente de la esencia del héroe: [...] "utiliza métodos antisociales, con arreglo a la ley del talión; el fin justifica los medios, y la justicia debe salir triunfante aunque sea a navajazos" ${ }^{23} \mathrm{La}$ caracterización que se hace de este personaje no invita a pensar en la bondad de sus acciones y, lo que es peor, que dicha conducta suponga una escalada en la que se acabe subvirtiendo el orden legítimamente reconocido abriéndose ante sí un escenario alarmante. Con respecto a personajes de esta índole, Eco advierte:

Y como la sociedad no reconoce esa necesidad de justicia y nunca comprendería sus propósitos, habrán de perseguirlos e intentar realizarlos en contra de la sociedad y de las leyes. Para poder hacerlo deberán estar dotados de cualidades excepcionales y poseer una fuerza carismática que legitime su decisión aparentemente subversiva. ${ }^{24}$

${ }^{20}$ Eco, Umberto, Apocalípticos e integrados, Barcelona: De Bolsillo, 2016, p. 270.

${ }^{21}$ Eco, Apocalipticos e integrados, p. 297.

${ }^{22}$ Savater, Fernando, La tarea del héroe, Madrid: Taurus, 1983, p. 113.

${ }^{23}$ Eco, Umberto, El superhombre de masas, Barcelona: De Bolsillo, 2016, p. 94.

${ }^{24}$ Eco, El superhombre de masas, p. 104. 
Resulta inevitable acordarse del ideal nietzscheano de superhombre. Parecería que este antihéroe aquí propuesto fuera un reflejo de la moral de señores fuertes y orgullosos frente al héroe clásico que bien podría simbolizar una moral de esclavos en la que la amabilidad o la compasión fuesen valores esenciales. ${ }^{25}$

\subsection{La ética como convicción y la ética como responsabilidad}

Tanto el héroe como el justiciero podrían enmarcarse en alguno de los dos modos de entender la ética que plantea Weber: la ética como convicción y la ética como responsabilidad. En líneas generales podría asociarse al héroe con la ética de la responsabilidad y al justiciero con la ética de la convicción. Pero es una analogía algo simplista. En cualquier caso, son dos propuestas que Weber presenta en un primer momento como antagonistas (distintos entre sí e irremediablemente opuestos) hasta el punto de señalar con rotundidad:

No es posible meter en el mismo saco la ética de la convicción y la ética de la responsabilidad, del mismo modo que no es posible decretar éticamente qué fines pueden santificar tales o cuales medios, cuando se quiere hacer alguna concesión a este principio. ${ }^{26}$

Pero no sería correcto hablar respecto a esta distinción, de un posicionamiento claramente maniqueo. A grandes rasgos, el héroe asume la ética de la responsabilidad. Las consecuencias de sus acciones son asumidas con madurez. Por el contrario, la ética de la convicción se centra más en los actos al margen de las consecuencias. Para Weber aquel sujeto con vocación de servicio ${ }^{27}$ debe poseer tres elementos básicos: pasión, sentido de la responsabilidad y mesura (Weber 20 I 5, 151). El héroe podría presentar estas cualidades. ¿También el justiciero? En un comportamiento ligado a la ética de la convicción podríamos hallar una auténtica pasión en el desempeño de la tarea de vigilancia por parte del justiciero. Pero difícilmente se podría acreditar un sentido de la responsabilidad (a no ser que se aceptase un sentido "distorsionado" de la misma) y mucho menos mesura en su proceder. Para el justiciero, la convicción de unos principios puede hacer que se acabe alejando de las nobles motivaciones que sustentaban tales principios. Sin embargo para el héroe, la ética de la responsabilidad sí va asociada a un apasionado altruismo en su acción además de un

\footnotetext{
${ }^{25}$ Esta idea de la moral de señores y la moral de esclavos aparece en buena parte de la obra de Nietzsche. Especialmente en Más allá del bien y del mal o La genealogía de la moral.

${ }^{26}$ Weber, El politico y el cientifico, p. 164.

${ }^{27}$ Para Weber; el político, pero en el contexto que nos ocupa, caben perfectamente tanto las figuras del héroe como la del justiciero pues, en última instancia, ambos tratan a su manera de ofrecer un servicio a la comunidad aunque con métodos diametralmente opuestos.
} 
claro comedimiento en la forma en que lleva a cabo dicha acción. Por decirlo de otro modo, el héroe asume las consecuencias de sus actos. El justiciero no. Y a pesar de esa distinción, el propio Weber finaliza su reflexión al respecto afirmando la complementariedad de ambos tipos de ética: "[...] la ética de la responsabilidad y la ética de la convicción no son términos absolutamente opuestos, sino elementos complementarios que han de concurrir para formar al hombre auténtico, al hombre que puede tener 'vocación política'” ${ }^{28}$

\section{LIBERTAD VS. SEGURIDAD: DICOTOMÍA NO SUPERADA}

Parte del debate en torno al justiciero hay que situarlo en la clásica disyunción entre preponderar la libertad o la seguridad en un Estado. Las disquisiciones éticas se enfrentan al dilema de aceptar un modelo donde se nos garanticen unos valores a cambio de la renuncia a otros. Ese es el sentido que se plantea desde la visión hobbesiana en relación a un modelo de estado que garantiza la seguridad de la ciudadanía a costa de la merma de libertades civiles esenciales. No es una cuestión menor ni mucho menos extemporánea. Citaré un ejemplo de esta dicotomía y cómo se ve plasmada en el mundo del cómic. Los atentados de las torres gemelas de Nueva York en septiembre de 2001 tuvieron como consecuencia (al margen de las pérdidas humanas, claro) el sentimiento de desprotección, impotencia e inseguridad que llevaron a la justificación y posterior aprobación de la patriot act. ${ }^{29}$ Esta ley patriótica pretendía salvaguardar la seguridad del pueblo estadounidense. Se estableció de forma implícita que era necesario "pagar un peaje" por la seguridad de la comunidad para seguir garantizando el american way of life.

En el otro extremo, tras los atentados en Madrid de marzo de 2004, no se planteó una medida similar para España hasta el punto de crear una ley que expresamente restringiera derechos de la población. De manera un tanto simple, se podría decir que EE.UU. apostó por la seguridad en detrimento de las libertades civiles. En España esta medida no se produjo. Sirva este ejemplo para valorar cómo la actuación en un sentido u otro, ante un determinado acontecimiento extraordinario puede llevar a remover las conciencias hasta el punto de poner en tela de juicio el orden democrático establecido y los valores comunes compartidos.

La novela gráfica de Mark Millar, Civil War, ${ }^{30}$ refleja muy claramente esta confrontación entre libertad y seguridad. El argumento gira en torno a un

${ }^{28}$ WeBer, El político y el científico, p. 173.

${ }^{29}$ La ley patriótica fue aprobada tanto en la Cámara de Representantes como en el Senado y promulgada en octubre de 2001 por el entonces presidente George W. Bush.

${ }^{30}$ Millar, Mark y Mcniven, Steve, Civil War, Barcelona: Marvel Deluxe. Panini Comics, 2010 . 
episodio desafortunado provocado por los poderes de un superhéroe (Nitro) que lleva a la creación por parte del gobierno de un acta de registro y control de superhéroes (sucedáneo de la patriot act americana) en virtud de la cual los superhéroes deberán estar registrados con su identidad real y los poderes que poseen y trabajar bajo las órdenes del gobierno. A partir de este momento se entabla una persecución entre superhéroes alineados en dos bandos claramente diferenciados capitaneados por dos personajes paradigmáticos: Iron Man, defensor del acta de registro y que acepta las medidas del gobierno en pos de la seguridad (no deja de ser curioso que el alter ego de Iron Man, Tony Stark, sea un empresario e ingeniero multimillonario gracias a la creación y venta de armamento militar) y por otra parte el Capitán América, paladín de la libertad. Todo un icono que invita a la reflexión. ${ }^{31}$

\section{Justicieros vs. HÉroes de CómiC}

El mundo del cómic (o su posterior traslación al cine) describe un contexto donde resulta difícil trazar la línea divisoria entre la verdadera justicia y el rol del justiciero. Entre la legitimidad de la ley y la aceptación social del vengador. A lo largo de la historia del cómic de héroes y/o superhéroes, hay múltiples referencias a personajes que han ido apareciendo o han sido reinterpretados como justicieros opuestos al sistema.

De entre los diferentes cómics que han planteado esta cuestión, tal vez uno de los más significativos sea el cómic de Alan Moore y David Lloyd, $V$ de Vendetta. ${ }^{32}$ En una distópica Inglaterra, la justicia idealizada por $\mathrm{V}$, ha dejado paso a un régimen totalitario. El protagonista se verá en la obligación de asumir un rol anárquico para enfrentarse a esa tiranía totalitaria. Para V, la justicia es inútil sin libertad y en el contexto que le toca vivir, la libertad brilla por su ausencia y por tanto V se verá abocado a imponer "su" justicia. $\mathrm{V}$ de Vendetta personifica uno de los riesgos más grandes que pueden surgir en relación a la idea del justiciero. En una sociedad democrática, el justiciero no tiene cabida. Pero en una sociedad totalitaria, este personaje, de manera un tanto torticera, se reviste a sí mismo de una pretendida legitimación y ahí radica precisamente el problema. Luchar contra ese modelo totalitario debería plantearse con el objetivo de cambiar dicho modelo por una legítima democracia. Pero no desde la perspectiva de un fuera de la ley porque si se

${ }^{31}$ En 2016 se estrenó la película Capitán América: Civil War en la que se presenta una adaptación de la novela gráfica Civil War con bastantes licencias sobre el original pero en la que se evidencia el debate no resuelto entre libertad y seguridad.

${ }^{32} V$ de Vendetta, Alan Moore y David Lloyd, 6a edición, Barcelona: ECC Ediciones, 2015. 
actúa en este sentido, no puede luego sorprender la aparición de individuos como el propio V o como el justiciero de la ciudad Paul Kersey. ${ }^{33}$

Lo inquietante con respecto a esta idea es que, pese a ser algo mostrado en una novela gráfica, lo cierto es que episodios de este tipo, con mayor o menor grado de exageración, suceden. Según lo dicho, se podría incluso encontrar un paralelismo entre la merma de confianza en las instituciones que nos gobiernan y la aparición de movimientos sociales que canalizan un descontento hacia la política constituyéndose en formaciones al margen del sistema y de los cauces tradicionalmente considerados. Esta podría ser una posible explicación (de entre otras muchas pero que no es objeto de análisis en este artículo) del auge de estos movimientos en países de Europa, como Francia, Grecia, Italia, Austria, Alemania, España o también en Estados Unidos con la elección de un presidente ajeno al mundo de la política y aupado en base a un discurso que podría tildarse de populista y demagógico. ¿Por qué van teniendo más relevancia movimientos sociopolíticos tan alejados de la tradicional visión de la política? De algún modo, la mirada que proyectan los cómics no está tan alejada de la realidad a la vista del contexto geopolítico actual. De hecho, los cómics no son más que un reflejo de la realidad con la que les toca coexistir. Una imagen (a veces, escalofriantemente fiel) de la sociedad y del momento político en que se enmarcan.

Parece claro por tanto que, en la medida en que las necesidades básicas no se vean satisfechas y las instituciones no sean capaces de darles cumplimiento, se abonará el terreno para que una figura crítica aparezca para tratar de doblegar al injusto poder establecido. Los factores que la originan son diversos; algunos han sido señalados ya. Pero cuando el Estado no es capaz de ofrecer una respuesta satisfactoria a las demandas sociales, entonces es razonable pensar que se tenderá a buscar "en otra dirección". Históricamente las desigualdades sociales han lastrado un verdadero progreso y desarrollo de las naciones. $\mathrm{Al}$ mismo tiempo han posibilitado la aparición de modelos anti-sistema, contestatarios... llámense como se quiera. Cuando el Estado no es capaz de garantizar lo que nos es más íntimamente querido (principalmente, nuestros derechos individuales empezando por la seguridad) entonces pierde su legitimidad y en consecuencia, volviendo a Weber, el monopolio del uso legítimo de la violencia se desvanece. $\mathrm{Y}$ en ausencia de un poder claramente tendente al bien común, puede surgir una figura vengativa que distorsione el objetivo principal y se arrogue el derecho de ejercer motu proprio la potestad atribuida de iure únicamente al Estado. Por el contrario, será en tales circunstancias cuando el verdadero héroe y los valores que éste encarna cobrarán, si cabe, mayor sentido.

${ }^{33}$ Ver nota 8. Paul Kersey es el personaje que interpreta el actor Charles Bronson en la película citada. 
Las circunstancias excepcionales por tanto hacen al justiciero. El conflicto aparece cuando, aceptada la premisa de la supuesta ineptitud del Estado para garantizar unos derechos básicos, la alternativa puede llegar a ser tanto o más reaccionaria. Tal es así que un movimiento errático puede convertirse no tanto en solución sino en el inicio de un caos de devastadoras proporciones. Los modelos totalitarios son un claro ejemplo. Cuando los valores morales que dan sentido a un modelo de sociedad democrática son eliminados, se instaura una peligrosa inanidad de la que ya advierte Hannah Arendt, "el totalitarismo busca no la dominación despótica de los hombres, sino un sistema en el que los hombres sean superfluos". ${ }^{34} \mathrm{Y}$ cuando este enfoque totalitario triunfa, se infiltra en todas las esferas de la colectividad una mentalidad proclive a erosionar los pilares mismos de la convivencia. De una convivencia fundamentada en la igualdad, la tolerancia, el respeto y, desde luego, la justicia. Un sistema corrompido rara vez ofrecerá una solución para restaurar ese modelo de convivencia deseable porque además, la propaganda totalitaria consigue "adormecer" primero y deshumanizar a la gente hasta hacer que desaparezca incluso un mero anhelo de libertad y suele desafortunadamente, tener éxito en su empeño. Y esta deshumanización, cuyo máximo exponente lo encarnaron los campos de exterminio, lleva a una podredumbre moral por lo que representa de indigno.

No caben pues equidistancias entre el justiciero y el héroe tradicional. Ambos pueden ser vistos como revulsivos para "poner orden" en una sociedad desnortada. Pero los medios que utilicen uno u otro definirán a los propios personajes y los posteriores acontecimientos que se deriven de sus acciones. El justiciero no puede erigirse como un sustituto que imponga su propia concepción de la justicia. El justiciero, y esto es capital, se sitúa al margen de la ley. Es más; se ubica por encima de ella hasta el punto de arrogarse el derecho de ejercerla a su merced. Por eso es de vital importancia que "la violencia legítima" esté sostenida por un único actor, el Estado, y que dichas atribuciones sean consentidas y aceptadas libremente por la sociedad civil. $Y$ en este sentido, para el mundo del cómic la figura del héroe tradicional no es cuestionable puesto que los intereses que defiende, los métodos que utiliza y el fin que persigue están siempre orientados por unos valores dentro de un marco de democracia ajenos al justiciero.

Los cómics de superhéroes han sido un medio eficaz para presentar un retrato idealizado y romántico del héroe capaz de luchar en pos de un ideal por encima de los propios intereses. El prototipo de aquél que es capaz de sacrificarse por unos principios nobles. Que es capaz de posponer su felicidad o sus intereses particulares por un bien mayor. Tal podría ser el caso de arquetipos

${ }^{34}$ Arendt, Hannah, Los orígenes del Totalitarismo, $3^{\text {a }}$ reimpresión, Madrid: Alianza Editorial, 2009, p. 613. 
como Superman. Este modelo de héroe no es un justiciero. Esos personajes ejemplifican ese anhelo de justicia, de paz y prosperidad para los pueblos pero nunca superando los límites que marcan las leyes. Superman, por ejemplo, es un dechado de virtudes. No actúa inadecuadamente. Superman ni siquiera miente. Este héroe sería la representación del modelo que plantea Luis Alberto de Cuenca cuando señala que "el héroe siempre dice la verdad. Odia la mentira como algo infamante y defiende la franqueza con entusiasmo. Cumple con su palabra, se mantiene en lo que ha prometido. Una palabra, un hombre". ${ }^{35}$ Podría asemejarse al paradigma que en el mundo del cine ha interpretado en múltiples ocasiones el actor James Stewart; un caballero sin espada. ${ }^{36} \mathrm{Y}$ en el caso de Superman, un caballero con capa.

En el otro extremo, se podría situar a Batman, con especial énfasis el Batman reinterpretado por Frank Miller ${ }^{37}$ en los cómics de mitad de los años 80 donde la moral del personaje es ambigua y refleja más la encarnación del justiciero que de un fiel cumplidor de la legalidad. Es ese patrón el que pervive como el peligroso referente moral en la lucha contra la opresión, la injusticia y la corrupción. Y es peligroso por cuanto que al abuso de la ley se debe responder con más ley. O dicho con otras palabras: la desobediencia civil puede estar justificada cuando existen injusticias pero hay que ir con mucho cuidado cuando se buscan subterfugios para tratar de reinstaurar el orden pues tal y como advierte Luther King:

[...] la paz no puede ser simplemente un objetivo distante, sino que son los medios con cuya utilización llegaremos a aquel objetivo. Para alcanzar un fin pacífico, debemos emplear medios pacíficos. Y con estas palabras, como análisis final, pretendo decir que el fin y los medios deben estar en estrecha correspondencia, pues el fin ya está contenido en los medios, y finalmente, unos medios destructivos nunca podrán llevarnos hacia un fin constructivo. ${ }^{38}$

Lo cierto es que un justiciero no incorporará la justicia que realmente se necesita. Tal vez en un principio pueda asemejarse a algo parecido a la justicia, pero es una quimera. Un comportamiento personalista y egoísta enmascarado en un remedo de justicia provocado, quién sabe, si por conflictos no resueltos

${ }^{35}$ De Cuenca, Luis Alberto, El héroe y sus máscaras, Madrid: Biblioteca Mondadori, 1991, p. 19.

${ }^{36} \mathrm{Mr}$. Smith goes to Washington [Caballero sin esapda], dir. Frank Capra, act. James Stewart, Columbia Pictures, 1939.

${ }^{37}$ Batman: El regreso del caballero oscuro, Frank Miller y Klaus Janson, 4a edición. Barcelona: ECC Ediciones, 2016.

${ }^{38}$ Luther KIng, Martin, El clarín de la conciencia, 2a edición, Barcelona: Aymá S.A. Editora, 1973, p. 106. 
(tal es el caso del Batman de Frank Miller, un ejemplo de perfil psicológico al límite por traumas no superados). Estas ideas se ven reflejadas en la reinterpretación del cinematográfico Batman de esta última década. Concretamente, en la película Batman: El caballero oscuro. ${ }^{39}$ Allí, el rol del policía Jim Gordon (interpretado por el actor Gary Oldman), uno de los escasos representantes honestos que aparecen en la película y una suerte de David contra el Goliat que simboliza la corrupta ciudad de Gotham, sugiere una interesante reflexión final sobre las consecuencias de un justiciero (Batman) aceptado casi inconscientemente por la sociedad. Se trata de una conversación que mantiene el policía Jim Gordon con su propio hijo tras ser éste secuestrado a raíz de un plan del malvado Joker y rescatado al final de la película por Batman, quien en un epílogo épico huye en su batmoto convertido ya en un caballero oscuro:

—¿Por qué huye, papá?

- Porque tenemos que perseguirle.

- Pero si no ha hecho nada malo.

- Porque es el héroe que Gotham se merece, pero no el que necesita ahora mismo. Así que lo perseguiremos porque él puede resistirlo. Porque no es un héroe. Es un guardián silencioso, un protector vigilante. Un caballero oscuro.

Por épico que pueda parecer el final de la película (más bien un final made in Hollywood), el mensaje es, cuanto menos, perturbador. El comisario Gordon y con él la ciudad de Gotham como "su protegida" están aceptando y justificando a Batman, y por lo tanto esa visión casi romántica del justiciero. La legalidad se va a mantener pero a costa de mentiras. ${ }^{40}$ Son curiosas las palabras porque el rol del policía asume que la ciudad, una vez traspasada la frágil línea de la justicia, tiene un tipo de héroe que no sólo bordea la ley sino que la sobrepasa. Una nueva situación no sobrevenida sino aceptada tácitamente por la misma sociedad que en consecuencia se enfrenta al dilema de legitimar a un justiciero que, en palabras del policía, la ciudad se merece. Más bien como una especie de castigo que como un premio. Un justiciero, no un paladín de la justicia, que actúa como un revulsivo en un momento concreto, puntual y probablemente justificado por una realidad que supera lo razonable. Pero las consecuencias de su llegada pueden ser a medio o largo plazo especialmente negativas, si no devastadoras, para el tejido moral de una sociedad. Esto es debido a que si las manifestaciones de un justiciero son aclamadas y aplaudidas por la

${ }^{39}$ The Dark Knight [Batman: El caballero oscuro], dir. Christopher Nolan, act. Christian Bale y otros, Warner Bros. Pictures, 2008.

${ }^{40}$ No obstante, cabe señalar que en la tercera y última entrega de las aventuras de este cinematográfico Batman, se procede a restaurar su honor y salen a la luz los motivos que produjeron su huida y la persecución policial a la que es sometido. 
ciudadanía con una disposición acrítica, luego no puede causar extrañeza que ese "monstruo" al que se le ha sacado de la jaula no quiera volver a entrar en ella. ¿De qué manera se podrá controlar al justiciero cuando éste se encuentra a sí mismo legitimado para hacer aquello que en el acervo popular no es valorado sino como mera venganza?

\section{REFLEXIÓN FINAL: ¿QUÉ CLASE DE HÉROE? ¿NECESITAMOS HÉROES?}

Finalmente, se podría valorar si la idoneidad de un justiciero aporta más beneficios que desventajas a una comunidad. La realidad es que en la medida en que se busquen salidas que justifiquen una acción fuera de la ley estaremos poniendo las bases para el advenimiento de un modelo de Estado que será un remedo de democracia, pero no una democracia real. Es por ello que cobra tanta importancia en este contexto la "recomendación" de Platón en su obra Las leyes cuando afirma que, "es imprescindible que los hombres tengan leyes y que se sometan a ellas; sin lo cual en nada se diferenciarían de las bestias más feroces". ${ }^{41}$

La conclusión es, por tanto evidente. Para Weber el Estado ostenta el monopolio de la violencia legítima. Un justiciero sería un ejemplo de "detentador" de esa atribución que en exclusiva se arroga el Estado. Las leyes se hacen necesarias para la convivencia. Leyes justas; claro está. Lo contrario puede llevar a un fuera de la ley, a quien la bordea peligrosamente o, en el peor de los casos, la interpreta torticera e interesadamente. El verdadero héroe será el responsable de restablecer el orden y servir como acicate para una sociedad cuyos principios morales puedan haber sido menoscabados o incluso sustituidos por otros no deseados. Son en tales circunstancias, como las aquí expuestas, en las que se precisa un verdadero héroe. No un justiciero. Un adalid de la justicia, un referente que pueda ser lo suficientemente inspirador como para recordar algo tan importante como que no se deberían tomar atajos en el camino de la justicia. Nada más y nada menos.

Para ir finalizando, con respecto a la idea del héroe, una última reflexión para dejar abierto el debate. La inspiración suele ser una de las más recurrentes características inherentes al héroe. Como aprecia Castillo "los héroes han sido siempre ejemplos de comportamiento para las nuevas generaciones, a las que muestran su capacidad de entrega, de sacrificio y de superación personal" ${ }^{42} \mathrm{Sin}$ tener que estar necesariamente en desacuerdo con esta idea, podría también plantearse que el modelo a seguir considerado como auténticamente inspirador debería, sencillamente, no existir. Así de simple. La mayoría de las personas

${ }^{41}$ Platón, Las leyes, libro IX, 875a, 2a edición, Madrid: Alianza Editorial, 2014, p. 496-7.

${ }^{42}$ Castillo, Gerardo, La forja del héroe, Madrid: Ediciones Rialp, 2013, p. 9. 
podemos en un momento determinado realizar actos que bien podrían ser considerados como heroicos, como dignos de ser imitados. Episodios de la vida cotidiana que alejados del "glamour" de los héroes con capa nos acercan más a la realidad y que reflejan, probablemente mejor, la idea más objetiva y exenta de romanticismo que se le puede atribuir a un héroe. Un héroe de lo cotidiano. Como apuntan Loeb y Morris:

Entre los héroes que viven y trabajan a nuestro alrededor día a día se cuentan tanto hombres como mujeres, bomberos, policías, médicos, enfermeros, maestros. [...] Luchan por la salud, la seguridad, la excelencia y el crecimiento humanos. Son guerreros de la vida cotidiana cuyos sacrificios y acciones nobles nos benefician a todos. Sin embargo, no solemos considerar héroes a estas personas. ${ }^{43}$

Tal vez el modelo que se persigue no debería estar alejado de la realidad. Tal vez en lugar de buscar figuras inspiradoras convertidas en estándares morales (no siempre fácilmente alcanzables) sería más realista aceptar unos héroes de carne y hueso, gente normal en situaciones normales que desempeñan su tarea lo mejor posible. Según esta visión, "un héroe es cualquier individuo que realice bien su trabajo y haga una contribución mínima al bienestar público" ${ }^{44}$ Baste una imagen para poner de relieve esta última idea. En el número correspondiente a diciembre de 2001, en el cómic The Amazing Spider-man ${ }^{45}$ (Fig. 1) se hizo un sentido homenaje a las víctimas del brutal atentado de las Torres gemelas de Nueva York. En la historia que se presenta en el cómic se ve una clara apuesta por la figura del héroe ordinario. En una situación inimaginable, los superhéroes han sido incapaces de prevenir el ataque. Las consecuencias se reflejan a lo largo de toda la historia del citado cómic. Pero tal vez una de las imágenes con mayor fuerza es la vińeta que cierra el número y en la que se ven en un segundo plano a los superhéroes y en primer término a los que se convirtieron involuntariamente en los verdaderos héroes de esos días: policías, bomberos, médicos, gente anónima que dieron lo mejor de ellos mismos y que encarnaron de manera natural y espontánea pero desinteresadamente los valores que se esperan de un auténtico héroe no de un justiciero.

${ }^{43}$ Loeb, J. y Morris T., Héroes y superhéroes en Los superhéroes y la filosofía, Barcelona: Blackie Books, 2010, p. 36.

${ }^{44}$ Hook, Sidney. El héroe en la historia, Buenos Aires: Galatea - Nueva Visión, 1943, p. 169.

${ }^{45}$ Straczynsky, J. M. y Romita Jr., John, The Amazing Spider-man (Vol.2) \#36. Spiderman: los imprescindibles. Barcelona: Panini Comics, 2007. 


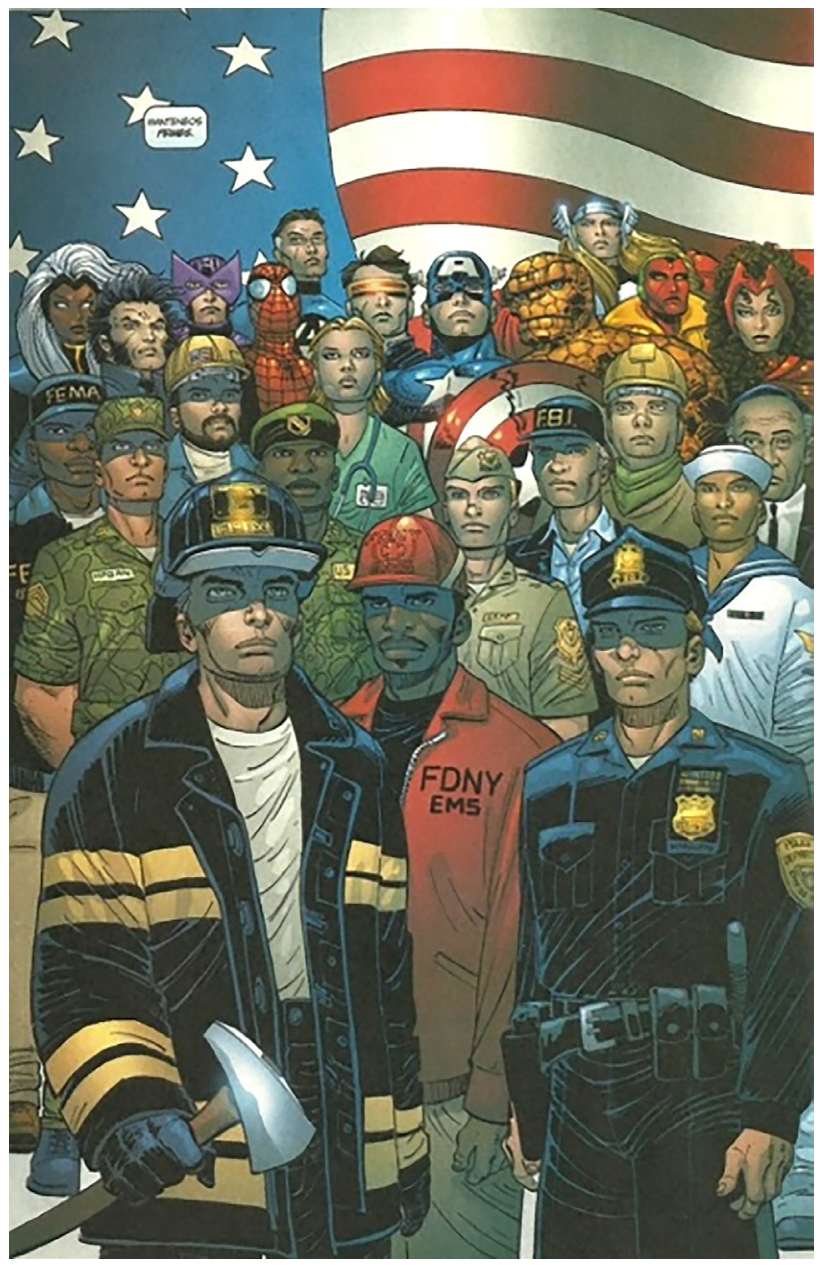

FIG. 1. Amazing Spider-Man (Vol. 2) \#36

"Un héroe no es más valiente que un hombre corriente, pero lo es cinco minutos más" Ralph Waldo Emerson 


\section{BIBLIOGRAFÍA}

Arendt, H. 2009, Los orígenes del totalitarismo, Madrid: Alianza Editorial.

BauzÁ, H. F. 2007, El mito del héroe: Morfología y semántica de la figura heroica, Buenos Aires: Fondo de Cultura Económica.

Castillo, G. 201 3, La forja del héroe, Madrid: Ediciones Rialp.

De Cuenca, L. A. I991, El héroe y sus máscaras, Madrid: Biblioteca Mondadori.

Eco, U. 2016, Apocalípticos e integrados, Barcelona: De Bolsillo.

Eco, U. 2016, El superhombre de masas, Barcelona: De Bolsillo.

Hobbes, T. 1983, Leviatan, Madrid: Editorial Sarpe.

Ноок, S. 1943, El héroe en la historia, Buenos Aires: Galatea-Nueva Visión.

Howe, S. 20 I 3, Marvel Comics: La historia jamás contada, Girona: Panini Comics.

Luther King, M. I973, El clarín de la conciencia, Barcelona: Aymá S.A.

Maquiavelo, N. 1995, El principe, Madrid: Alianza Editorial.

Montesquieu 2002, Del espiritu de las leyes, Madrid: Tecnos,.

Morris M.; Morris T. (ed.) 20 io, Los superhéroes y la filosofía, Barcelona: Blackie Books.

Nietzsche, F. 200 i, La genealogía de la moral, Madrid: Alianza Editorial.

Nietzsche, F. 2007, Más allá del bien y del mal, Madrid: Alianza Editorial.

Platón 20I 4, Las Leyes, Madrid: Alianza Editorial.

Savater, F. I983, La tarea del héroe, Madrid: Taurus.

Thoreau, H. D. 2004, Desobediencia civil, Madrid: Tecnos.

Weber, M. 20 I 5, El político y el cientifico, Madrid: Alianza Editorial.

\section{WEBGRAFÍA}

Martínez Ahrens, J. 20 i 6, "Elmisterio del justiciero del autobús sacude México": http:// internacional.elpais.com/internacional/2016/11/04/mexico/1478223570 _248293.html. El País, 7-11 nov. 
NOVELAS GRÁFICAS/CÓMICS

Conway, G.; Andru, R. 2016, The Amazing Spider-Man \#129 en Marvel Gold. El asombroso Spider-Man 6. La saga del clon, Girona: Panini Comics.

Millar, M.; McNiven, S. 2oro, Civil War, Barcelona: Marvel Deluxe. Panini Comics.

Miller, F.; Janson, K. 20I6, Batman: El regreso del caballero oscuro, Barcelona: ECC Ediciones.

Moore, A.; Lloyd, D. 201 5, V de Vendetta, Barcelona: ECC Ediciones.

Straczynsky, J. M.; Romita Jr., J. 2007, The Amazing Spider-Man (Vol.2) \#36.

Spider-man: Los imprescindibles, Barcelona: Panini Comics.

Filmografía

Death Wish [El justiciero de la ciudad], dir. Michael Winner, Paramount Pictures, I974.

Mr. Smith goes to Washington [Caballero sin espada], dir. Frank CAPra, Columbia Pictures, 1939.

The Dark Knight [Batman: El caballero oscuro], dir. Christopher Nolan, Warner Bros. Pictures, 2008.

\section{DiCCIONARIOS Y MANUALES}

Diccionario de la Real Academia Española, Madrid: Editorial Espasa-Calpe, I995. 

Brúixola filosòfica 

QUADERNS DE FILOSOFIA VOL. VI NÚM. 2 (20I9): 9 I-I 27

eISSN: 234I-3042 DOI: I0.7203/QFIA. 6.2.I6055

JOAN GIMENO-SIMÓ

Universitat de València

\section{Semàntica i pragmàtica, contingut i context}

Rebut: . Acceptat:

Resum: Aquest article té com a objectiu resumir els punts principals del debat sobre la divisió entre semàntica i pragmàtica. S'hi expliquen les tres principals postures dins la disputa i s'hi proporciona un esquema general per determinar quines teories encaixen a cadascuna d'elles. L'article conclou amb una breu discussió sobre la naturalesa de la noció de contingut i el seu rol al debat.

Abstract: The aim of this paper is to summarize the main lines of the debate about the semantics-pragmatics divide. The three main contenders in the dispute are explained, and a general schema for fitting theories into each of them is provided. This article concludes with a brief discussion on the nature of the notion of content and its role in this debate.

Paraules clau: minimisme, contextualisme, relativisme, contingut explícit.

Keywords: minimalism, contextualism, relativism, explicit content.

T A semàntica estudia el significAt lingüístic. La pragmàtica, per la L seua banda, sol ser caracteritzada com l'estudi de temes com ara els usos del llenguatge o els efectes del context sobre el significat, entre d'altres. Aquestes caracteritzacions són encara molt imprecises, però fan palès que estem tractant amb dues disciplines que comparteixen en gran mesura l'objecte del seu estudi, i que en conseqüència se solapen l'una a l'altra ben sovint. Aquest assaig està dedicat a estudiar aquest solapament i les postures que hom ha pres al respecte: repassarem les principals propostes que s'han plantejat per traçar la línia divisòria entre la semàntica i la pragmàtica, si és que se’n pot traçar cap, i provarem d'oferir un marc general per copsar les diverses maneres d'establir aquesta distinció. Com vorem, aquestes propostes depenen en última instància 
de la concepció que hom tinga d'aquests dos camps d'estudi, així com de conceptes clau com ara "significat" o "context".

Entre les postures divergents que han pres part en aquest debat les més conegudes i comunament acceptades son el minimisme, el contextualisme i el relativisme; les explicarem i detallarem a les tres primeres seccions. Les diferències que hi ha entre aquestes postures són a vegades nominals, però sovint amaguen discrepàncies insalvables en la manera d'entendre allò que volen explicar, fins al punt de discrepar pel que fa a les dades de què una teoria semàntica ha de fer-se càrrec. Val a dir, però, que cadascuna d'aquestes tres categories generals aixopluga tot un ventall de teories i de posicions intermèdies; a més, no és infreqüent que hom adopte postures diferents depenent del tipus d'expressions que estiga tractant —així doncs, sovint l'adopció de l'una o de l'altra per part d'un autor no reflecteix necessàriament una manera de concebre la separació entre semàntica i pragmàtica- .

En aquest assaig oferiré un marc general per entendre quan una postura compta com a minimista, contextualista o relativista (secció primera), i més endavant passaré a discutir-les i a fer-ne una comparativa, tot citant quins tipus d'evidència s'ha fet servir per argumentar-hi a favor i discutint com aplicar-les a casos concrets (seccions segona i tercera). Conclouré amb una breu discussió sobre la naturalesa de la noció de contingut i la seua relació amb el debat que ens ocupa (secció quarta).

\section{Context I ALlò ASSEverat}

La classificació d'una postura com a minimista, contextualista o relativista depèn, en essència, de la importància que aquesta atribuïsca a cadascuna de les dues tasques fonamentals que el context pot dur a terme. D'ençà de l'obra d'autors com ara David Kaplan (I977) i David Lewis (I980) ha esdevingut estàndard atribuir al context dos rols diferents, una dualitat ja reconeguda pel pare de la semàntica contemporània, Richard Montague (1970, 379). Seguint la terminologia de John MacFarlane (2003B; 2005) podem classificar aquest doble paper així: un rol post-semàntic consistent a determinar a quin aspecte de la realitat es correspon el contingut d'una expressió lingüística, i un rol semàntic consistent a determinar quin contingut ha estat asseverat. En termes generals, podem dir que una postura compta com a contextualista si atorga al context una funció semàntica molt important, mentre que les postures relativistes acostumen a donar més importància al paper post-semàntic. Les postures minimistes, en canvi, es caracteritzen per reconèixer un contingut mínim que no depèn del context en cap d'aquestes dues maneres. Vegem en què consisteix cadascun d'aquests rols. 
Hui dia és gairebé un truisme en filosofia del llenguatge que l'extensió d'una expressió (el conjunt d'objectes que hi cauen a sota) depèn d'alguna mena de paràmetre extralingüístic: la persona denotada per un ús de l'expressió "el quaranta-cinquè president dels Estats Units" dependrà de qui haja arribat a ocupar el despatx oval de la Casa Blanca en un determinat moment històric. Tanmateix, no sembla plausible que una propietat purament lingüística com és el significat d'una expressió puga variar en funció del resultat d'unes eleccions nord-americanes. El que açò vol dir és que el significat d'una expressió no ha de ser identificat amb la seua extensió, sinó més aviat amb una regla per determinar-ne l'extensió d'acord amb diverses situacions, tant de reals com de contrafactuals ${ }^{1}$. En aquesta mena de semàntiques, el significat cal identificar-lo amb una intensió: una regla (o, més acuradament, una funció) que determina l'extensió d'una expressió d'acord amb algun paràmetre extralingüístic, ja siguen aquests descripcions d'estats (CARNAP I 947), situacions (BARWISE i Perry I983) o, el més habitual, mons possibles (KRIPKE I 972).

Vet ací, doncs, una primera qüestió on el context esdevé rellevant: la de determinar l'extensió d'una expressió, ço és, aquell aspecte de la realitat a què es correspon la informació transmesa per aquesta. En el món real, "el quarantacinquè president dels Estats Units" es correspon amb Donald Trump, però hi ha situacions alternatives on denota Hillary Clinton; les expressions "animal amb ronyons" i "animal amb cor" tenen la mateixa extensió al món real, però reben valors distints si són avaluats en un món alternatiu. En última instància, la veritat o falsedat de la proposició expressada per un enunciat (és a dir, la veritat o falsedat d'allò dit $\mathrm{o}$ allò asseverat) dependrà del món possible, situació o descripció d'estat en què estiguem avaluant-la: l'enunciat "el quaranta-cinquè president dels Estats Units és un home" assevera una proposició que podria haver estat falsa si els esdeveniments històrics hagueren ocorregut altrament. Així doncs, si identifiquem la informació transmesa per una expressió amb la intensió d'aquesta, un rol del context consisteix a determinar a quin aspecte de la realitat es correspon aquesta informació. Aquest és, per tant, un rol post-semàntic: serveix per avaluar si allò asseverat és vertader o fals.

Tanmateix, aquest no és l'únic rol que el context pot exercir. L'obra dels autors esmentats més amunt ha fet palés que el paper que juga el context és doble: no només pot servir per avaluar si allò asseverat és vertader o fals, sinó

${ }^{1}$ Aquesta idea ja es troba latent a l'obra de Gottlob Frege (I 892), i eventualment va cristal-litzar en el desenvolupament de les semàntiques intensionals, introduïdes per Alonzo Church (195I) i Rudolf Carnap (I947). També és molt important l'obra de Marcus (I946) i Kripke (I959; I963A; I963в). 
també per determinar què és allò que es diu, ço és, per determinar la intensió que una expressió rep quan és emesa en un determinat context. Considereu enunciats com els següents:

(1) Jo he estat batlle de Morella

(2) Ella vol viatjar a la Xina

(3) Demà plourà

Imaginem dues emissions de l'enunciat (1), la primera per Ximo Puig i la segona per Blasco Ibáńez. El primer ha dit una cosa que és certa, i el segon una de falsa; en la mesura que cada emissió determina unes condicions de veritat distintes, sembla adient de dir que han asseverat proposicions diferents. En termes de proposicions estructurades russellianes, podem representar allò dit per cadascuna de les dues emissions d'(1) així:

(1a) <Ximo Puig, ésser batlle de Morella>

(1b) <Blasco Ibáńez, ésser batlle de Morella $>$

Per descomptat, (1a) i (1b) no són vertaderes en els mateixos mons possibles, ni en les mateixes situacions o descripcions d'estats: es tracta de dues proposicions (intensions) distintes, les condicions de veritat de les quals difereixen. Tanmateix, l'enunciat que hom ha fet servir per expressar-les ha estat el mateix, i amb els enunciats (2) i (3) ocorre una cosa semblant: la proposició que expressen variarà, respectivament, segons la persona que estiguem assenyalant i segons el dia d'emissió.

Allò característic d'aquests enunciats és que contenen expressions díctiques, ço és, mots el referent dels quals varia segons la circumstància d'emissió: "jo", "demà", "ell", "acî". El rol que juga el context en determinar el contingut d'aquests enunciats és ben diferent del que hem descrit més amunt: no es tracta d'avaluar si allò asseverat és vertader o fals, sinó més aviat de determinar què és allò asseverat — si hom vol avaluar si la informació transmesa és vertadera o falsa, primer cal esbrinar quina és aquesta informació-. Les condicions de veritat del que es diu en emetre els enunciats (1-3) variaran segons el context en què hom els emeta; per tant, podem dir que el context no juga ací un rol merament post-semàntic, consistent a determinar si allò asseverat és vertader o fals, sinó plenament semàntic, car és imprescindible per elucidar què ha estat expressat.

Així doncs, a la literatura sobre semàntica i pragmàtica hom acostuma a distingir entre el context d'emissió i el context d'avaluació. Una expressió feta servir en un context d'emissió particular té un contingut determinat; si és un enunciat, expressa una proposició. Aquest contingut o proposició, al seu torn, és un objecte abstracte amb propietats intensionals: és una constructe que pot correspondre's amb coses diferents, o ser vertader o fals, depenent del context o circumstàncies en què estiguem avaluant-lo. La imatge bàsica és la següent 
(adaptat de Schaffer 2008; Santorio 20 i 2; Westerståhl 20 i 2; i Rabern i BALL 20I9):

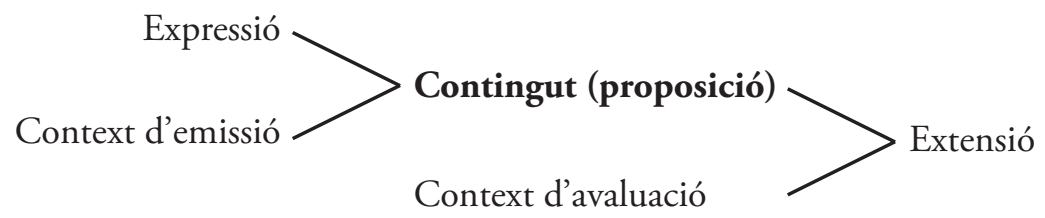

Un caveat que cal tindre present és que aquests contexts no han de ser concebuts com a situacions reals: són més aviat eines abstractes que el teòric fa servir per tal d'explicar tota mena de fenòmens lingüístics (vegeu BALL 20 I 7 per a una discussió). Açò vol dir que la seua relació amb la realitat no és tan directa com puga semblar, i que la seua composició exacta pot variar depenent de la teoria que estiguem defensant i dels fenòmens que voldrem modelar. Allò comú és tractar el context d'avaluació senzillament com un món possible, però molts autors hi incorporen paràmetres addicionals; Kaplan (I977), per exemple, pensava en els contexts d'avaluació, que ell anomenava circumstàncies, com a parells consistents en un món i un instant de temps, de manera que allò dit seria vertader o fals depenent no només de com siga el món sinó també del moment particular en què estiguem avaluant-ho ${ }^{2}$. De la mateixa manera, hom ha proposat tot un seguit de paràmetres que poden pertànyer al context d'emissió: parlants, oïdors, llocs, instants de temps o estàndards de precisió, entre d'altres, semblen rellevants a l'hora de determinar quina proposició ha estat expressada.

Tenint aquesta imatge bàsica en ment es pot formular un criteri inicial, que més endavant matisarem, per distingir les tres postures esmentades més amunt. El minimisme, també conegut com a "tradicionalisme", "invariantisme" o "literalisme", defensa que el nombre d'expressions que depenen del context d'emissió és mínim, i que a més estan sintàcticament marcades: es tracta dels díctics, i potser també altres elements amb funció gramatical, com la morfologia verbal. Dit altrament, un enunciat que no continga cap díctic expressa la mateixa proposició - té les mateixes condicions de veritat - en tots els contexts d'emissió. El principal adversari del minimisme és el contextualisme, que defensa exactament el contrari: la dependència contextual va molt més enllà dels díctics i afecta expressions de tota mena, de manera que és ben possible fer servir un enunciat no-díctic, no-el-líptic i no-ambigu per expressar proposicions distintes depenent del

\footnotetext{
${ }^{2}$ Aquesta postura sol anomenar-se "temporalisme", per contraposició a l'eternisme, que concep les proposicions com a quelcom que ja incorpora un temps i que per tant no varien depenent de en quin instant les avaluem.
} 
context d'emissió; aquesta dependència contextual generalitzada es deu a una intromissió de processos de caire pragmàtic dins del processament sintàctic i semàntic, fet que impedeix concebre la semàntica com una disciplina autònoma. El relativisme, per la seua banda, planteja una mena de tercera via, intermèdia entre les altres dues postures: com vorem, accepta moltes de les dades proposades tant per minimistes com per contextualistes, i es diferencia d'aquests últims perquè, en comptes d'explicar les dades problemàtiques apel.lant a una diferència en les proposicions expressades, prova d'acomodarles afegint més paràmetres al context d'avaluació, de manera que la veritat d'un enunciat (no allò que expressa) és relativa a tot un seguit de paràmetres que van més enllà d'un món possible i que els tradicionalistes normalment no acceptarien.

Un xicotet exemple pot ajudar a copsar la diferència entre aquestes tres postures. Imaginem que tot just després d'un congrés de filosofia té lloc un sopar, i hom hi emet l'enunciat $(4)^{3}$ :

(4) Tots els epistemòlegs estan prenent cafè

Deixant de banda la morfologia verbal, que ací resulta irrellevant, (4) no conté cap díctic; açò vol dir que, d'acord amb el minimisme, aquest enunciat expressa sempre la mateixa proposició, independentment del context en què s'emeta. Aquesta idea pot resultar una mica contraintuïtiva, car allò expressat literalment per aquest enunciat no és una proposició sobre els epistemòlegs que hi ha al sopar, sinó sobre tots els epistemòlegs de l'univers, i per tant diu quelcom que és òbviament fals. Així doncs, hi ha una discrepància entre el significat literal de (4) i el que el parlant volia expressar mitjançant l'emissió d'aquesta, fet que els minimistes acostumen a explicar tot apel-lant a fenòmens de caire pragmàtic, normalment subscrivint una distinció estricta entre allò dit i allò implicat, i tot dient que els judicis dels parlants no sempre capturen allò literalment expressat. Els contextualistes, per la seua banda, adoptarien tot un seguit d'estratègies per argumentar que (4), en el context en què ha estat usada, expressa una proposició més o menys equivalent a "tots els epistemòlegs d'aquest sopar estan prenent cafè". Els relativistes, en canvi, concedirien que (4) expressa el mateix independentment del context en què siga enunciada, però dirien que allò expressat no és quelcom vertader o fals de manera absoluta sinó en relació amb un seguit de paràmetres que inclouen no només un món possible sinó també d'altres, com ara un domini de quantificació, un instant de temps, etc. Allò que (4) expressa, doncs, no serà vertader depenent només de com siga el món, sinó també, per exemple, del conjunt d'individus rellevants en què calga fixar-s'hi.

\footnotetext{
${ }^{3}$ Per a una discussió general sobre el debat entre contextualisme, relativisme i minimisme en el context dels dominis de quantificació, vegeu Stojanovic (2008).
} 
Aquestes estratègies poden aplicar-se a tot un ventall de casos, i l'adopció de l'una o de l'altra té conseqüències en diversos temes, com ara la distinció entre la mentida i el mer engany o la discussió sobre la dependència contextual del verb "conèixer", ja clàssica en epistemologia ${ }^{4}$. En les dues seccions següents examinarem les principals dades que s'han fet servir per motivar cadascuna d'aquestes aproximacions a la semàntica i la pragmàtica, i explicarem en profunditat els seus postulats bàsics més enllà de l'esquema general - i a vegades no del tot acurat— que hem proporcionat més amunt.

\section{Minimisme i conteXtualisme}

El debat entre el minimisme i el contextualisme pot considerar-se com una continuació contemporània del debat clàssic entre les aproximacions formals a l'estudi del llenguatge i les teories basades en l'ús. La tradició formalista té les seues arrels a l'obra de filòsofs com ara Gottlob Frege, Bertrand Russell, Rudolf Carnap o Ludwig Wittgenstein a la primera etapa del seu pensament, mentre la segona l'encapçalen figures com el segon Wittgenstein i els representants de l'escola d'Òxford, notablement John Austin i Peter Strawon. El relativisme és una postura d'aparició més recent $\mathrm{i}$, malgrat que es pot considerar com una mena de síntesi entre les altres dues, també pot ser vista com una vessant del formalisme que es pren seriosament les dades oferides pel contextualisme i prova d'acomodar-les sense haver de renunciar als mètodes tradicionals. Al llarg d'aquesta secció i de la següent explicarem i confrontarem aquestes tres postures.

Amb excepcions, el minimisme es caracteritza per defensar l'ús d'eines formals, normalment provinents de la teoria de models $^{5}$, per estudiar la semàntica del llenguatge natural. La idea és associar cada element lèxic amb una entitat abstracta, el seu significat, de manera que el significat de les expressions més complexes quede determinat pel significat dels elements més simples que les composen i per la manera com aquests estan ordenats -el que normalment hom anomena "composicionalitat"-. El significat lingüístic és vist com a formalment tractable en tant que la dependència contextual és mínima: al parer

${ }^{4}$ El debat és sobre si el verb "conèixer" depèn o no del context d'emissió. Una defensa clàssica del contextualisme en epistemologia és Williams (I99I); vegeu també Williamson (2005) per a una defensa de l'invariantisme i el volum d'Ichiakwa (2017) per a una visió general del debat. El mot "contextualisme" va sorgir precisament arran de la disputa en epistemologia, i no va ser fins més endavant que Recanati (2004) el va adaptar per al debat que ens ocupa.

${ }^{5}$ En realitat és enganyós parlar de models en semàntica formal, ja que la relativització a models sol ser omesa per irrellevant; d'entrada, n'hi ha prou d'associar cada expressió amb un objecte conjuntista. Vegeu Glanzberg (2014). 
dels minimistes, com ja hem esmentat, les úniques expressions el contingut de les quals pot variar segons el context d'emissió són els díctics, i llur variabilitat pot ser tractada de manera més o menys sistemàtica mitjançant regles bastant simples ("jo" refereix al parlant, "ara" al moment en què hom parla, etc.).

Un exemple de minimisme molt simple, i que ens servirà per il.lustrar aquesta idea, ens el proporcionen els projectes davidsonians (DAVIDSON 1967), que tenen com a objectiu obtindre una manera sistemàtica d'associar cada enunciat del llenguatge estudiat amb la seua traducció al metallenguatge, generant així enunciats veritatius amb la forma següent:

(5a) L'enunciat 'La neu és blanca' és vertader si i sols si la neu és blanca

(5b) L’enunciat 'La neu és blanca i freda' és vertader si i sols si la neu és blanca i la neu és freda

(5c) L'enunciat 'Snow is white' és vertader si i sols si la neu és blanca

Aquesta traducció acostuma a poder fer-se mitjançant un enunciat homòfon del metallenguatge, un procediment que en la majoria de casos resulta trivial: només cal llevar-ne les cometes ${ }^{6}$. Hi ha, però, enunciats per als quals aquesta traducció homòfona no està disponible ni resulta tan trivial com sembla, fet que per als davidsonians és indicatiu que ens trobem davant d'un mot el contingut del qual depèn del context d'emissió. Aquest és el cas dels enunciats amb díctics:

(6a) 'Jo sóc brasiler' és vertader si i sols jo sóc brasiler

És correcte un enunciat veritatiu com (6a)? Hi ha una asimetria important entre (6a) i (5a): aquest últim prediu que cada ús de l'enunciat 'La neu és blanca' serà vertader si al món s'acompleix la condició que la neu és blanca, però la predicció de (6a) és que cada emissió de 'jo sóc brasiler' serà vertadera només en cas que Joan siga brasiler, en tant que és Joan mateix qui ha estipulat (6a). Açò és òbviament erroni: Lula da Silva hauria de poder fer servir aquest enunciat per dir quelcom de vertader. Així doncs, la regla que ens cal és més aviat així:

(6b) 'Jo sóc brasiler' és vertader si i sols si l'objecte $a$ és brasiler, on $a$ és el parlant

${ }^{6}$ Hem fet servir una teoria davidsoniana perquè resulta facil il-lustrar-hi el minimisme; hi ha, però, quelcom d'immediatament sospitós en aquesta mena de teories: quan hom assumeix la tasca d'oferir una teoria de com funciona el llenguatge, o qualsevol altre fenomen, és dubtós que les explicacions hagen de ser donades en llenguatge natural. Les teories científiques poden, en els seus inicis, fer servir variants tècniques del vocabulari quotidià, però aquesta mena de vocabulari no és el més adient i eventualment ha de ser deixat enrere (el mot "memòria" que fan servir els psicòlegs pot estar relacionat amb la seua contrapart quotidiana, però refereix a una construcció teòrica que permet dur a terme prediccions i explicar fets). Si fem servir el llenguatge objecte com a metallenguatge, hi ha el risc de caure en la il·lusió d'haver explicat el problema quan senzillament l'hem desplaçat o, pitjor encara, trivialitzat (GLANZBerg 20I4; YALCIN 20I8). 
Açò vol dir que no sempre és possible de procedir mitjançant traduccions homòfones al metallenguatge: per al cas dels díctics no n’hi ha prou amb llevar les cometes. Aquesta asimetria es veu reflectida en diversos fenòmens que, com vorem més avall, han estat considerats com els casos més favorables al minimisme: el-lipsi, anàfora, analiticitat, cancel-labilitat $\mathrm{i}$, fins a cert punt, discurs indirecte. Per als minimistes aquesta asimetria, o una que puga ser formulada de manera semblant, mostra que estem tractant amb una expressió el contingut de la qual depèn del context d'emissió.

Una de les dues obres de referència del minimisme, Insensitive Semantics, de Herman Cappelen i Ernst Lepore (2005), presenta una aproximació davidsoniana a l'estudi del llenguatge. Tanmateix, no tota postura minimista és davidsoniana; l'obra que dóna nom a aquest corrent, Minimal Semantics, d'Emma Borg (2004), presenta una aproximació més estàndard, on les expressions lingüístiques no són associades a la seua contrapart en el metallenguatge sinó a objectes formals que en modelen el significat; aquest enfocament s'acosta més als procediments habituals per a l'estudi d'altres aspectes del llenguatge, com ara la sintaxi a la tradició generativista, i de fet una de les motivacions de Borg és la de fer compatible la semàntica amb una teoria modular del processament lingüístic. Altres representants del tradicionalisme són Scott Soames (2002), Stefano Predelli (2005A; 2005B ${ }^{7}$ i, fins a cert punt, Kent Bach (200I) i Jennifer Saul (2013). Més enllà de les discrepàncies, tots aquests autors comparteixen una tesi fonamental que permet de classificar-los com a minimistes, i que podem formular així:

MINIMISME: el rol del context en la determinació del contingut explícit d'una emissió es limita a aportar allò necessari per tal d'obtindre quelcom que pot ser avaluat com a vertader o fals.

La idea és que l'enunciat mateix disposa d'uns buits que cal emplenar mitjançant informació contextual per tal d'obtenir una proposició; un cop dut a terme aquest procés, la resta d'efectes del context són relegats a la pragmàtica i no tenen cap mena d'efecte semàntic. Aquest procediment ha estat anomenat saturació (ReCanati 2004, 7-10) i sol ser caracteritzat com una tasca que va de baix cap a dalt ("bottom-up"): es tracta d'un procés obligatori, requerit per l'enunciat mateix i, en particular, per la seua sintaxi: el paper del context en la determinació del significat oracional es limita a fixar els referents dels díctics i a resoldre ambigüitats, anàfores i el.lipsis. Un cop açò s'ha dut a terme, el context deixa d'exercir cap mena paper semàntic, tot i que encara pot servir per determinar informació transmesa a nivell implícit. Una formulació alternativa de la tesi fonamental del minimisme podria ser la següent:

${ }^{7}$ La postura de Predelli (2005A; 2005B) és sovint classificada com a relativista; vegeu-ne la discussió més avall. 
MINIMISME*: la dependència contextual del contingut explícit d'una emissió està sintàcticament marcada.

Aquesta caracterització no és equivalent a la que hem proporcionat més amunt, i hi ha minimistes que hi estarien en desacord. Allò important, però, és que els minimistes no neguen la importància del context en determinar la informació transmesa, sinó només a l'hora de determinar el contingut literal transmès per un enunciat, ço és, allò explícitament asseverat. Quan hom parla transmet informació que va molt més enllà del que les seues paraules literalment signifiquen, un fenomen que es fa ben palès quan pensem figures retòriques com ara la ironia o la metàfora però que en realitat és gairebé omnipresent: la informació que hom comunica mitjançant una emissió variarà depenent de factors tan diversos com la informació prèvia de què disposen els participants en la conversa, les seues intencions, el to de veu o fins i tot l'accent. Res d'açò, però, no té efectes sobre el significat literal d'un enunciat. En general, els minimistes s'adhereixen a la distinció griceana entre allò asseverat i allò implicat (GRICE 196I; I975): si un matí que no he esmorzat m'adrece als meus companys de feina tot dient-los "em morc de gana", el contingut literal de la meua emissió és fals, tot i que a nivell implícit puc estar transmetent-los-hi quelcom de vertader.

Els contextualistes, en canvi, no veuen gaire clara la idea de significat literal independent d'allò que el parlant vullga transmetre (RECANATI 200I; 2004). La tesi fonamental del contextualisme consisteix a dir que l'efecte dels processos pragmàtics sobre allò asseverat explícitament per una emissió va més enllà de la saturació: aquest procediment de caràcter obligatori no proporciona una proposició dreta i feta, sinó que els participants en la conversa encara poden dur a terme, addicionalment, un procés de dalt cap a avall ("top-down"), no obligatori, on enriqueixen lliurement l'enunciat fins assolir un contingut que té sentit contextualment. Vegem-ne un exemple:

(7) Aquest llibre és difícil

Un minimista diria que tot el que cal per tal d'obtenir la proposició expressada per (7) és determinar quin és el referent del demostratiu "aquest llibre". El contextualista, però, aniria més lluny, i diria encara és possible enriquir aquest contingut fins assolir un proposició similar a la que hauríem expressat mitjançant un dels enunciats següents:

(7a) Aquest llibre és difícil de llegir

(7b) Aquest llibre és difícil de trobar

(7c) Aquest llibre és difícil d'enquadernar

El minimisme, però, no nega que una emissió de (7) puga comunicar proposicions com les que transmetrien $(7 \mathrm{a}-\mathrm{c})$. On hi ha, doncs, la discrepància, allò que separa una postura de l'altra? Vet ací el punt principal on minimisme i 
contextualisme es troben en desacord: l'existència del que Emma Borg (2004) anomena proposicions minimes. Un minimista sostindria que el contingut explícit, literal, d'allò emès per (7) és la proposició que hom pot obtindre mitjançant el procés de saturació: que $a$ és difícil, on $a$ és un llibre. Un contextualista, en canvi, consideraria que allò explícitament asseverat no es correspon amb aquesta proposició mínima, sinó amb un dels continguts que podem obtindre mitjançant procediments opcionals d'enriquiment pragmàtic: que $a$ és difícil de llegir, de trobar, d'enquadernar, etc. Per als contextualistes, una noció com la de proposició mínima expressada per (7) no té sentit en si mateixa, car no juga cap mena de rol en la comunicació, i només és intel.ligible com a noció derivada, dependent de la de contingut comunicat, el qual es correspondria amb (7a-c): les proposicions mínimes, si existeixen, no tenen cap rellevància psicològica. Els minimistes, en canvi, defensarien que (7a-c) no tenen res a vore amb el contingut explícit de l'emissió, sinó que es transmeten només a nivell implícit.

La discrepància és, doncs, sobre si el contingut explícit d'una emissió de (7) es correspon amb una proposició mínima (el resultat de la saturació) o més aviat amb un contingut pragmàticament enriquit. Per als contextualistes, els mecanismes pragmàtics no només expliquen com es determinen les implicatures, sinó que juguen un rol semàntic molt important, consistent a enriquir contextualment el contingut literal d'una emissió fins assolir-ne un contingut explícit més precís. Una de les teories contextualistes més importants, la teoria de la rellevància (Sperber i Wilson i986; Carston 2002), anomena "explicatura" a aquest contingut explícit que ha estat enriquit de manera opcional sense cap mena de mediació del significat lingüístic; (7a-c) en serien alguns exemples ${ }^{8}$. Si allò explícitament asseverat per un enunciat es correspon amb l'explicatura o amb alguna noció similar, no hi ha divisió de treball entre la semàntica i la pragmàtica: allà on els griceans estrictes sostindrien que aquella es fa càrrec del contingut explícit d'una emissió i aquesta altra

${ }^{8} \mathrm{Hi}$ ha minimistes, però, que han proposat nocions similars. El cas més conegut és el de la noció d" implicitura" de Kent Bach (I994; 200 I; vegeu CARSTON 2002, 170-83 per a una comparació entre totes dues nocions), qui defensa que hi ha enunciats sense díctics que nogensmenys expressen continguts semànticament incomplets:

(a) Josep està preparat

Aquest enunciat pot voler dir que Josep està preparat per fer l'examen, per ser ascendit, per eixir a fer una volta, per anar al llit, etc. Al parer de Bach, és necessari de completar aquest contingut si hom vol obtindre quelcom que es puga avaluar com a vertader o fals, però el fet que aquest enunciat no puga expressar per si mateix cap proposició no el converteix en sensible al context: sempre expressa el mateix. És arran d'açò que hi ha discrepància entre Bach mateix i altres autors (fonamentalment CAPPELEN i LePORE 2005; 2006, manuscrit; vegeu les rèpliques de BACH 2007, manuscrit-a i manuscrit-b) sobre si la proposta compta com a minimista o com a contextualista moderada. 
d'allò transmés implícitament, els contextualistes considerarien que hi ha una intromissió de la pragmàtica en els processos semàntics, ço és, en la determinació d'allò asseverat'. És per això que sovint també se’ls anomena "post-griceans" (JASZCZOLT 2007).

Una bona manera d'il.lustrar aquesta discrepància és fer servir la distinció entre la mentida i el mer engany ${ }^{10}$. Habitualment se sol admetre que per tal de mentir cal dir quelcom de fals; si hom enganya un altre mitjançant una emissió vertadera, no està de fet mentint. Vegem-ne un exemple: demà de matí tinc una reunió programada, i un amic em convida a anar al cinema a vore una pel-lícula que projecten demà de vesprada. A mi no m’abellix anar-hi, de manera que responc així:

(8) Demà tinc una reunió

Com que la reunió està programada per a demà de matí, no és cert que no puga anar al cinema a causa de la reunió; així doncs, la meua emissió ha servit per enganyar l'oïdor, car li he induït una creença falsa. Nogensmenys, el que he dit és literalment cert: demà tinc una reunió. Com que la mentida requereix que el contingut de la meua emissió siga fals, jo no he mentit, sinó que merament he enganyat. La raó per la qual aquests exemples ens interessen és que el minimisme i les diverses varietats de contextualisme acostumen a fer prediccions distintes sobre els valors de veritat del contingut explícit de les emissions que hi apareixen. Considereu, per exemple, un escenari com aquest: Carmesina diu a Tirant que fique el pollastre al forn per tal que el sopar estiga llest quan ella torne a casa. Tirant se n'oblida i, poc abans d'arribar a casa, Carmesina el telefona per tal de demanar-li si ha fet el que li havia encomanat. Aleshores té lloc la conversa següent:

(9) Carmesina: "Has ficat el pollastre al forn, tal com t'havia dit?"

— Tirant: "Sí, l'hi he ficat"

Intuïtivament, diríem que Tirant ha mentit, és a dir, que allò que ha asseverat és fals. Tanmateix, Tirant podria defensar-se dient que, contràriament al que sembla, el que ha dit és vertader: al llarg de la seua vida, ell ha ficat el pollastre al forn moltes vegades. Les propostes contextualistes provarien d'acomodar les intuïcions del parlants —ço és, la idea que Tirant ha mentitmitjançant un seguit d'estratègies per tal d'enriquir el contingut explícit de l'emissió, de manera que la proposició expressada per Tirant resultaria falsa: que ha ficat el pollastre al forn hui o que l'hi ha ficat després que Carmesina li ho diguera, etc. Els minimistes, en canvi, adoptarien l'estratègia de defensa

\footnotetext{
${ }^{9}$ Molts dels assaigs a Sperber i Wilson (2012) són recomanables com a introducció a aquesta idea.

${ }^{10}$ Agraïsc a Tobies Grimaltos i Sergi Rosell les discussions que hem mantingut sobre els exemples que il-lustren aquesta distinció.
} 
de Tirant: atès que no hi ha res al contingut literal de les seues paraules que explicite que l'ordre ha estat duta a terme en el moment requerit per Carmesina, la seua emissió no compta com a mentida ${ }^{11}$, tot i que potser haja aconseguit enganyar Carmesina mitjançant informació transmesa a nivell implícit. En termes generals, els jutges contextualistes condemnarien Bill Clinton per perjuri, mentre que els minimistes, malgrat retreure-li la manca de moral que mostra amb la seua emissió, conclourien que és innocent d'aquesta acusació (vegeu-ne la discussió a SAUL 2002; 2013) ${ }^{12}$.

La raó que els minimistes acostumen a adduir per explicar la tendència a classificar l'emissió de Tirant com a falsa és que els parlants sovint estan equivocats pel que fa al valor de veritat de les seues pròpies emissions, i que els arguments dels contextualistes no tenen en compte totes les variables: no aconsegueixen discernir si el que els parlants reporten és un judici envers allò asseverat o envers el contingut implícit (SAUL 2002; BORG 2010). Els parlants sovint fan servir enunciats que, com (4), expressen falsedats si els entenem literalment, i ho fan perquè d'una banda no en tenen accés a les condicions de veritat $i$, d'altra, es troben en una posició que els permet saber que l'oïdor serà capaç d'inferir el contingut desitjat. Els contextualistes poden respondre que aquest argument pressuposa la distinció entre significat oracional i significat del parlant, que és precisament el que ells rebutgen; de fet, el retret més comú dels contextualistes envers els minimistes és que la noció de proposició mínima, entesa com el con-

${ }^{11}$ Açò és discutible, ja que no només depèn de si hom és o no minimista sinó també de la teoria semàntica que defense. Per exemple, molts minimistes dirien que el contingut explícit de (9) sí que inclou una referència al moment present: està marcat mitjançant la morfologia verbal. De fet, el perfet de l'indicatiu sol ser considerat com un díctic en idiomes com el català o l'italià, on hi ha contrasts com els que il-lustren els exemples següents:

(9a) Hui he posat el pollastre al forn

(9b) \#Ahir he posat el pollastre al forn

(9c) Ahir vaig posar el pollastre al forn

(9d) \#Hui vaig posar el pollastre al forn

(9e) Enguany he posat el pollastre al forn

(9f) \#Enguany vaig posar el pollastre al forn

En català, el perfet de l'indicatiu només es pot fer servir en combinació amb díctics que assenyalen el moment present: (9a) i (9e) són gramaticals, però (9b) i (9f) no ho són; aquest contrast també es produiria si el díctic haguera estat "aquesta setmana" o "aquest segle". Els passats simple i perifràstic, al contrari, només es poden fer servir per seleccionar moments passats sense relació amb cap moment present, fet que explica que combinar aquest temps verbal amb díctics com "hui" o enguany" resulte en agramaticalitat. Així doncs, es podria adduir que Tirant, en fer servir el perfet d'indicatiu, ha asseverat explícitament que ha posat el pollastre al forn en algun moment del passat recent —és a dir, que ha mentit-.

${ }^{12}$ Açò no està del tot clar. Al cap i a la fi l'emissió de Clinton va ser "no hi ha cap relació impròpia", el significat literal de la qual sembla ser que no hi ha arreu del món cap mena de relació (sexual o d'altre tipus) illlícita. La majoria dels minimistes comptarien açò com a fals, fet pel qual Saul (2013) se'n distancia. 
tingut que pot recuperar-se a través d'operacions sintàctiques i sense cap mena d'interferència pragmàtica, no té realitat psicològica. S'ha dut a terme recerca empírica sobre si els parlants incorporen o no el contingut implícit a les condicions de veritat de la proposició expressada, i el ben cert és que els resultats no han estat tot concloents: per exemple, els experiments de Bezuidenhout i Cooper Cutting (2002) apunten a que tant la proposició mínima com l'enriquida són construïdes en paral.lel, tal com prediuen els minimistes, malgrat que la darrera és més facilment accessible; en canvi, les troballes de Breheny, Katsos i Williams (2006) són més favorables al contextualisme.

Una conseqüència de la postura contextualista és que hom pot fer servir un enunciat no-díctic, no-el-líptic i no-ambigu per transmetre, a nivell explícit, proposicions molt diferents depenent del context d'emissió. Els exemples clàssics d'aquesta idea ens els proporcionen els experiments mentals proposats pels pioners del contextualisme, com ara Chales Travis (I977) o John Searle (I980A). Travis ens fa imaginar un escenari en què una xiqueta, Pia, té a casa un auró de fulles rogenques $i$, tot pensant que el color natural de les fulles d'un arbre és el verd, decideix pintar-les d'aquest color. Un cop enllestida la tasca, Pia emet:

(10) Les fulles són verdes

L'enunciat (10) és vertader en aquesta situació. Tanmateix, més endavant Pia rep la visita d'un amic botànic que va a la recerca de fulles verdes per tal d'estudiar-les, i Pia emet, una altra vegada, (10); aquest cop Pia ha dit quelcom de fals. Pia ha fet servir el mateix enunciat per dir una cosa vertadera i una de falsa sense que l'estat de les fulles canviara, fet del qual Travis conclou que les condicions de veritat expressades per aquest enunciat són diferents en cada emissió: "verd" destria una propietat distinta en cadascun dels dos escenaris ("verd per fora", "verd natural", etc.). Searle, per la seua banda, proposa un experiment mental similar per argumentar que el verb "tallar" selecciona propietats diferents depenent de l'ocasió. Segons explica, l'acció associada al verb "tallar" és ben diferent quan tallem la brossa i quan tallem un pastís: si hom agafa un ganivet i fa talls verticals en l'herba tal com ho faria amb un pastís, la seua acció pot comptar com a "tallar la gespa" en moltes ocasions, però no si el que ho fa és un jardiner a qui li paguen per tallar-la. Casos com aquests han esdevingut tot un gènere literari ${ }^{13}$, amb exemples com el de François Recanati (200 I) amb l'espasa del lleó

${ }^{13}$ Travis i Searle són particularment prolífics. El primer (1985; I99I) ens narra, entre d'altres, les diverses maneres com una taula pot estar coberta de mantega, les diferents formes en què hom pot ser mariner i els distints casos en què un ànec pot pesar tres quilos; el segon (1978), per la seua banda, ens explica que ordres com la de tancar la porta o la de dur-me una hamburguesa no poden ser satisfetes només atenent al significat de les meues paraules, sinó que cal informació contextual addicional. Es podria argumentar que l'experiment mental de la cambra xinesa (SEARLE I980B) també constitueix un al-legat contra la idea que el significat puga ser tractat mitjançant operacions de caire sintàctic. 
(la que va servir per matar-lo o la que té en propietat?) o el d'Anne Bezuidenhout (2002) i el color de les pomes vermelles ("destriar pomes vermelles" és una acció diferent segons si el que volem és distingir-les de les verdes o destriar les que, a causa d'una malaltia, han esdevingut roges per dins).

La rellevància d'aquesta mena d'escenaris a l'hora de desenvolupar una teoria semàntica ha estat qüestionada (Predelli 2005B), i a més no tothom comparteix les intuïcions d'aquests autors. Tanmateix, aquests casos serveixen per il.lustrar la idea bàsica del contextualisme: de la mateixa manera que un enunciat amb díctics com (1) pot ésser usat per expressar proposicions distintes tot depenent del context d'emissió, un enunciat com (10), sense dependència contextual evident, també es pot fer servir per comunicar continguts amb condicions de veritat molt diferents. Un mot com "verd" depèn del context tant com qualsevol díctic: de la mateixa manera que "jo" pot seleccionar un individu distint depenent de qui l'emeta, "verd" també pot destriar propietats diferents tot depenent del context d'emissió (verd per fora, verd natural, etc.). És així, doncs, com el contextualisme encaixa a l'esquema que hem proposat a dalt: el context d'emissió juga un rol central en determinar la proposició expressada per un enunciat, més enllà de fenòmens com ara la desambiguació, l'el.lipsi, la dixi o l'anàfora. Ja hem assenyalat, però, que el procés mitjançant el qual una paraula com "verd" selecciona propietats diferents depenent del context no és completament anàleg al funcionament dels díctics com "jo"; per començar, la majoria dels contextualistes ho consideren com un procediment opcional. Les discrepàncies entre els diferents autors d'aquest corrent sorgeixen precisament ací: quin és el mecanisme mitjançant el qual es duu a terme aquesta tasca d'assolir una proposició contextualment enriquida.

Hi ha tot un ventall de propostes que podem classificar com a contextualistes per la manera com proposen tractar un determinat tipus d'expressions. El que hem descrit fins ara és el que hom sol anomenar "contextualisme radical": no hi ha res ni a la sintaxi ni al significat de les paraules que obligue a enriquir la proposició expressada, la qual és obtinguda mitjançant alguna mena de procediment psicològic aliè al llenguatge pròpiament dit. Tanmateix, hi ha altres postures que de vegades també són classificades com a contextualistes i que sí que incorporen aquesta dependència contextual a la sintaxi o la semàntica de les expressions; Borg (20I2) i Clapp (20I2) els hi donen el nom de "dicticistes" 14 . Un dicticista es caracteritzaria per, per exemple, proporcionar

${ }^{14}$ Traducció de l'anglés "indexicalist". De vegades hom fa servir en valencià mots com "indexicalitat" o "indexicalisme" per fer referència als fenòmens relacionats amb la dependència contextual, però açò sembla desencertat, en tant que la paraula "indexical", de la qual en serien derivats, no existeix en el nostre idioma. Una traducció més encertada és la que fa servir l'arrel "índex" per crear mots com "indèxic", d’on es podria derivar "indexicitat" i "indexicista". Tanmateix, allò que sembla més adient és fer servir mots que ja existeixen: "dixi”, "díctic” i els derivats que se’n puguen obtindre. 
una entrada lèxica per a "verd" com la de (10a) o per donar a " $a$ és verd" una forma lògica com la de (10b):

(10a) " $a$ és verd" és vertadera en el context $c$ si i sols si hi ha una propietat $P$ tal que $P$ compta com a verd en $c$ i $a$ té la propietat $P$

(10b) $a$ és verd $(P)$

Si el significat dels enunciats amb la forma " $a$ és verd" és modelat mitjançant (10a), la dependència contextual de "verd" ve donada per la semàntica del mot mateix: seleccionarà una propietat $\mathrm{o}$ una altra tot depenent del context. De manera equivalent, hom pot incorporar aquesta idea a la sintaxi, donant a l'enunciat " $a$ és verd" una forma lògica com (10b), on " $P$ " és una variable que agafa una propietat o una altra en cada context. Aquestes dues postures són essencialment idèntiques, i la dificultat rau a convertir-les en una tesi substantiva: explicar com es destria la propietat adient en cada context o com es dóna un valor a la variable. Trobem anàlisis d'aquest estil a Szabó (200 I), Rothschild i Segal (2009), i Kennedy i McNally (20I0). Un altre exemple clàssic de postura dicticista és l'anàlisi oferida per Stanley i Szabó (2000) per als dominis de quantificació:

(4a) Tots els epistemòlegs (d) han pres cafe

Ací " $d$ " és una variable lliure que selecciona un domini de quantificació contextualment destacat: els epistemòlegs de la facultat, del país, del sopar, etc. La raó per la qual Stanley i Szabó consideren que aquesta variable es troba present a la forma lògica de (4) és que aquests enunciats poden aparèixer subordinats a quantificadors, els quals han de lligar alguna variable (per a crítiques, vegeu CAPPELEN i LePORE 2002):

(4b) A tots els sopars de filòsofs on he estat, tots els epistemòlegs han pres cafè

(4c) [ $\forall d$ : $d$ és un sopar de filòsofs on he estat] ([ $\forall x: x$ és epistemòleg $(d)]$ ( $x$ ha pres cafe $)$ )

Aquests autors plantegen que les variables prenen un valor o un altre depenent del context d'emissió, i de resultes d'aquesta anàlisi el contingut dels enunciats com (4a), (10a) o (10b) varia d'un context a un altre tal com varia el contingut dels enunciats amb díctics.

Ara bé, a primera vista sembla que les anàlisis d'aquest estil contradiuen la idea central del contextualisme: en la mesura que en aquestes propostes les paraules o els enunciats contenen elements sintàctics o semàntics que en marquen la dependència contextual, podria semblar que es troben més aviat properes al minimisme, i de fet encaixen bastant bé a les dues definicions d'aquest que hem proporcionat més amunt. El ben cert és que les postures dicticistes són difícils de classificar; Borg mateixa (2010, 38) les considera més properes al tradicionalisme que no pas al contextualisme, i Recanati (2004) es reserva l'etiqueta "contextualisme" per a les teories que admeten dependència contextual no marcada 
per la semàntica ni la sintaxi, de manera que per comptar com a contextualista no n’hi hauria prou amb analitzar " $a$ és verd" com a (10a) o (10b). Tanmateix, els defensors de les postures dicticistes han estat classificats com a "contextualistes moderats" (CAPPELEN i LePORE 2005) o "contextualistes de corrent majoritari” (Stojanovic 2008). La raó per classificar-los així és que aquestes propostes tracten com a díctics expressions que no ho són de manera òbvia: paraules com "jo", "ací" o "aquest" pertanyen a un grup d'expressions on els mots "verd", "ploure" o "creure" no semblen estar-hi inclosos, i de fet, com ara explicarem, aquelles mostren un comportament molt distint al d'aquestes altres pel que fa a fenòmens com ara anàfora, el-lipsi o discurs indirecte. Així doncs, una proposta també pot comptar com a contextualista si proposa que el llenguatge conté "índexs ocults" o "díctics sorpresa" (CAPPELEN i Lepore 2005), que són postulats en base a la interpretació semàntica que hom vol assolir però sovint sense oferir cap mena de justificació gramatical per a aquest tractament.

Les propostes dicticistes sovint són criticades precisament per equiparar expressions de tota mena amb els díctics. Els contextualistes radicals admeten que expressions com "verd" o "ploure" poden agafar propietats diferents depenent del context, però troben equivocat diagnosticar aquesta mena de dependència contextual com a dixi - si ho fóra, resoldre aquesta dependència contextual seria una tasca obligatòria-. Els minimistes, per la seua banda, senzillament rebutgen que el contingut d'aquests enunciats depenga del context. Les raons esgrimides per aquests darrers autors, però fetes servir també per aquells, és que els díctics presenten unes propietats molt particulars quan interaccionen amb fenòmens com ara el discurs indirecte, l'anàfora, la cancel-labilitat o l'el-lipsi, els quals han estat considerats com a tests per saber si una expressió és dependent del context (CAPpelen i Lepore 2005, cap. 7). Considereu el contrast que es produeix quan traslladem les paraules destacades en negreta, "verdes" i "et", al discurs indirecte:

(11a) Pia adreçant-se a sa mare: "Les fulles són verdes"

(11b) Pia adreçant-se al seu amic botànic: "He dit a ma mare que les fulles són verdes"

(12a) Pia adreçant-se a sa mare: " $\boldsymbol{E} \boldsymbol{t}$ trobe a faltar"

(12b) Pia adreçant-se al seu amic botànic: "He dit a ma mare que $\boldsymbol{e} t$ trobe a faltar"

Tot i que el discurs indirecte no sempre és una bona guia, el contrast entre (11a-b) i (12a-b) mostra que un díctic com "tu" (o el seu derivat "et") no funciona de la mateixa manera que "verd". En traslladar un enunciat sense díctics a un context lingüístic de discurs indirecte, hom pot fer servir exactament les mateixes paraules que hauria utilitzat en discurs directe: la frase subordinada en (11b) és la mateixa que Pia emet en (11a), fet pel qual a (11b) Pia reporta correctament el que ella mateixa havia asseverat a (11a). Açò, però, no és possible en el cas dels 
enunciats amb díctics: si hom agafa les paraules exactes que Pia ha emès en (12a) i les posa sota l'abast d'un verb d'actitud proposicional, com ocorre en (12b), no reporta correctament el que Pia ha dit. La proposició que Pia ha expressat en (12a) és que troba sa mare a faltar, però açò no es correspon amb el contingut que s'atribueix a si mateixa en (12b), on el que assevera és que ha dit a sa mare que troba a faltar el seu amic botànic. Açò és així perquè "tu" agafa un referent distint depenent de a qui ens estiguem adreçant. Per tal de reportar correctament el contingut de Pia a (12a), cal que substituïm "et" per un mot diferent:

(12c) Pia adreçant-se al seu amic botànic: "He dit a ma mare que $\boldsymbol{l} \boldsymbol{a}$ trobe a faltar"

Els minimistes addueixen aquesta asimetria com a mostra que el contingut dels mots no-díctics no depèn del context d'emissió: la raó per la qual hem de canviar de paraula quan traslladem (12a) al discurs indirecte és que "et" agafa un referent distint depenent de a qui ens estiguem adreçant, i el mateix passa amb paraules com "açò", "ara" o "acî", que sovint cal substituir per "allò", "adés" o "allă". Un díctic com "tu" agafa un referent distint en cada context; si "verd" depenguera del context de manera anàloga, allò esperable seria que l'emissió de Pia en (11b) mostrara el mateix contrast, és a dir, que "verd" en aquest context destriara una propietat distinta a la que seleccionava en (11a), i que, en conseqüència, l'emissió de Pia fóra falsa de la mateixa manera que ho és (12b). Aquest no és el cas: independentment de si la conversa és sobre botànica o sobre cromatisme, hom pot emetre "Pia ha dit que les fulles són verdes" en tots els contexts per reportar el contingut de l'emissió original de Pia. En general, els díctics presenten un comportament molt diferent del de la resta d'expressions; vegem-ne un altre exemple:

(13) Pia: "Les fulles són verdes"

- Jaume: "Les fulles no són verdes"

(14) Pia: "Mon pare és a casa"

- Jaume: "Mon pare no és a casa"

En la conversa que té lloc en (13), Jaume contradiu Pia, però en (14) no es produeix cap mena de desacord ni de contradicció entre tots dos. Açò mostra que "verd" i "jo" — o els seus derivats "verdes" i "mon" — tenen un funcionament molt diferent: per tal de negar un enunciat sense díctics només cal afegir "no", tal com Jaume fa a (13), però açò no sempre és possible si hi ha díctics involucrats: a (14), Jaume no contradiu Pia. Aquests exemples mostren que és possible capgirar els experiments mentals de Travis i Searle per defensar exactament el contrari; al cap i a la fi, si jo faig talls verticals en un pastís i després isc al jardí i hi passe la màquina de tallar la gespa, (15) és vertadera:

(15) He tallat tant el pastís com la gespa

Quina propietat destria el mot "tallar" en aquesta emissió? Ha de ser una propietat que tant l'acció de tallar la gespa com el pastís tinguen en comú; si 
Searle tinguera raó quan diu que aquest verb selecciona propietats diferents depenent del context, no hi hauria cap mena de context on (15) fóra vertadera. Altres fenòmens lingüístics com ara l'anàfora, l'el-lipsi, la copredicació i la cancellabilitat també semblen jugar en contra de tractar paraules com "difícil" com a dependents del context. Si "difícil” poguera destriar una propietat diferent en cada context, emissions com les següents no semblarien possibles:

(16) Aquest llibre és difícil, però trobar feina digna ho és més

(17) Aquest llibre és difícil, i els exàmens finals també

(18) Tant la marató com el llibre són difícils

(19) Aquest llibre és difícil, però és facil de trobar

L'enunciat (16) conté un pronom anafòric, "ho", i per tal de resoldre aquesta anàfora cal atribuir al llibre i a trobar feina la mateixa propietat: ser difícils. Açò no seria possible si la propietat que prediquem del llibre és la de ser "difícil de llegir"; amb l'el-lipsi de (17) podem dur a terme un raonament anàleg. L'exemple (18), anàleg a (15), atribueix a la marató i al llibre la mateixa propietat, fet que no encaixa bé amb la idea que "difícil" agafe una propietat o una altra segons el context ${ }^{15}$. La cancel-labilitat també és una dada important: (19) no és contradictòria en cap context, però hauria de ser-ho si en alguns d'ells "difícil" destriara la propietat "difícil de trobar". Aquesta asimetria entre díctics i no-díctics reflecteix la que hi havia al si de les teories davidsonianes respecte a la impossibilitat de donar el significat d'un enunciat amb díctics mitjançant la seua traducció homònima al metallenguatge.

Val a dir, però, que hi ha casos més favorables per als dicticistes. En la teoria estàndard (СhOMSKy 1986; i995; Heim i Kratzer I998 per a l'estàndard en semàntica) hom sol assumir que alguns enunciats contenen elements sintàctics que no són reflectits a nivell fonètic i que, a més, es comporten com si foren pronoms. Aquest és, per exemple, el cas de les traces de moviment sintàctic o els sintagmes $\mathrm{PRO}^{16}$, els quals li semblen molt a la idea d'índexs ocults.

${ }^{15}$ Vegeu també els casos de copredicació a Pustejovsky (1995) i Chomsky (2000).

16 "PRO" (pronunciat "pro gran") no és més que el subjecte dels verbs en infinitiu o gerundi: "El ratolí ${ }_{1}$ vol $\mathrm{PRO}_{1}$ menjar formatge". Han d'estar coindexats amb el seu antecedent anaforic perquè altrament no és possible d'assolir la interpretació desitjada: que el ratolí $x$ vol que $x$ menge formatge. Els idiomes com el valencià o el castellà, amb tendència a elidir el subjecte de molts enunciats, contenen un altre pronom fonèticament nul: "pro" ("pro xicotet"), que fa de subjecte en

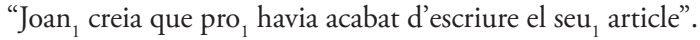

Pel que fa a les traces, són senzillament el resultat del moviment sintàctic. Per exemple, una qüestió com "què has fet?" conté un element desplaçat, l'objecte directe, que no ocupa la seua posició sintàctica habitual ("has fet què"). Hom acostuma a dir que els elements moguts deixen traces de moviment: "què has fet $\mathrm{t}_{1}$ ", on la $t$ marca la posició inicial de l'objecte directe. Aquests elements són fonèticament nuls, però tenen efectes sobre la interpretació de l'enunciat: per exemple, l'enunciat anglès "who do you want to shot?" és ambigu entre dues interpretacions ("a qui vols disparar?" i "qui vols que dispare?"), però "who do you wanna shot?" no ho és (només pot voler dir "a qui vols disparar?"), fet que s'explica perquè "wanna" pot abreujar "want to" però no "want $t$ to". 
D'altra banda, hi ha paraules que hom no classificaria immediatament com a díctics però que passen els mateixos tests: aquest és el cas, per exemple, dels anomenats "verbs díctics de moció" (BARLEW 2017), que inclouen paraules com "anar" i "vindre" o els mots castellans "traer" i "llevar". Aquests són bons candidats, doncs, per ser considerats com a "díctics sorpresa”. D’altra banda, també hi ha predicats les propietats inferencials dels quals semblen indicar que hi ha quelcom més a la forma lògica dels enunciats que els contenen: arran de l'enunciat "aquest gos és un dòberman i és teu" puc inferir "aquest gos és el teu dòberman", però a partir d'"aquell gos és pare i és teu" no és possible d'inferir "aquell gos és el teu pare" (PIETROsKi 2008). Finalment, la morfologia verbal es comporta de manera anàloga als pronoms personals en aquesta mena de tests (Partee i974; Kratzer 1998), fet pel qual hom sovint classifica com a díctics el temps, mode, aspecte i veu verbals.

Els contextualistes radicals, per la seua banda, poden eludir aquesta mena de crítiques dient que aquests fenòmens de caire lingüístic no invaliden la seua tesi, la qual al cap i a la fi consisteix a dir que el context intervé encara que no hi haja res al llenguatge que en faça obligatòria la intervenció: no és que la dependència contextual de (16-19) siga equivalent a la dixi, sinó que allò que aquests enunciats expressen, si és que expressen res per si mateixos, no només pot ser completat mitjançant un procediment com la saturació, sinó que a més pot ser alterat i retorçat a voluntat fins assolir la interpretació adient. Si açò és així, però, no està gaire clar per què les teories contextualistes han de resultar d'interès per al lingüista, que al capdavall el que busca no és una teoria general de la comunicació sinó més aviat una teoria sistemàtica sobre el funcionament llenguatge natural, ço és, dels mecanismes que explicarien, entre d'altres, les asimetries que hem assenyalat. Una crítica comuna dels tradicionalistes envers els contextualistes és, precisament, la d'atribuir a la semàntica el rol d'explicar qüestions que es troben més enllà del seu abast, com ara assumptes relacionats amb la comunicació (Borg 2004; Predelli 2005B).

\section{El TERCER EN DisCòrdia: EL RELATIVISME}

El minimisme sovint fa prediccions que no s'ajusten als judicis dels parlants, i explica aquesta discrepància fent al-lusió a la distinció griceana entre asseverar i implicar. Els contextualistes miren de fer justícia a les intuïcions dels parlants, però ho fan postulant una dependència contextual que o bé no casa amb l'evidència lingüística disponible (en el cas dels dicticistes) o que no resulta d'interès per a l'estudi del llenguatge pròpiament dit sinó que té més a vore amb una teoria general de la comunicació (contextualistes radicals). El 
relativisme, com hem dit més amunt, pot ser vist com una mena de via intermèdia entre tots dos: accepta els arguments dels contextualistes i prova d'oferir una manera sistemàtica de predir les intuïcions dels parlants, però alhora mira de preservar una noció de contingut que no entre en conflicte amb l'evidència lingüística. L'estratègia per aconseguir-ho consisteix a donar més importància al context d'avaluació, normalment afegint-hi més paràmetres a banda d'un món possible — tot i que, com vorem, amb açò encara no n'hi ha prou per comptar com a relativista-.

Una bona manera d'il.lustrar els principis bàsics d'aquesta postura consisteix a discutir una de les seues motivacions: el desacord sense culpa (KöLBEL 2004; LASERSOHN 2005; STOJANOviC 2007; SChaffer 2008). Quan hom està en desacord amb algú altre, la disputa acostuma a poder ser resolta, senzillament, mirant com són les coses en realitat: si vostè opina que el nombre d'arbres de l'avinguda Blasco Ibáńez és parell i jo, per contra, trobe que ha de ser senar, tot el que ens cal és baixar al carrer i comptar-los. Tanmateix, hi ha un tipus de desacord que sol ser expressat mitjançant enunciats que no semblen tan facilment verificables, ja que expressen gusts estètics, opinions polítiques o postures morals. Per exemple, jo puc estar en desacord amb (20):

(20) Les pomes fan bon gust

És plausible d'assumir, amb el contextualista, que (20) no expressa cap proposició absoluta amb unes condicions de veritat determinades; al cap i a la fi, no se sap ben quin és el procediment objectiu que caldria dur a terme per esbrinar si és vertadera o falsa. L'estratègia del contextualisme consistiria a dir que (20) expressa un contingut més ric, plausiblement un contingut a les condicions de veritat del qual el parlant o l'oïdor hi puguen tindre accés, és a dir, un contingut com el que normalment expressaríem mitjançant $(20 \mathrm{a})^{17}$ :

(20a) Al meu parer, les pomes fan bon gust

Açò vol dir que quan hom emet un enunciat sobre gusts estètics està en realitat parlant sobre els seus propis gusts —o potser sobre els de la seua comunitat o cultura- L La raó per la qual els relativistes troben problemàtica aquesta proposta és que faria impossible que els participants de la conversa estigueren en desacord entre ells, per la senzilla raó que cadascú estaria parlant d'una cosa distinta. Imaginem la següent conversa:

(20b) Hèlena: "Les pomes fan bon gust"

- Paris: "No, no en fan"

Aquesta conversa involucra el que pareix un cas legítim de desacord: a Hèlena les pomes li semblen gustoses, però Paris en contradiu l'afirmació per-

${ }^{17}$ Per descomptat, no tots els contextualistes dirien açò, ni tampoc acceptarien que qualsevol emissió d'aquest enunciat expressa aquesta proposició. Açò és més aviat una caricatura del contextualisme que he fet servir per motius expositius. 
què a ell no li ho semblen. D'entrada tots dos tenen raó i no hi ha manera de resoldre la disputa. D'acord amb el contextualista, però, l'emissió d'Hèlena en aquesta conversa comunica un contingut enriquit: que les pomes, al parer d'Hèlena, fan bon gust. Per descomptat, Paris no està en posició de negar aquest contingut: qui millor que Hèlena mateixa per saber què és el que a Hèlena li agrada? Paris, de fet, no estaria negant l'afirmació d'Hèlena, sinó que en realitat només parlaria sobre si mateix, de manera que la seua emissió tindria un contingut com "al parer de Paris les pomes fan bon gust". En conseqüència, Hèlena i Paris no es troben en desacord, sinó que més aviat estan mantenint el que podríem anomenar un "diàleg de sords": estan parlant de coses distintes. Açò és perquè els enunciats com (20), per al contextualisme, expressen coses diferents per a cada parlant; un cas anàleg serien, novament, els enunciats amb díctics:

(21) Ramon: "(Jo) sóc filòsof"

— Ausiàs: "No és cert, (jo) no sóc filòsof"

L'intercanvi que té lloc a (21) no sembla gaire encertat: Ausiàs no aconsegueix negar el que Ramon ha dit, i de fet ni tan sols està parlant sobre el mateix tema. Sembla, doncs, que hi ha una asimetria entre aquest intercanvi i l'altre, perfectament legítim, que té lloc en (20b). La idea que un enunciat com (20) puga expressar proposicions diferents depenent del parlant, de la mateixa manera com "jo" agafa individus distints en cada emissió, té com a resultat que cadascun dels participants en la conversa està parlant sobre el seu propi gust estètic, de la mateixa manera com cada participant de la conversa en (21) parla sobre la seua pròpia professió; aquesta manca d'un tema comú de conversa converteix els desacords en diàlegs de sords.

Cal, doncs, trobar una manera d'aconseguir que enunciats com (20) expressen el mateix contingut per a tots els participants de la conversa, però que alhora permeta explicar per què tant Hèlena com Paris puguen tindre raó en (20b). La solució típica del relativisme consisteix a dir que el context en què estem avaluant l'enunciat no consta només d'un món possible, sinó també d'alguna mena d'estàndard estètic: un individu, una cultura o una època determinats; podem anomenar aquest paràmetre "jutge". Així doncs, els enunciats estètics no són vertaders només en relació amb com siguen les coses (és a dir, en relació amb un món possible) sinó també amb el gust estètic d'un determinat jutge. A (20b), Hèlena avalua el contingut de (20) en el món real i d'acord amb el seu propi gust, obtenint com a resultat la veritat (és cert que al món real, d'acord amb Hèlena, les pomes fan bon gust), mentre que Paris avalua el mateix enunciat al mateix món però d'acord amb un jutge diferent, ell mateix, i de resultes d'açò obté la falsedat. Totes dues emissions, però, tenen el mateix contingut (que les pomes fan bon gust), i el fet que s'obtinguen resultats distints es deu a que són avaluades en paràmetres diferents. 
Aquesta estratègia no només és aplicable a enunciats amb un component subjectiu, sinó també a molts altres casos. Per exemple, un relativista diria que (4) expressa sempre el mateix contingut, però que aquest contingut no és una proposició absoluta que és vertadera o falsa només en relació amb com siga el món, sinó que només pot prendre un valor veritat un cop hem determinat un domini de quantificació adient: serà vertadera si l'avaluem en el món $w$ i el domini que consta dels comensals del sopar, però falsa si l'avaluem en el mateix món però un domini de quantificació diferent — diguem-ne, el domini consistent en el personal investigador de la Facultat de Filosofia de la Universitat de València- Així doncs, els continguts dels enunciats sense díctics no varien d'una emissió a l'altra, però la seua veritat és relativa a un seguit de paràmetres més complex que el que els minimistes acostumen a postular. Una cosa semblant es pot dir de (22):

(22) Plou

Novament, és difícil defensar que la veritat de (22) només és relativa a un món possible: dins d'un mateix món pot haver-hi pluja a Londres i bon oratge a València. En conseqüència, el relativista dirà que (22) és vertader no només en relació amb un món possible sinó també amb un lloc d'avaluació. Aquesta estratègia presenta un avantatge sobre l'opció contextualista (cf. Perry I998), que diria que el contingut de (22) variarà segons el context d'emissió, de manera que depenent de si l'emetem a Lisboa o a París expressarà la proposició que plou a Lisboa o que plou a Paris. Si no es fa cap mena d'ajustament teòric addicional, l'anàlisi contextualista impossibilita distingir (22) de (22a):

(22a) Ací plou

El relativisme pot explicar facilment el contrast entre (22) i (22a): qualsevol emissió de (22) feta a Tòquio expressa, senzillament, la proposició que plou, i aquesta proposició, al seu torn, pot ser vertadera a Moscou i falsa a Santiago de Xile. Tanmateix, (22a) conté un díctic el valor semàntic del qual depèn del lloc d'emissió, de manera que si l'emetem a Tòquio expressarem un contingut ben diferent: que està plovent a Tòquio. Per descomptat, la veritat d'aquesta darrera proposició és independent del lloc d'avaluació: no té gaire sentit dir que la proposició que a Tòquio plou és vertadera a Madrid però no a Los Angeles.

El contextualisme es caracteritzava per postular una alta variabilitat en els continguts que hom pot asseverar mitjançant un sol enunciat, però aquests continguts, un cop determinats, eren vertaders o falsos de manera absoluta. El relativisme fa el moviment contrari: en comptes de postular una alta variabilitat en les possibilitat d'asseveració de continguts, la postula en les condicions de veritat dels mateixos. És així com els relativistes aconsegueixen mantindre una noció de contingut que no varia d'una emissió a una altra i, alhora, fan 
les prediccions que els contextualistes volien assolir: per exemple, que (4) és vertadera en la situació que hem descrit. Així, els relativistes també marquen distància amb el minimisme pel que fa a les dades que una teoria semàntica ha d'explicar: els minimistes haurien dit que (4) és falsa però que es pot fer servir per transmetre, a nivell implícit, quelcom de vertader, mentre que els relativistes fan costat al contextualisme pel que fa a les dades dient que (4) és vertadera.

Un altre punt on els relativistes semblen discrepar dels minimistes és en la noció de contingut: aquests continguts que els relativistes postulen no es corresponen amb la noció tradicional de proposició, que sol correspondre's amb un terme tècnic per designar proposicions metafísiques — conjunts de mons possibles o, alternativament, funcions de mons possibles a valors de veritatPodem anomenar-los, doncs, "proposicions relativitzades". Ara bé, hi ha cap diferència real entre una postura i l'altra? Al capdavall, el minimisme és motivat per dades lingüístiques més que per qüestions com ara la informació comunicada o el contingut mental dels parlants; no és estrany, doncs, que molts dels seus defensors contemporanis hagen provat a deslliurar-se de nocions filosòficament carregades com la de proposició metafísica i hagen adoptat maneres distintes, més relaxades, de concebre el contingut, les quals s'assemblen molt al que esperaríem d'una proposició relativitzada.

La proposta de Predelli (2005A; 2005B), per exemple, és qualificada per ell mateix com a tradicionalista, però sovint se l'emmarca com a relativista $\left(\right.$ MacFARLANE 2007) ${ }^{18}$, en tant que relega la dependència contextual a la postsemàntica. Predelli troba que les crítiques envers les teories tradicionals sovint es deuen a una manera específica de concebre l'aparell teòric que es fa servir en semàntica: nocions com ara "món possible", "contingut" o fins i tot "context" tenen una càrrega filosòfica que ha dut molts autors a atribuir a aquesta disciplina objectius que cauen fora del seu abast. És per això que proposa que els paràmetres d'avaluació no s'entenguen com a mons possibles sinó més aviat com a descripcions més detallades, semblants a les situacions de Barwise i Perry (1983). Aquestes tenen l'avantatge de no estar filosòficament carregades, i són tan útils com els mons possibles a l'hora de tractar assumptes que sí que cauen sota l'abast de la semàntica, com ara l'analiticitat, l'anàfora o la conseqüència lògica. Altres defensors paradigmàtics del minimisme també rebutgen que la semàntica haja de tractar amb qüestions metafísiques o amb nocions com la de contingut mental (Borg 2004; CaPpelen i Lepore 2005). Si açò és així, sembla que no hi ha cap necessitat de donar als mons possibles cap mena d'interpretació filosòfica ni de concebre'ls com a "possibilitats màximes" ni res de

${ }^{18}$ McFarlane (2007) proposa inicialment el nom "contextualisme no-díctic" per a la proposta de Predelli i la seua pròpia. L'etiqueta "relativisme" ha estat més endavant aplicada a aquestes teories. 
semblant; açò vol dir que se'ls pot entendre d'una manera molt similar a com el relativista concep els contexts d'avaluació: el conjunt de paràmetres necessaris per avaluar la veritat d'una emissió.

Així doncs, els minimistes poden relaxar la seua postura fins trobar-se en posició de fer les mateixes prediccions que les teories relativistes i contextualistes, però d'entrada sembla que aquesta versió aigualida del minimisme col-lapsa amb el relativisme. Hi ha, tanmateix, una diferència fonamental entre aquesta i aquella: la noció de veritat. El fet de relativitzar els valors semàntics dels enunciats a dos contexts distints fa possible de definir la noció de veritat de diverses maneres: pot ser una propietat dels enunciats i ser relativa al context d'emissió i d'avaluació, pot ser una propietat dels continguts i ser relativa als contexts d'avaluació, o pot ser una propietat de les emissions i no ser relativa a cap paràmetre (vegeu MACFARLANe 2003 B i STOJANOviC 2008). Els relativistes sovint adopten la primera d'aquestes, ço és, la noció triàdica de veritat:

VERITAT-3: Un enunciat $p$ és vertader únicament en relació amb un context d'emissió $e$ i un context d'avaluació $a$

Adés hem esmentat, però, que els contexts d'emissió i d'avaluació són constructes teòrics que consten de diversos paràmetres seleccionats en base als fenòmens que vullguem modelar. Açò vol dir que molts d'aquests paràmetres poden coincidir: ja hem vist que per tal d'avaluar (22) i (22a) ens cal afegir un paràmetre de lloc tant al context d'emissió com al d'avaluació. Aquesta manera de concebre els contexts permet definir, per a cada context d'emissió $e$, el que podem anomenar el "context d'avaluació destacat per $e$ " o la "circumstància destacada per $e$ ": el context d'avaluació que s'obté copiant els paràmetres que trobem en $e$. Considereu el següent exemple: imaginem que a la nostra teoria els contexts d'emissió són modelats com una quàdrupla que consta d'un parlant, un món possible, un temps i un lloc, mentre que els d'avaluació són concebuts com un parell consistent en un món i un temps. En aquest cas, podem agafar un context d'emissió com <Carnap, $w_{1}, 1947$, Los Angeles> i definir-ne el context d'avaluació destacat com $<w_{1}, 1947>$. En termes generals, per a cada context d'emissió $e$ és possible de definir-ne aquesta circumstància d'avaluació privilegiada que podem simbolitzar com $a_{\mathrm{e}}$. El fet de poder definir aquesta noció és interessant perquè ens permet de reduir la noció triàdica de veritat a una de diàdica, on tot el que ens cal per obtindre veritat o falsedat és tindre un enunciat en un context:

VERITAT-2: Un enunciat $p$ és vertader-2 en un context d'emissió $e$ si és vertader- 3 en $e$ i en el context d'avaluació destacat $a_{e}$, on tots els paràmetres d' $a$ s'obtenen arran dels que hi ha a $e$.

Aquesta noció de veritat és, al parer de Kaplan (1977), la que importa per a qüestions lògiques: al seu sistema LD, la validesa és definida com a 
VERITAT-2 en tots els contexts (i tots els models). La idea que cada context d'emissió en privilegia un d'avaluació és la principal diferència entre el minimisme i el relativisme: per al minimista, quan hom emet un enunciat en un determinat context expressa un contingut al qual ja se li pot assignar veritat o falsedat (tot i que podria haver estat fals en altres circumstàncies), mentre que el relativista, que no admet els contexts d'avaluació destacats, troba que encara no és possible d'assignar veritat o falsedat a aquest contingut, car encara resta trobar un context adient per avaluar-l'hi. És per aquest motiu pel que adés hem esmentat que per tal de comptar com a relativista en relació amb un tipus d'expressions no n'hi ha prou amb afegir a la circumstància d'avaluació un paràmetre del qual aquesta expressió depenga, car un minimista o un contextualista també poden fer-ho. El que cal per tal de comptar com a relativista en relació amb un tipus d'expressió és que el valor semàntic d'aquesta depenga d'un paràmetre del context d'avaluació per al qual el d'emissió no en determine cap valor destacat.

Aquesta idea no només té efectes sobre qüestions com la conseqüència lògica o la validesa ${ }^{19}$, sinó que també serveix per explicar la dinàmica conversacional. Considerem un problema clàssic que el relativisme ha revifat recentment: els futurs contingents (MACFARLANE 2003A). Intuïtivament sembla que el contingut expressat per (23) no és encara ni vertader ni fals:

(23) Demà hi haurà una batalla naval

Per tal d'obtindre el contingut de (23) cal fixar el valor del díctic "demà", $i$ açò es duu a terme inserint la sendemà del dia d'emissió dins la proposició expressada: si el paràmetre de temps del context d'emissió és el vint d'octubre, (23) expressa la proposició que el vint-i-u d'octubre tindrà lloc una batalla naval. Un cop determinat aquest contingut, hom pot demanar-se si (23) és vertadera o falsa. En aquest cas, però, la idea kaplaniana que la veritat és una propietat dels enunciats en un context d'emissió sembla problemàtica: (23), emesa el vint d'octubre, serà vertadera-2 si i sols si la proposició que el vint-i-u d'octubre hi haurà una batalla naval és vertadera el vint d'octubre. D'entrada, açò contradiu les intuïcions que hem esmentat adés: el vint d'octubre aquesta proposició encara no és ni vertadera ni falsa. En canvi, aquesta intuïció és facil d'acomodar dins la concepció relativista de la veritat: el context d'emissió no determina el context en què hem d'avaluar (23), sinó que encara és possible de seleccionar-ne un de més adient — presumiblement, un de posterior al dia vint-i-u- Vet ací, doncs, el tret central de les propostes relativistes: emetre un enunciat en un context determina un contingut, però amb açò encara no

${ }^{19} \mathrm{Al}$ sistema de Kaplan, per exemple, "Plou" és conseqüència lògica de "Plou ara"; aquesta inferència, però, no és vàlida en els marcs relativistes. Vegeu MacFarlane (2003B), Predelli i Stojanovic (2008) i Predelli (2012). 
estem en posició per poder avaluar aquest contingut com a vertader o fals, perquè encara resta seleccionar els paràmetres adients per dur a terme aquesta avaluació.

Aquesta idea, però, es pot implementar de diverses maneres. Fins ara hem descrit una postura relativista genèrica, però hi ha altres maneres d'explicar per què la veritat d'una emissió pot ser relativa a paràmetres diferents per a cada parlant. Hom pot, per exemple, mantindre una noció de veritat similar a la kaplaniana, on el context d'emissió sí que determina la circumstància que cal fer servir per avaluar l'emissió, però dir que cadascun dels participants en la conversa disposa d'un context d'emissió diferent. Una altra opció és la de relativitzar el contingut d'una emissió en comptes de la seua veritat: hom pot adoptar una noció tradicional de proposició com una funció de mons possibles (i res més) a valors de veritat, però dir que quina siga aquesta funció dependrà d'un seguit de fets del món, i que aquests fets són relatius — aquesta postura seria un relativisme metafísic- . Finalment, també és possible explicar aquesta relativització si considerem que l'extensió de les expressions no depèn dels dos contexts que hem estat tractant fins ara sinó també d'un tercer: podem dir que cada context determina la seua pròpia circumstància destacada, però que a banda del context d'emissió i la seua circumstància encara hi ha un context d'avaluació que és diferent d'aquesta última. En la majoria dels casos aquestes diferències són una mera qüestió de formalisme i no suposen cap diferència quan es considera les teories extensionalment, però sí que poden reflectir una manera particular de concebre filosòficament les nocions que es fan servir.

Algunes de les dades que motiven el relativisme han estat posades en qüestió. En el cas dels futurs contingents, per exemple, és possible argumentar que no és cert que per tal d'avaluar la proposició expressada calga esperar a un moment determinat: qualsevol teoria externista sobre el significat lingüístic pot apel-lar a la metasemàntica i dir que els fets futurs determinen el contingut de les emissions presents (BaLl, pendent de publicació). Així, una emissió de (23) feta el sis d'octubre expressarà que el dia set d'octubre hi haurà una batalla naval, i aquesta proposició pot ser vertadera ja el mateix dia sis, tot i que encara no en tinguem accés a les condicions de veritat. Una cosa semblant podem dir dels enunciats amb adverbis modals com "potser" (MacFarlane 2008; SCHAFFER 2008):

(24) Joanot: "Potser Ausiàs siga a la facultat"

- Isabel: "No, t'equivoques: m’ha trucat adés per dir-me que hui estava malalt i que es quedaria a casa"

La manera habitual de tractar el significat de "potser" és la contextualista: "potser Ausiàs siga a la facultat" és vertadera si i sols si la informació de què $A$ disposa és compatible amb que Ausiàs siga a la facultat, on $A$ és el parlant. Els 
relativistes (notablement MACFARLANe 2008) addueixen que aquesta manera de tractar "potser" faria impossible la conversa (24): com podria Isabel negar el que Joanot ha asseverat? Al capdavall, el que aquesta emissió expressa és cert: que Ausiàs haja anat a la facultat no és incompatible amb l'evidència de què Joanot disposa. Addicionalment, Joanot mateix pot, més endavant, penedir-se de la seua pròpia afirmació i negar-la (ço és, pot continuar la conversa dient "Tens raó, aleshores no hi pot ser"), cosa que amb l'anàlisi contextualista no sembla possible. La solució relativista és la d'incloure al context d'avaluació un paràmetre d'informació disponible: l'emissió de Joanot a (24) serà vertadera en ser avaluada d'acord amb la informació de què Joanot disposa en eixe mateix moment, però falsa si se l'avalua d'acord amb un paràmetre d'informació distint. És per això que el que Joanot diu és vertader quan ho avalua en el seu propi context, però al mateix temps Isabel es troba en posició de negar-ho, i potser Joanot mateix també ho podrà negar quan adquirisca més informació (ço és, quan el seu context d'avaluació canvie).

El contextualista, però, pot donar una resposta molt similar a la que havíem considerat per a l'enunciat de les batalles navals: des d'una perspectiva externista, el contingut d'una emissió pot estar determinat per fets posteriors a la mateixa, com ara el fet que més endavant hom estiga disposat a penedir-se'n (BALl, pendent de publicació). Per exemple, és ben natural que la conversa en (24) continue amb Joanot dient "Tens raó, aleshores segur que no hi és", i que Hèlena continue (21b) amb "Tens raó, no ho són”. Aquestes disposicions dels parlants poden comptar com a part de la metasemàntica, ço és, com a negociacions metalingüístiques, i en conseqüència poden determinar que les emissions originals de Joanot i Hèlena siguen en realitat falses en comptes de vertaderes. Açò soscava la motivació inicial del relativisme: a (21b) i a (24) no hi ha realment desacord sense culpa, sinó un simple desacord on un parlant contradiu l'altre. D'altra banda, tant el contextualista com el minimista tenen oberta la possibilitat d'explicar (24) per una via alternativa: hom pot dir que el que Isabel està negant en (24) no és pas el contingut explícit de l'emissió d'Ausiàs, sinó més aviat alguna mena de contingut implícit ${ }^{20}$.

Hi ha molts altres tipus d'expressions per als quals s'han desenvolupat propostes relativistes, $\mathrm{i}$ fins $\mathrm{i}$ tot hi han autors que han proposat de relegar a la post-semàntica el tractament de les expressions díctiques: Santorio (20 I 2)

${ }^{20}$ Considereu el següent intercanvi:

— Joanot: "Saps si Ausiàs ha vingut?"

- Isabel: "No"

Hom pot demanar-se si en aquest intercanvi el que Isabel nega és el contingut semàntic de l'emissió de Joanot o alguna mena de contingut implícit; en el primer cas, Isabel ha dit que no sap si Ausiàs ha vingut, $\mathrm{i}$ en el segon el que ha asseverat és que Ausiàs no ha vingut. El que ocorre a (24) pot ser una cosa semblant. 
planteja que els pronoms són variables i que la funció d'assignació que els dóna un valor cal localitzar-la al context d'avaluació, i Nowak (pendent de publicació) fa el moviment anàleg a l'hora de tractar els demostratius; en la seua proposta el context d'emissió ni tan sols determina quina és aquesta funció. Aquestes i altres qüestions han contribuït a revifar una versió del vell relativisme, ara convertit en un debat de caire lingüístic.

\section{QUÈ ÉS EL CONTINGUT?}

El minimisme, el contextualisme i el relativisme són tres les tres principals postures dins del debat sobre com establir la divisió entre semàntica $\mathrm{i}$ pragmàtica. El minimisme postula l'existència d'un contingut mínim que podem avaluar com a vertader o fals i que pot ser recuperat mitjançant operacions formals sense més influència del context que la requerida per l'enunciat mateix; el contextualisme, en les seues diverses vessants, troba que aquestes proposicions mínimes no van enlloc i proposa tot un seguit d'estratègies per enriquir-ne el contingut contextualment; el relativisme, per la seua banda, accepta una noció semblant a la de contingut mínim expressat per totes les emissions d'un enunciat, però considera que per tal d'avaluar aquest contingut com a vertader $o$ fals encara cal trobar un paràmetre adient.

Tota aquesta discussió gira al voltant de dues nocions clau, "contingut" i "context", que no són gaire clares. Els contexts sovint són entesos com a constructes teòrics mitjançant els quals es modelen diversos fenòmens, però la relació que mantenen amb la realitat no és immediata: no està gens clar que aquestes col-leccions de paràmetres que els teòrics fan servir representen realment contexts d'emissió, en el sentit de l'escenari on efectivament té lloc un acte físic consistent a emetre un enunciat. Per exemple, en alguns casos sembla més apropiat concebre aquests constructes com una representació dels paràmetres que són fixats per les intencions del parlant (Predelli 1998; 20 I 2) o per l'escenari físic on l'oïdor rep l'emissió (Sidelle i99I). En qualsevol cas, no sembla que la manera com s'hagen d'obtindre aquests paràmetres siga part de la semàntica com a tal, la qual més aviat s'ocupa de què ocorre un cop han estat fixats. D'altra banda, sembla difícil modelar els contexts del contextualisme com a simples col.leccions de paràmetres; Recanati (200I), per exemple, troba que aquesta mena de constructes poden ser, com a molt, una part de la noció més rica i general de context pragmàtic.

La noció de contingut és encara més fosca, i jo diria que més rellevant per a la discussió. La caracterització que n’hem oferit a la primera secció el presenta com la informació transmesa per un enunciat, allò asseverat o allò dit. 
Sovint se l'identifica també amb les creences comunicades o el contingut dels estats mentals. Tanmateix, hi ha diversos problemes amb aquestes maneres de concebre'l.

En primer lloc, no està gens clar per què la informació transmesa hauria de ser identificada amb un conjunt de mons possibles. Aquesta noció clàssica de proposició és l'habitual en epistemologia o filosofia de la ment, però d'entrada no hi ha cap raó per donar-li cap paper preponderant en semàntica o pragmàtica: els mons possibles poden resultar útils a l'hora de modelar el significat dels morfemes de mode o dels verbs i adverbis modals, però les raons per les quals els necessitem són les mateixes que podríem adduir per als instants de temps, que resulten imprescindibles per tractar els díctics temporals i els morfemes de temps, o per als individus, que són indispensables per al tractament dels pronoms i dels morfemes personals. Hom pot, doncs, demanar-se per què allò asseverat hauria de correspondre's amb conjunts de mons possibles i no amb conjunts de parells que consten d'un món i un temps, o amb conjunts de triplets conformats per un món, un temps i un individu ${ }^{21}$. En aquest sentit, els relativistes semblen haver encertat bastant.

Una segona raó és que ni tan sols està gens clar que la semàntica haja d'ocupar-se d'una noció com la de contingut, entenent aquest com a informació comunicada (Lewis I980; NinAN 20IO; RABERN 20 I 2; YALCIN 20I4; RABERN i BALL 20I9). Si entre els objectius de la semàntica hi ha el d'esdevindre una part més de l'estudi del llenguatge juntament amb la sintaxi, la fonètica o la morfologia, aleshores els models que fa servir han de ser entesos com a models de la capacitat humana per al llenguatge (Yalcin 20I8), i més específicament d'una part del coneixement del llenguatge, en el sentit de Chomsky (1986). La possessió d'aquesta capacitat no té per què correspondre's amb l'habilitat de ser un bon comunicador, entesa com la capacitat de transmetre continguts de manera eficient. Més rellevantment, per tal de modelar la manera com els parlants són capaços de generar i copsar enunciats que mai abans havien escoltat és plausible d'assumir que la semàntica del llenguatge natural ha de ser composicional, però la noció de contingut emprada per la majoria de teories no sembla ser-ho ${ }^{22}$. Si la composicionalitat és una noció que ha de guiar

${ }^{21}$ Neale (2006) argumenta que no hi ha cap motiu per afavorir uns paràmetres sobre els altres. Vegeu Schaffer (2012) per a una discussió de les analogies entre els dominis modal i temporal en les proposicions.

${ }^{22}$ Per exemple, per tal de tractar composicionalment la quantificació en el llenguatge natural hom necessita assignar a les expressions valors semàntics que varien arreu de les funcions d'assignació (RABERN 20I3). La majoria de les teories tracten el contingut com funcions de mons possibles o de mons possibles i instants de temps, i no sembla gaire atractiu d'afegir les funcions d'assignació entre aquests paràmetres: quin trellat té que la proposició expressada siga vertadera depenent del món possible, instant de temps i funció d’assignació en què se l'avalue? 
la recerca en la semàntica i els continguts no són composicionals, quina podria ser la raó per tractar-los-hi?

Ja hem esmentat que els minimistes contemporanis, contràriament als seus predecessors, també rebutgen la idea que la semàntica haja d'ocupar-se d'assumptes que tenen a vore amb la comunicació, tot i que ho fan per motius distints. Així doncs, és ben possible que el contextualisme tinga raó en refusar d'identificar la noció minimista de contingut, que es correspon amb les proposicions mínimes, amb la informació asseverada per una emissió. Tanmateix, tampoc no està clar que la noció de contingut plantejada pels contextualistes, que es correspon amb una proposició contextualment enriquida, siga una noció requerida per la semàntica, sinó que més aviat sembla pròpia d'una teoria general de la comunicació. Ara bé, si açò és així sembla que no tenim cap mena de raó per incorporar a la semàntica una noció com la de proposició mínima: si no es correspon amb la informació transmesa i tampoc no juga cap paper en determinar composicionalment el valor semàntic de les expressions, quina necessitat hi ha de postular-la?

$\mathrm{Al}$ meu parer sí que hi ha raons importants per mantindre a la semàntica una noció com aquesta, tot i que jo proposaria d'incorporar-la-hi d'una manera una mica diferent. Vet ací el motiu: tal com hem explicat, la noció de contingut a l'estil del minimisme o del relativisme és necessària per tal de modelar correctament fenòmens que sí que cauen dins l'abast de la semàntica, com ara l'el-lipsi, l'anàfora, l'analiticitat o la cancel-labilitat, i potser també la conseqüència lògica. Certament, resultaria del tot sorprenent que la mateixa noció que serveix per explicar aquests fenòmens coincidira amb la que una teoria de la comunicació faria servir per modelar la transmissió d'informació, o amb la noció amb què epistemòlegs i filòsofs de la ment modelen les creences i els estats mentals. Açò, però, no vol dir que els contextualistes radicals tinguen raó quan asseveren que el contingut contextualment no enriquit no té cap mena de rellevància psicològica: el fet que els parlants no hi tinguen accés de manera conscient no vol dir que la capacitat de processar proposicions mínimes no jugue cap rol dins la capacitat del llenguatge; establint una analogia, els parlants no tenen accés conscient a les formes fonètiques dels enunciats, i tanmateix ningú no diria que aquestes no representen i expliquen trets psicològics.

El contingut, doncs, pot servir com a noció teòrica per modelar fenòmens que tenen a vore amb la facultat humana per al llenguatge, la qual forma part de la psicologia humana. Cal concebre'l, però, com un terme teòric propi de la semàntica la relació del qual amb nocions similars a altres disciplines està lluny de resultar òbvia, i açò comporta que els parlants no tenen per què tindre-hi accés conscient, ja que el que estem modelant és un parlant idealitzat. Així doncs, el que ens cal és, al meu parer, un concepte de contingut despullat 
de connotacions metafísiques, formalment tractable i amb una variació contextual mínima, com el del relativisme estàndard o el de la versió més laxa del minimisme. El fet mateix d'utilitzar el mot "contingut" pot haver esdevingut una font de confusió pel que fa com concebre'l, de la mateixa manera que pot haver ocorregut $\mathrm{amb}$ altres mots amb contraparts a altres àmbits del coneixement, com ara "món possible", "context" o, fins i tot, "veritat". La càrrega filosòfica d'aquestes nocions pot haver estat un llast per al debat: en la mesura que sovint contextualistes, relativistes i minimistes les conceben de manera distinta, és possible que fins ara no hagen estat realment en desacord, sinó més aviat mantenint un diàleg de sords. 


\section{BIBLIOGRAFIA}

BACH, K. I994, "Conversational impliciture”, Mind \& Language 9: 124-62.

BaCH, K. 200 I, "You Don't Say?”, Synthese 128: 15-44.

BACH, K. 2007, "The Excluded Middle: Minimal Semantics without Minimal Propositions," Philosophy and Phenomenological Research 73 (2): 435-42.

BACH, K. (manuscrit-a), "Minimalism for Dummies: a Reply to Cappelen and

Lepore", disponible a http://userwww.sfsu.edu/kbach/replytoC\&L.pdf.

BaCH, K. (manuscrit-b), "From the Strange to the Bizarre: Another Reply to Cappelen and Lepore", disponible a http://userwww.sfsu.edu/kbach/reply2toC\&L. pdf.

Ball, D. 20I7, "What Are We Doing when We Theorize about Context Sensitivity?", The Routledge Handbook of Epistemic Contextualism, J. J. IcHIKAWA (ed.), Abingdon: Routledge, 105-18.

Ball, D., "Relativism, Metasemantics, and the Future", pendent de publicació a Inquiry.

Barlew, J. 2017, The Semantics and Pragmatics of Perspectival Expressions in English and Bulu: The Case of Deictic Motion Verbs, tesi doctoral, The Ohio State University.

Barwise, J. i Perry, J. I983, Situations and attitudes, Cambridge (Massachusetts): MIT Press.

Bezuidenhout, A. 2002, "Truth-Conditional Pragmatics", Philosophical Perspectives 16: 105-34.

Bezuidenhout, A. i Cooper Cutting, J. 2002. "Literal meaning, minimal propositions, and pragmatic processing", Journal of Pragmatics 34: 433-56.

Borg, E. 2004, Minimal Semantics, Òxford: Oxford University Press.

Borg, E. 20io, "Semantics and the Place of Psychological Evidence", SAwyer, S. (ed.), New Waves in Philosophy of Language, Basingstoke: Palgrave Macmillan, $24-40$.

Borg, E. 20 12, Pursuing Meaning, Òxford: Oxford University Press.

Breheny, R.; Katsos, N. i Williams, J. 2006, “Are Generalised Scalar Implicatures Generated by Default? An On-Line Investigation into the Role of Context in Generating Pragmatic Inferences", Cognition 100: 434-63.

Cappelen, H. i Lepore, E. 2002, "Indexicality, binding, anaphora and a priori truth", Analysis 62 (4): 271-81.

Cappelen, H. i Lepore, E. 2005, Insensitive Semantics: a defense of semantic minimalism and speech act pluralism, Òxford: Blackwell.

Cappelen, H. i Lepore, E. 2006, "Reply to Bach", Philosophy and Phenomenological Research 73: 469-73. 
Cappelen, H. i Lepore, E. (manuscrit), "Kent Bach on Minimalism for Dummies", disponible a http://hermancappelen.net/docs/KBM.pdf.

Carnap, R. 1947, Meaning and Necessity, Chicago: University of Chicago Press.

Carston, R. 2002, Thoughts and Utterances, Òxford: Blackwell.

Сномsку, N. 1986, Knowledge of Language: its Nature, Origin and Use, Nova York: Praeger Publishers.

Chomsky, N. 1995, El Programa Minimista: els Escrits de Chomsky, Barcelona: Ariel, I998.

Chomsky, N. 2000, New Horizons in the Study of Language and Mind, Nova York: Cambridge University Press.

Church, A. i95 I, "A formulation of the logic of sense and denotation", P. Henle (ed.), Structure, Method and Meaning, Nova York: The Liberal Arts Press, 3-24.

Clapp, L. 20I2, "Three challenges for indexicalism", Mind \& Language 27 (4): 435-65.

Frege, G. I 892, "Über Sinn und Bedeutung", Zeitschrift für Philosophie und philosophische Kritik 100: 25-50

Glanzberg, M. 2014, "On Explanation and Partiality in Semantic Theory", A.

Burgess i B. Sherman (eds.), Metasemantics; New Essays on the Foundations of Meaning, Nova York: Oxford University Press, 259-92.

Grice, H. P. I961, “The Causal Theory of Perception”, Proceedings of the Aristotelian Society, Supplementary Volume 35: 121-52.

Grice, H. P. i975, "Logic and conversation”, P. Cole i J. Morgan (ed.), Syntax and Semantics, 3: Speech Acts, Nova York: Academic Press, 41-58.

Heim, I. i Kratzer, A. I998, Semantics in Generative Grammar, Oxxford: Blackwell.

ICHIKaWA, J. J. (ed.) 20I7, The Routledge Handbook of Epistemic Contextualism, Abingdon: Routledge.

Jaszczolt, K. M. 2007, “On Being Post-Gricean”, R. A. Nilsen; N. A. A. Amfo, i K. Borthen (ed.), Interpreting Utterances: Pragmatics and Its Interfaces, Oslo: Novus, 21-38.

Kaplan, D. I977, "Demonstratives", Almog, J. et al. (ed.), Themes from Kaplan, Òxford: Oxford University Press, I989, 481-564.

Kennedy, C. i Mcnally, L. 2oio, "Color, context, and compositionality", Synthese 174: 79-98.

KRIPKE, S. I959, "A Completeness Theorem in Modal Logic", Journal of Symbolic Logic, 24 (1): 1-14.

Kripke, S. I963A, "Semantical Analysis of Modal Logic I: Normal Modal Propositional Calculi", Zeitschrift für Mathematische Logik und Grundlagen der Mathematik 9: 67-96.

Kripke, S. I963в, "Semantical Considerations on Modal Logic", Acta Philosophica Fennica 16: 83-94. 
Kripke, S. I972, Naming and Necessity, Òxford: Basil Blackwell, I980.

Kratzer, A. I998, "More structural analogies between tenses and pronouns", D. Strolovitch i A. Lawson, Proceedings of SALT VIII, 92-110.

Lasersohn, P. 2005, "Context Dependence, Disagreement, and Predicates of Personal Taste", Linguistics and Philosophy 28 (6): 643-86.

Lewis, D. I980, "Index, context and content", S. Kanger i S. Öhman (ed.), Philosophy and Grammar, Reidel Publishing, 79-100.

MacFarlane, J. 2003A, "Future Contingents and Relative Truth", Philosophical Quarterly 53: 321-36.

MacFarlane, J. 2003в, "Three Grades of Truth Relativity", manuscrit disponible a https://johnmacfarlane.net/3grades.pdf.

MacFarlane, J. 2005, "Making Sense of Relative Truth", Proceedings of the Aristotelian Society 105: 321-39.

MacFarlane, J. 2007, "Semantic Minimalism and Nonindexical Contextualism", G. Preyer i G. Peter (ed.), Context-Sensitivity and Semantic Minimalism: New Essays on Semantics and Pragmatics, Nova York: Oxford University Press, 240-50.

MacFarlane, J. 2008, "Epistemic Modals are Assessment-Sensitive", B. Weatherson i A. Egan (ed.), Epistemic Modality, Òxford: Oxford University Press, 144-78.

Marcus, R. 1946, "A Functional Calculus of First Order Based on Strict Implication", The Journal of Symbolic Logic 11: 1-16.

Montague, R. i970, "Universal Grammar", Theoria 36: 373-98.

Neale, S. 2006, "Ontological Symmetry in Language: a Brief Manifesto", Mind \& Language 21 (4): 504-39.

Ninan, D. 2010, "Semantics and the Objects of Assertion", Linguistics and Philosophy 33 (5), 355-80.

NowaK, E., "No context, no content, no problem", pendent de publicació a Mind \& Language.

Partee, B. 1973, "Some structural analogies between tenses and pronouns in English", The Journal of Philosophy LXX (18): 601-9.

Perry, J. I996, "Thought without Representation", Proceedings of the Aristotelian Society Supplementary Volume 60: 263-83.

Predelli, S. 2005A, Contexts. Meaning, Truth, and the Use of Language. Òxford: Oxford University Press.

Predelli, S. 2005B, "Painted Leaves, Context and Semantic Analysis", Linguistics and Philosophy 28, 351-74.

Predelli, S. I998, "I am not here now”, Analysis 58 (2): 107-15.

Predelli, S. 20 1 2, "Indexicality, Intensionality, and Relativist Post-Semantics", Synthese 184 (2): 121-36. 
Predelli, S. i Stojanovic, I. 2008, "Relativism and the Logic of Indexicals", M. Kölbel i M. Garcia-Carpintero (ed.), Relative Truth, Òxford: Oxford University Press, 63-79.

Pustejovsky, J. 1995, The generative lexicon, Cambridge: MIT Press.

RABERN, B. 201 2, "Against the identification of assertoric content with compositional value", Synthese 189: 75-96.

Rabern, B. 2013, "Monsters in Kaplan's LD”, Philosophical Studies 164: 393404.

Rabern, B. i Ball, D. 2019, "Monsters and the Theoretical Role of Context", Philosophy and Phenomenological Research 98 (2): 392-416.

Recanati, F. 200I, "What is said", Synthese 198: 75-91.

Recanati, F. 2004, Literal Meaning, Cambridge: Cambridge University Press.

Richard, M. I993, "Attitudes in Context", Linguistics and Philosophy 16 (2): $123-48$.

Rothschild, D. i Segal, G. 2009, "Indexical predicates”, Mind \& Language 24: 467-93.

Santorio, P. 2012, "Reference and monstrosity", Philosophical Review 121 (3): $359-406$

SAul, J. 2002, "What is Said and Psychological Reality: Grice's Project and Relevance Theorists' Criticisms", Linguistics and Philosophy 24, 347-72.

SAul, J. 2013, Lying, Misleading and the Role of What is Said, Oxford: Oxford University Press.

Schaffer, J. 2008, "Perspective in Taste Predicates and Epistemic Modals", B. Weatherson i A. Egan (ed.), Epistemic Modality, Òxford: Oxford University Press, 179-226.

Schaffer, J. 20 r 2, “Necessitarian Propositions”, Synthese 189 (1): 119-62.

Searle, J. 1978, "Literal Meaning”, Erkenntnis 13: 207-24.

Searle, J. i980a, "The Background of Meaning”, J. Searle; F. Kiefer i M. Bierwisch (ed.), Speech-act theory and pragmatics, Dordrecht: Reidel, 221-32.

Searle, J. I980в, "Minds, Brains and Programs", Behavioral and Brain Sciences 3 (3): 417-57.

Sidelle, A. I99I, “The answering machine paradox", Canadian Journal of Philosophy 21: 525-39.

SoAmes, S. 2002, Beyond Rigidity, Òxford: Oxford University Press.

Sperber, D. i Wilson, D. I986, Relevance: Communication and Cognition, Cambridge (Massachusetts): Harvard University Press.

Sperber, D. i Wilson, D. 20 I 2, Meaning and Relevance, Nova York: Cambridge University Press.

Stanley, J. i Szabó, Z. 200o, "On quantifier domain restriction”, Mind and Language 15, 219-61. 
Stojanovic, I. 2007, "Talking about taste: disagreement, implicit arguments, and relative truth", Linguistics and Philosophy 30 (2): 691-706.

Stojanovic, I. 2008, "The Scope and the Subtleties of the Contextualism/Literalism/Relativism Debate", Language and Linguistics Compass 2 (6): 1171-88.

Szabó, Z. 200 I, "Adjectives in context", I. Kenesei i R. M. Harnish (ed.), Perspectives on Semantics Pragmatics and Discourse: A Festschrift for Ferenc Kiefer, Amsterdam: John Benjamins, 119-46.

Travis, C. 1977, "Pragmatics", B. Hale i C. Wright (ed.), A Companion to the Philosophy of Language, Òxford: Blackwell, 187-229.

Travis, C. 1985 , "On what is strictly speaking true", Canadian Journal of Philosophy 15: 187-229.

Travis, C. I991, "Annals of analysis: Studies in the Way of Words, by H. P. Grice", Mind 100: 237-64.

Westerstånl, D. 20 I2, "Compositionality in Kaplan-style semantics", The $O x$ ford handbook of compositionality, W. Hinzen et al. (ed.), Òxford: Oxford University Press, 192-219.

Williams, M. I99I, Unnatural Doubts: Epistemological Realism and the Basis of Skepticism, Cambridge (Massachusetts): Blackwell.

Williamson, T. 2005, "Contextualism, subject-sensitive invariantism and knowledge of knowledge”, Philosophical Quaterly 55: 213-35.

YalCIN, S. 2014, "Semantics and metasemantics in the context of generative grammar", A. Burgess i B. Sherman (ed.), Metasemantics; New Essays on the Foundations of Meaning, Nova York: Oxford University Press, 17-54.

Yalcin, S. 2018, "Semantics as a Model-Based Science", B. Rabern i D. Ball (ed.), The Science of Meaning. Essays on the Metatheory of Natural Language Semantics, Nova York: Oxford University Press, 334-60. 

Notes de discussió i ressenyes 

QUADERNS DE FILOSOFIA VOL. VI NÚM. 2 (2019): I 3 I-4I

eISSN: 234I-3042 DOI: I0.7203/QFIA. 6.2.I6056

Óscar Cubo

Universitat de València

\section{Los límites exteriores del capitalismo en la "crítica de la economía política" de Marx. Sobre la interpretación de César Ruiz Sanjuán de la articulación de historia y sistema en Marx}

The Outer Limits of Capitalism in Marx's "Critique of Political Economy». On César Ruiz Sanjuán's Interpretation of the Articulation of History and System in Marx.

Recibido: / Aceptado:

Resumen: Se ha publicado recientemente en castellano una investigación rigurosa y pionera acerca de la compleja articulación que mantienen la historia y la exposición del sistema capitalista en el proyecto de una "crítica de la economía política" de Marx. Este trabajo pretende exponer y discutir las aportaciones interpretativas abiertas por el libro de César Ruiz Sanjuán: Historia y sistema en Marx. Hacia una teoría crítica del capitalismo, publicado en 2019 en la editorial Siglo XXI España. Al final de nuestra exposición profundizamos en esta articulación entre historia y sistema con vistas a presentar el proyecto político del Marx maduro como un desarrollo consecuente de su "crítica de la economía política".

Abstract: A groundbreaking and rigorous research has recently been published in Spanish on the complex articulation between history and the exposure of capitalist system in Marx's project of a "Critique of Political Economy". This work aims to present and discuss the interpretative contributions opened by César Ruiz Sanjuán's book Historia y sistema en Marx. Hacia una teoría crítica del capitalismo, published in 2019 by Siglo XXI España. At the conclusion of this paper, we delve into this articulation between history and system in order to present 
Marx's mature political project as a consequent development of his "Critique of Political Economy".

Paraules clau: historia, sistema y crítica de la economía política.

Keywords: history, system and critique of political economy.

$\mathrm{T}$ RAS UN ENORME BAgaje EN LA TRADUCCIÓn de la obra de Michael Heinrich al castellano ${ }^{1}$ y en la difusión en el mundo hispanohablante de lo que en Alemania se conoce como la "nueva lectura de Marx", el profesor César Ruiz Sanjuán presenta un detallado trabajo sobre la relación que guardan lo histórico y lo sistemático en la obra de K. Marx. Una de las mayores dificultades a las que se enfrenta Ruiz Sanjuán en su trabajo es el hecho de que el propio Marx en su evolución intelectual "pasa por distintas fases en el proceso de formación de su teoría, lo que exige abordar el conjunto de su obra para comprender cómo se configura dicha articulación en su formulación teórica definitiva” (Ruiz SAnjuán 20 I9, 9). A lo largo de estas fases, Marx mantiene una fructífera discusión con la filosofía especulativa de G. W. F. Hegel que Ruiz Sanjuán reconstruye a lo largo de su libro de una manera detallada y precisa.

El propósito fundamental del libro es, por tanto, reconstruir esta evolución intelectual de Marx, objetivo que se lleva a cabo en dos pasos: el primero, dedicado a la "Génesis de una concepción histórica de la realidad social" (25162) y, el segundo, centrado en "La exposición sistemática como crítica de las categorías" (163-390). En esta última parte del libro es donde se presenta en toda su complejidad la formulación teórica definitiva de Marx acerca del modo como ha de entenderse la relación entre historia y sistema en su proyecto de una crítica de la economía política. La reconstrucción de la evolución teórica de Marx a lo largo de las dos partes del libro es ejemplar por varios motivos, el primero de ellos, por el tratamiento de las fuentes (muy complejas en el caso de la obra de Marx) y, en segundo lugar, por las delimitaciones previas que el autor emprende antes de embarcarse en su compleja tarea. Respecto a la primera cuestión, esto es, respecto al tratamiento de las fuentes, el autor hace uso de primera mano del corpus marxiano proponiendo en numerosas ocasiones traducciones propias, y mantiene una traducción consecuente y bien pensada de los conceptos fundamentales que Marx emplea a lo largo de toda su obra. Un lector atento puede entrever el enorme trabajo de traducción que Ruiz San-

${ }^{1}$ Véase: Crítica de la economía política. Una introducción a "El Capital" de Marx (2008) y ¿Cómo leer "El Capital" de Marx? Indicaciones de lectura y comentario del comienzo de "El Capital" (20 I I), ambas obras aparecidas en la editorial Escolar y Mayo. 
juán ha realizado en los últimos ańos y la importancia que ello tiene cuando se trabaja sistemáticamente el corpus marxiano, que aún dista mucho de estar completamente traducido al castellano.

En segundo lugar, y por lo que respecta a las delimitaciones previas que Ruiz Sanjuán presenta en la "Introducción", resulta patente que el autor ha sabido hacer suyos uno de los rasgos distintivos de la "nueva lectura de Marx", que consiste en investigar el corpus marxiano con el esmero y cuidado que merecen los autores clásicos de la historia de la filosofía. Con vistas a ello Ruiz Sanjuán emprende una delimitación interna y una delimitación externa del corpus textual que quiere investigar. La primera de estas delimitaciones conlleva una periodización precisa de la obra de Marx que haga posible "separar los elementos teóricos que no encuentran continuidad en la ulterior elaboración de su teoría de aquellos que permanecen y permiten arrojar luz sobre ella" (9). Mientras que la segunda delimitación, esto es, la delimitación externa implica establecer "una línea de demarcación sistemática entre los textos de Marx y los de Engels, lo cual hace posible analizar la relación existente entre ellos y constatar las posibles diferencias que se puedan presentar, en lugar de presuponer que Marx sostiene determinados planteamientos que no se encuentran explícitamente formulados en ningún lugar de su obra e interpretar esta a partir de dichos planteamientos" (10).

Los frutos interpretativos más prominentes de ambas delimitaciones del corpus marxiano, así como del tratamiento directo de las fuentes marxianas, los encontramos especialmente en la segunda parte del libro, donde Ruiz Sanjuán descifra minuciosamente la compleja articulación de lo histórico y sistemático en el proyecto teórico de la crítica de la economía política. Las cuatro versiones disponibles de El Capital constituyen las fuentes primarias del trabajo de Ruiz Sanjuán, aunque también forman parte consustancial de la presente investigación los Grundrisse y el Urtext, ya que en opinión del autor ambos textos permiten completar ciertos vacíos teóricos que se presentan en El Capital. La importancia de los Grundrisse y el Urtext consiste en que permiten localizar ciertas alteraciones en la concepción metodológica de Marx a lo largo de los años posteriores a la redacción de los manuscritos, a pesar de ser el primer volumen de El Capital el verdadero legado intelectual de Marx. "En cuanto a los libros segundo y tercero de El Capital [...] en la medida en que se trata de textos de Marx no acabados y no preparados para su publicación, son escritos del mismo rango que el resto de los manuscritos de la crítica de la economía política" (175). Por todo ello, Ruiz Sanjuán se distancia por igual "de las interpretaciones que consideran que los textos de los que hay que partir son los manuscritos, y de las interpretaciones que sostienen que se debe tomar en consideración exclusivamente El Capital y hay que desechar los manuscritos, e 
incluso la Contribución" (178). Frente a este uso sesgado del corpus marxiano, Ruiz Sanjuán adopta como texto fundamental el primer volumen de El Capital y recurre a la Contribución y a los diversos manuscritos de Marx "para aclarar o para completar la exposición de El Capital en los puntos en que esta sea menos precisa o esté menos desarrollada" (Ibid.).

Pues bien, de este enorme trabajo con las fuentes y del análisis comparativo de los distintos manuscritos, Ruiz Sanjuán extrae importantes resultados por lo que respecta al proyecto teórico del Marx maduro. El primero de ellos, sería lo que podemos denominar la "tesis de la popularización", según la cual Marx fue popularizando progresivamente su exposición de la crítica de la economía política en sus sucesivas versiones, haciendo que "las articulaciones metodológicas [se fueran] quedando cada vez más ocultas” (17). Esta progresiva simplificación de la exposición tuvo una gran importancia en la recepción de la obra de Marx, tanto en el marxismo oriental como en el marxismo occidental, favoreciendo interpretaciones sesgadas y equívocas de su proyecto científico y político. Según Ruiz Sanjuán, esta popularización tuvo lugar por "los sucesivos intentos por parte de Marx de paliar el elevado nivel de abstracción de su exposición del valor y de hacerla más accesible" (184). La consecuencia más negativa de esta popularización fue el progresivo ocultamiento del método que está a la base de la crítica de la economía política y la disolución de los tránsitos dialécticos que enhebran los distintos momentos de la crítica en su conjunto.

Otro resultado que conviene destacar es la "tesis de la centralidad de la teoría del valor", que según Ruiz Sanjuán constituye el concepto clave para exponer y al mismo tiempo criticar el proceso social específico del sistema capitalista. Esta especificidad de la teoría del valor impide igualmente su empleo como una teoría suprahistórica para explicar todas las relaciones de intercambio en general, incluidas las relaciones económicas de las formaciones sociales precapitalistas. Hacer hincapié en la historicidad del proceso de producción específico del sistema capitalista implica igualmente mostrar "el carácter históricamente determinado de las relaciones sociales del modo de producción capitalista" (20).

Posiblemente el resultado más importante de la obra de Ruiz Sanjuán es sacar a la luz el método que hay a la base de la crítica de la economía política. Según el autor, en los Grundrisse encontramos la primera concepción metodológica de Marx como base de su exposición sistemática de las categorías fundamentales de la economía política (167). Este primer borrador de la crítica de la economía política fue elaborado por Marx en 1857, es decir, diez años antes de la publicación de El Capital, y constituye para Ruiz Sanjuán "la base para todas las posteriores versiones de la crítica de la economía política” (171). Un elemento clave de la comprensión de la metodología de Marx es el carácter 
abstracto del punto de partida de la exposición de El Capital. En efecto, "la exposición de El Capital comienza con una construcción conceptual en la cual las relaciones económicas consisten en el intercambio de mercancías y dinero, y el capital no se presenta todavía en ningún momento. Esto no significa que Marx esté analizando sociedades históricas en las que no existe aún el capital, sino que en su exposición de la sociedad capitalista comienza haciendo abstracción del capital. Marx realiza esta abstracción en el primer nivel de su exposición porque con ello se expresa una dimensión constitutiva fundamental de la moderna sociedad capitalista, en la que la esfera de la circulación es lo que se presenta de manera inmediata en la superficie de la sociedad" (223).

A este respecto, en los Grundrisse Marx afirma explícitamente que el proceso de conocimiento de las relaciones sociales capitalistas tiene que comenzar necesariamente con las abstracciones más simples, y a partir de ellas ir generando conceptos progresivamente más concretos con vistas a ir aprehendiendo en el pensamiento lo que aparece inmediatamente como real. Solo si se consuma esta "ascensión" de lo abstracto a lo concreto se comprende el fundamento de lo que aparece inmediatamente (Cf. Grundrisse 1974, 167; 1976, 194). Esta ascensión puede entenderse como una suerte de deducción, ya que "en las formas simples del comienzo están contenidas de manera germinal las formas acabadas, en el sentido de que son momentos abstractos aún no desarrollados teóricamente" (Ruiz SANJuÁn 20i9, 227). Esto es lo que explica para Ruiz Sanjuán que la deducción del concepto de capital tenga lugar a partir del concepto de valor y que una vez deducida lógicamente la categoría del capital, el resto de las categorías se desarrollen a partir de ella, "ya que [el concepto de valor] constituye la categoría central del modo de producción capitalista" (Ibid., 208).

Lo especialmente relevante de estas consideraciones del libro que aquí se presentan es que ellas constituyen las premisas necesarias para comenzar a dar una respuesta a la pregunta acerca de la articulación entre sistema e historia en la crítica de la economía política de Marx. Esta respuesta se despliega en dos pasos. En primer lugar, la entera exposición de la estructura del sistema capitalista avanza deductivamente a partir del concepto de valor hasta alcanzar la categoría del capital en un desarrollo teórico que es independiente del proceso histórico a través del cual ha surgido el capitalismo. Podemos denominar a esta idea la "tesis de la independencia", esto es, de la independencia del despliegue de la exposición sistemática de su génesis histórica. En este sentido, el proceso histórico a través del cual ha surgido el capitalismo queda fuera y es independiente de la exposición sistemática. No obstante, y esto constituye el segundo paso, "la exposición teórica de las relaciones capitalistas constituidas [es] la que da la «clave» para la comprensión del proceso histórico" (Ibid., 217). De 
la exposición sistemática se obtiene, pues, un "principio de orientación" para el estudio de la génesis histórica del capitalismo ya que "el análisis teórico de la estructura acabada indica la dirección en la que hay que investigar los procesos históricos, pero esta investigación histórica, que presupone el desarrollo lógico, tiene a su vez la función de ilustrar la exposición sistemática y, lo que es más importante, de completarla allí donde no es posible la deducción conceptual de los correspondientes fenómenos históricos" (Ibid., 206).

Quisiera mencionar a este respecto cuatro ideas presentes en el texto de Ruiz Sanjuán: la primera, es la relevancia teórica del desarrollo lógico de la exposición del sistema capitalista, puesto que, como hemos visto, el análisis teórico de la estructura acabada indica la dirección en la que hay que investigar los procesos históricos; en segundo lugar, que entre sistema e historia hay a nivel teórico una relación de presuposición: la investigación histórica presupone el desarrollo lógico y sólo entonces obtiene la función de ilustrar la exposición sistemática; en tercer lugar, que la historia completa la explicación de aquello que la exposición sistemática no puede dar cuenta por ella misma y, por último, que el proceso deductivo tiene un "límite insuperable", ya que arriba a ciertos presupuestos históricos de los que no puede dar cuenta.

Esta última cuestión está íntimamente vinculada al procedimiento deductivo que emplea Marx en su exposición del sistema capitalista y que se diferencia del método especulativo hegeliano. La génesis histórica del capitalismo constituye en el proyecto de una crítica de la economía política una suerte de factum del que ha de partir la exposición. "Esto significa que la exposición de Marx, a diferencia de la de Hegel, no cancela sus propios presupuestos, sino que estos determinan, por el contrario, los límites del desarrollo conceptual. Estos supuestos son el producto de un proceso histórico previo, cuyo resultado es la condición objetiva de la exposición del sistema constituido" (Ibid., 242). A pesar de que la comprensión marxiana del método es deudora de la filosofía hegeliana en la medida en que "Marx considera que el método científicamente correcto asciende desde las abstracciones más simples a las determinaciones conceptuales más concretas" (Ibid., 278), Marx no concibe al pensamiento "como un movimiento autosuficiente que no requiera de ningún supuesto exterior a él" (Ibid., 277). Es decir, y esto es muy importante para Ruiz Sanjuán, "la exposición marxiana no suprime en el curso de la misma sus propios presupuestos, como en el caso de la hegeliana, sino que dichos presupuestos permanecen como algo exterior e independiente del proceso lógico" (Ibid., 320), siendo la génesis histórica del capital lo que constituye el propio límite de su análisis sistemático.

Este "límite histórico" se hace patente tras la exposición del sistema, esto es, en los dos últimos apartados del primer volumen de El Capital dedicados a "La llamada acumulación originaria" y "La teoría moderna de la colonización". 
En ellos se ilustra históricamente el surgimiento de la mercancía fuerza de trabajo y del capital dinerario cuya existencia constituye la conditio sine qua non de lo que Marx denomina «relación capitalista». Lo que Marx muestra en estos últimos apartados es que tanto el surgimiento histórico de la mercancía fuerza de trabajo como la acumulación pre-capitalista de dinero son el resultado de procesos históricos que no se pueden deducir de la exposición teórica del propio sistema capitalista. Alcanzar este "límite histórico" tras la exposición del sistema exige, pues, explicar los presupuestos históricos del capitalismo, esto es, "explicar aquello que no resulta accesible a la exposición sistemática de las categorías" (Ibid., 207).

Lo original de la crítica de la economía política de Marx en este punto es que a la necesidad de explicar dichos presupuestos históricos sólo se llega tras la exposición sistemática del modo de producción capitalista. Es decir, "sólo expuesto el sistema capitalista en su configuración esencial, se puede exponer el proceso histórico que ha dado lugar a dicho sistema" (Ibid.). A este respecto, Marx alude a la "circularidad de su exposición" (Cf. Resultate 2009в, 20 y ss; 2000, 109 y ss), pero con ello no se está refiriendo, según Ruiz Sanjuán, "en ningún caso a la circularidad hegeliana, en la que la exposición asume dentro de sí su presupuesto concreto, sino que con ello señala precisamente los límites de [su] exposición" (Ruiz SANJuÁn 20I9, 242); límites que remiten a la constitución histórica de la "relación de capital" que, por cierto, es ella misma "reproducida como resultado del propio proceso de producción" (Ibid., 380) de una manera ampliada.

Estos presupuestos concretos que son analizados al final de los mencionados apartados del primer volumen de El Capital, funcionan desde mi punto de vista como una suerte de "postulados" dentro del desarrollo categorial que presenta Max en El Capital. Ruiz Sanjuán no los interpreta como postulados de la exposición, tampoco lo hace Marx, pero creo que a través de los resultados obtenidos por Ruiz Sanjuán en su trabajo se pueden denominar "postulados" a los presupuestos a los que llega la exposición del sistema capitalista de Marx. Ciertamente, estos presupuestos históricos constituyen el límite exterior de la exposición del sistema, ya que su génesis no se explica ni se puede explicar a través de la exposición del sistema capitalista. Esto conlleva a su vez la apertura de dos ámbitos distintos de investigación: el campo de investigación propio de la crítica de le economía política y el campo de la investigación histórica de los elementos que constituyen los presupuestos fundamentales del sistema de producción capitalista. En este último caso resulta decisivo investigar el surgimiento histórico de la acumulación pre-capitalista de dinero y de los procesos históricos que dieron lugar a la desposesión generalizada de los medios de subsistencia para buena parte de la población, incluyendo en estos últimos, el sur- 
gimiento y establecimiento de las colonias por parte de las potencias coloniales hegemónicas en las distintas fases de la expansión histórica de las relaciones capitalistas de producción.

El otro ámbito de investigación lo constituye la propia crítica de la economía política de Marx: un campo autónomo de investigación y desligado de lo histórico en la medida en que lo que busca presentar El Capital es "la organización interna del modo de producción capitalista, por así decirlo, en su medida ideal" (Kapital 1973, 839; 2009, 1057). Enfatizar la autonomía de ambos campos de investigación es fundamental para disociar la exposición sistemática del sistema capitalista de su génesis histórica, y sobre todo para evitar la interpretación que llevó a Engels a identificar "la deducción conceptual del modo de producción capitalista y la explicación del proceso histórico de formación del mismo" (RUIz SANJUÁn 20 I9, 198). Insistir en dicha autonomía permite poner en tela de juicio esta interpretación de Engels, que en realidad no se corresponde con la comprensión marxiana de la crítica de la economía política ni con la exposición y estructura de El Capital.

Insistimos, a los dos últimos apartados "históricos" del primer volumen de El Capital es preciso arribar, ya que "sólo cuando las categorías que expresan las relaciones del modo de producción capitalista están suficientemente definidas, se puede exponer el proceso histórico a través del cual ha surgido el capitalismo" (Ibid., 198). Este proceso histórico deviene un objeto de estudio fundamental tras la exposición de la estructura social capitalista. Gracias a dicha exposición resulta necesario investigar la génesis histórica de las relaciones capitalistas, la cual a su vez pone de relieve el carácter histórico de dichas relaciones, a pesar de que dicha exposición ya las presupone como plenamente constituidas. Ahora bien, tras la exposición de la estructura social capitalista también se pone de relieve que tanto la existencia de la fuerza de trabajo como la existencia de la posesión inicial de dinero constituyen presupuestos históricos indispensables para el surgimiento de las relaciones de capital. Estos presupuestos tienen que ser postulados por Marx, porque para que sean posibles las relaciones sociales capitalistas ha de haber tenido lugar un proceso histórico de expropiación de los medios de subsistencia de buena parte de la población y ha tenido que acontecer una acumulación pre-capitalista de dinero. Pero, si esto es cierto, resulta inevitable preguntarse si Marx necesita realmente recurrir a la historia para verificar su exposición del sistema capitalista o si puede prescindir de toda corroboración histórica, puesto que ambos fenómenos socio-históricos han tenido que acontecer, ya que de lo contrario no podría explicarse el nacimiento del modo de producción capitalista.

¿Podría influir esta corroboración de los historiadores (que también podría ser una desaprobación a partir de los hechos históricos) en la validez de la 
exposición de las relaciones capitalistas tal y como se presentan en El Capital? Pienso que no, y por este motivo considero oportuno tratar ambos fenómenos históricos (la supuesta expropiación de los trabajadores y la supuesta acumulación pre-capitalista) como dos postulados fundamentales de la crítica de la economía política de Marx. Respecto al primero de estos fenómenos, Marx afirma que la acumulación originaria es indisociable del "proceso histórico de separación de los productores de sus medios de producción" (Kapital I983, 742; 2009, 892), y en Salario, precio y ganancia (I 865) insiste en que "aquello que los economistas denominan acumulación previa u originaria [...] debería de llamarse expropiación originaria. Y veríamos que esta llamada acumulación originaria no es sino una especie de procesos históricos que acabaron destruyendo la unidad originaria que existía entre el hombre trabajador y sus medios de trabajo" (Lohn 1962, 131; i976, 43).

Pienso que la corroboración o desaprobación a partir de los hechos históricos de lo que está aquí diciendo Marx no afecta a la validez de su exposición de las relaciones capitalistas tal y como se presentan en El Capital, porque dichos presupuestos históricos han de ser postulados necesariamente para poder dar cuenta de las relaciones capitalistas plenamente constituidas. En el caso de los trabajadores, por ejemplo, tiene que haberse consumado la separación entre el trabajador y sus medios de subsistencia, porque de lo contrario no se podría encontrar la fuerza de trabajo en el mercado (Cf. Grundrisse i974, 226, 363 y ss; 1976, 260-1, 420 y ss). Los historiadores, en el mejor de los casos, podrán investigar cómo sucedió esta expropiación originaria de los trabajadores, pero no podrán ponerla en duda, ya que se trata con arreglo a lo expuesto en el primer volumen de El Capital de uno de los presupuestos fundamentales sobre el que reposa el sistema de producción capitalista.

En este sentido, Marx insiste también en que el objetivo último que se sigue de la crítica de la economía política es la reinstauración de "la primitiva unidad [de los productores con sus medios de producción] bajo una forma histórica nueva" (Lohn 1962, 131; 1976, 43). De modo que suprimir las relaciones capitalistas equivale a proporcionar de nuevo a los trabajadores sus medios de subsistencia, esto es, a cancelar la mencionada expropiación original (Cf. Kapital I983, 791; 2009, 953). El programa político resultante de la crítica de la economía política resulta, pues, inequívoco: reapropiar a los expropiados suprimiendo la ley de apropiación capitalista. Con ello, dice Marx, "se restaura la propiedad individual, pero sobre el fundamento de la conquista alcanzada por la era capitalista: la cooperación de los trabajadores libres y su propiedad colectiva sobre la tierra y sobre los medios producción producidos por el trabajo mismo" (Ibid.).

En definitiva, el trabajo realizado por Ruiz Sanjuán es una investigación pionera a la hora de dilucidar la relación que mantienen la historia y el sistema 
en la crítica de la economía política de Marx, articulación que sin duda tiene un gran número de aristas. La única cuestión que queda sin tratar explícitamente en su trabajo es lo que yo denominaría el segundo límite exterior del sistema capitalista: el que se vislumbra con su posible supresión. Una de las escasas observaciones que hace Marx al respecto en el primer volumen de $E l C a$ pital es la siguiente: "imaginémonos [...] una asociación de hombres libres que trabajen con medios de producción colectivos y empleen, conscientemente, sus muchas fuerzas de trabajos individuales como una fuerza de trabajo social. [...] [En este caso,] el tiempo de trabajo desempeñaría un doble papel. Su distribución, socialmente planificada, regulará la producción adecuada entre las varias funciones laborales y las diversas necesidades. Por otra parte, el tiempo de trabajo servirá a la vez como medida de la participación individual del productor en el trabajo común, y también, por ende, de la parte individualmente consumible del producto común" (Kapital I983, 92-3; 2009, 96-7). Para mí, resulta de un enorme interés tratar este segundo límite bajo la óptica que nos presenta Ruiz Sanjuán en su libro sobre historia y sistema. Si el primer límite exterior del sistema capitalista apunta a su génesis histórica, el segundo señala hacia su posible trascendencia. El primero de estos límites saca a la luz sus presupuestos históricos, mientras que el segundo nos hace ver que otra sociedad es posible. No obstante, y al igual que el primero, este segundo límite solo se puede obtener tras la exposición del sistema, ya que solo entonces se puede ganar un principio de orientación política con vistas a alterar las relaciones capitalistas de producción. 


\section{REFERENCIAS BIBLIOGRÁFICAS}

Heinrich, M. 2008, Critica de la economía politica. Una introducción a El Capital de Marx, Madrid: Escolar y Mayo.

Heinrich, M. 20 i i, ¿Cómo leer El Capital de Marx? Indicaciones de lectura y comentario del comienzo del Capital, Madrid: Escolar y Mayo.

Marx, K. I962A, Lohn, Preis und Profit, Karl Marx Friedrich Engels Werke (MEW 16), Berlín: Dietz Verlag.

Marx, K. I962B, Kritik des Gothaer Programms, Karl Marx Friedrich Engels Werke (MEW 19), Berlín: Dietz Verlag.

Marx, K 1968, Salario, precio, ganancia, Madrid: Ricardo Aguilera.

Marx, K. I97 I, Critica del Programa de Gotha, Madrid: Ricardo Aguilera.

MarX, K. I974A, Zur Kritik der politischen Ökonomie, Berlín: Dietz Verlag.

MarX, K. I974B, Grundrisse der Kritik der politischen Ókonomie (Rohentwurf) 1857-1858, Berlín: Karl Dietz Verlag.

Marx, K. I976, Elementos fundamentales para la critica de la economía politica, Argentina: Siglo XXI.

Marx, K. I973, Das Kapital. Kritik der politischen Ökonomie, Band III, Karl Marx Friedrich Engels Werke (MEW 25), Berlín: Dietz Verlag.

Marx, K. I983, Das Kapital. Kritik der politischen Ökonomie, Band I, Karl Marx Friedrich Engels Werke (MEW 23), Berlín: Dietz Verlag.

Marx, K I990, Contribución a la critica de la economía política, México: Siglo XXI.

Marx, K. 2000, El Capital. Libro I, Capitulo VI (inédito). Resultados del proceso inmediato de producción, México: Siglo XXI.

Marx, K. 2009A, El Capital, Argentina: Siglo XXI.

Marx, K. 2009B, Resultate des unmittelbaren Produktionsprozesses, Berlín: Karl Dietz Verlag.

Ruiz SANJuÁn, C. 20I4, "La evolución teórica del marxismo: del materialismo histórico a la crítica de la conciencia fetichista", Isegoría. Revista de Filosofía Moral y Politica, 50: 143-65.

Ruiz Sanjuán, C. 2019, Historia y sistema en Marx. Hacia una teoría critica del capitalismo, Madrid: Siglo XXI. 

QUADERNS DE FILOSOFIA VOL. VI NÚM. 2 (20I9): I 43-6

eISSN: 234I-3042 DOI: I O.7203/QFIA. 6.2.I6057

Matt Sleat (ed.) 20 I 8, Politics Recovered: Realist Thought in Theory and Practice, Nueva York: Columbia University Press. ISBN 9780231547550, 408 páginas.

¿Qué supuestos metodológicos deberíamos admitir cuando hacemos filosofía política? ¿Deberíamos asumir que nuestra tarea es clarificar principios morales que posteriormente aplicamos al ámbito político? ¿ $\mathrm{O}$ es más bien lo político un ámbito específico con una normatividad específica? Más aún, ¿debería la filosofía política ser normativa o su empresa más genuina es de carácter descriptivo, genealógico o conceptual? La mayoría de la filosofía política angloamericana durante las últimas cinco décadas, bajo la influencia de la teoría de la justicia John Rawls, se ha dedicado a la tarea normativa, partiendo de principios morales que luego aplica al ámbito político y a menudo sin considerar restricciones de carácter histórico o sociológico. El libro aquí reseñado es una colección de ensayos que defiende y usa un enfoque alternativo: el que se conoce en la filosofía analítica como "realismo político", un enfoque filosófico heterogéneo que ha de ser entendido en parte como reacción contra el moralismo de la tradición rawlsiana y en parte como un proyecto en construcción.

Estrictamente hablando, como nos recuerda el editor en la introducción, el realismo en filosofía política no es algo nuevo. Clásicos de la tradición como Marx, Hegel, Max Weber o Maquiavelo han teorizado sobre política al margen de consideraciones morales. No obstante, la adopción de una perspectiva no moralizante es algo poco común en la tradición analítica. Hubo que esperar a la principal doctrina que inspira estos ensayos, la inacabada filosofía política de Bernard Williams, para que el realismo adquiriera un lugar destacado. La idea inaugural de Williams es que la filosofía política no debería empezar diseñando un modelo moral para aplicarlo luego al ámbito político, antes bien, ha de reconocer la autonomía de lo político. Así pues, la primera cuestión política es cómo conseguir estabilidad, orden y seguridad. No obstante, para que haya politica propiamente y no simplemente guerra o violencia, aquellos sometidos a coerción han de recibir una justificación aceptable del orden al que están sometidos. La existencia de esa justificación es lo que vuelve el orden legítimo. En el contexto moderno, de acuerdo con Williams, tal justificación se otorga si el orden es liberal. Es importante el énfasis en que es en el contexto moderno donde la legitimidad se plasma en el liberalismo, dado que la teoría de Williams intenta evitar considerar todos los órdenes anteriores a la modernidad 
como ilegítimos. Finalmente, Williams pone énfasis en que la legitimidad está sometida al principio de teoría crítica, que enuncia que, para ser legítima, la aceptación de un orden por parte de aquellos que están sometidos a él no puede estar creada por la coerción que se pretende justificar. Dado que la teoría de Williams fue publicada en un ensayo póstumo en 2005 ("Realism and Moralism in Political Theory"), el proyecto realista está en el presente simplemente esbozado. A menudo los autores realistas han puesto más esfuerzo en atacar el moralismo que en usar el realismo para abordar dilemas políticos. No obstante, no sería justo ver en el realismo únicamente una reacción. Autores ampliamente reconocidos en la teoría política actual orbitan el paradigma realista y entre ellos cabe mencionar a James Tully, Bonnie Honig, Chantal Mouffe, Raymond Geuss o Charles W. Mills.

Los ensayos de este libro pueden dividirse en tres grupos: el de quienes intentar corregir o defender la causa realista, el de quienes ponen el realismo contemporáneo a dialogar con otras tradiciones y el de quienes aplican el realismo a casos de investigación concretos. En el primer grupo, destaca el capítulo de Glen Newey. Aplicando la más estricta metodología analítica, Newey intenta refutar una de las defensas más robustas del utopismo en filosofía política: la visión metanormativa de G. A. Cohen. Como es sabido, Cohen argumentó que todos los principios que dependen de un hecho para ser ciertos (fact-sensitive principles), reflejan en última instancia un principio que no depende de ningún hecho (fact-insensitive principles). Para Cohen, la clarificación de estos últimos principios es una empresa potencialmente fructífera para la filosofía política. Newey nos ofrece nueve motivos que vuelven esta tesis problemática, defiende que no hay motivos sólidos para preferir una filosofía política que se mueva en un nivel tan abstracto y concluye delimitando un campo para la filosofía política "libre de suplementos normativos". También es sumamente ilustrativo el ensayo de David Owen, centrado en situar la filosofía política de Bernard Williams dentro de su proyecto filosófico realista. Owen encuentra un continuo entre el compromiso de Williams con una disposición hacia el mundo comprometida con la verdad y su realismo y concluye demandando una teoría realista de la legitimidad que contemple retos transnacionales como la proliferación nuclear o el cambio climático. Paul Sagar nos alerta sobre algunos problemas que puede tener el principio de teoría crítica, dado que a menudo órdenes desiguales que parecen a primera vista claramente ilegítimos son aceptados de buen grado y sin ningún tipo de distorsión cognitiva por quienes están sometidos a ellos. William Galston realiza una excelente defensa del papel de emociones como el orgullo en el análisis del comportamiento político. Por su parte, Charles Larmore, aceptando el marco general de Bernard Williams, defiende que este se equivocó al considerar que la legitimación del orden político no viene dada por 
la moralidad. Todos estos ensayos son magníficos ejercicios de filosofía política analítica y contribuyen a perfilar con nitidez un programa realista. El libro, no obstante, no se queda exclusivamente en un nivel programático.

Varios capítulos del libro están dedicados a casos de estudio y entre estos cabe mencionar el ensayo de Mark Philp sobre corrupción, en el cual se nos alerta de una perspectiva excesivamente centrada en Occidente cuando intentamos definir el fenómeno. Por su parte, Rahul Sagar defiende que, a pesar de las demandas habituales de publicidad e igual acceso a la información en teoría de la democracia, el secretismo es una característica estructural de las democracias contemporáneas. Richard Bellamy analiza las perspectivas neomaquiavélicas como la de Jonathan Powell, que trabajó en la administración de Tony Blair, y defiende que no hay contradicción intrínseca a un liderazgo de inspiración maquiavélica que sea sensible a las demandas populares. Finalmente, entre quienes ponen al realismo a dialogar con otras tradiciones, es reseñable el ensayo de Duncan Bell. Bell parte de una visión realista en relaciones internacionales e intenta medir desde los habituales presupuestos (conflicto, anarquía, interés nacional como primer imperativo, etc.) las posibilidades de implementar las teorías más ambiciosas de justicia global. La conclusión que extrae es que, por más robustas y bienintencionadas que sean estas teorías de la justicia, su implementación conllevaría una "securitización" de la pobreza, esto es, conllevaría entender la pobreza como una amenaza existencial, los cual, a su vez, llevaría a las grandes potencias a solucionar el problema pasando por encima de controles democráticos. Otra conexión disciplinar es la que realiza Elizabeth Frazer, que defiende de manera sólida que teorías feministas de diversa índole han adoptado diversos presupuestos metodológicos realistas. Alison McQueen, por su parte, defiende que los realistas clásicos en relaciones internacionales y los nuevos realistas en filosofía política comparten suficientes rasgos como para ser considerados de la misma familia teórica. Queda, pues, sobradamente demostrado, que hay un respetable linaje realista y que el realismo contemporáneo puede entablar un diálogo fructífero con otras tradiciones.

La colección de ensayos es rica, estimulante y demuestra que hay una alternativa plausible al moralismo en filosofía política. No obstante, refleja un problema corriente con los enfoques realistas. Demasiados ensayos se centran más en criticar el moralismo de raíz rawlsiana que en aplicar el realismo a problemas filosóficos. Y aún cuando se aplica un enfoque realista, hay una notoria desconexión entre el enfoque de Bernard Williams y los análisis concretos que, hemos de suponer, se hacen bajo el nombre del realismo. Quizá el caso paradigmático es el ya mencionado ensayo de Duncan Bell, que ha de echar mano de la literatura vigente en relaciones internacionales 
para mostrar los límites del cosmopolitismo. En la misma línea, el ensayo que cierra la colección nos da otra señal de la flaqueza del realismo. Para Michael Freeden, el realismo inspirado por Bernard Williams no es tal. A pesar de toda la insistencia en la autonomía de lo político, centrarse en una visión de la legitimidad cuyo pilar es el intercambio de razones vuelve a situar la filosofía política en el moralismo y fuera del ejercicio real de la política. Freeden hace una defensa de una teoría política en diálogo con la ciencia política, totalmente libre de normativismo y, en última instancia, separada de la filosofía política. Lo que nos deja con el interrogante de si el realismo teórico tomado en serio no conduce a la modesta función de asistir la tarea del politólogo. No obstante, dejando a un lado los problemas del realismo como empresa cohesionada, los ensayos aquí reunidos son un magnífico ejercicio de filosofía política y, aunque su unidad viniera dada por un vago parecido de familia, su lectura seguiría siendo valiosa para cualquiera que quiera hacer teoría política analítica en el contexto contemporáneo. 

